\title{
HYDROLOGY FOR LAND-USE PLANNING: THE HILLSIDE AREA, ANCHORAGE, ALASKA
}

OPEN-FILE REPORT 75-105

Prepared by the U.S.Department of the Interior. Geological Survey in cooperation with the Greater Anchorage Area Borough.

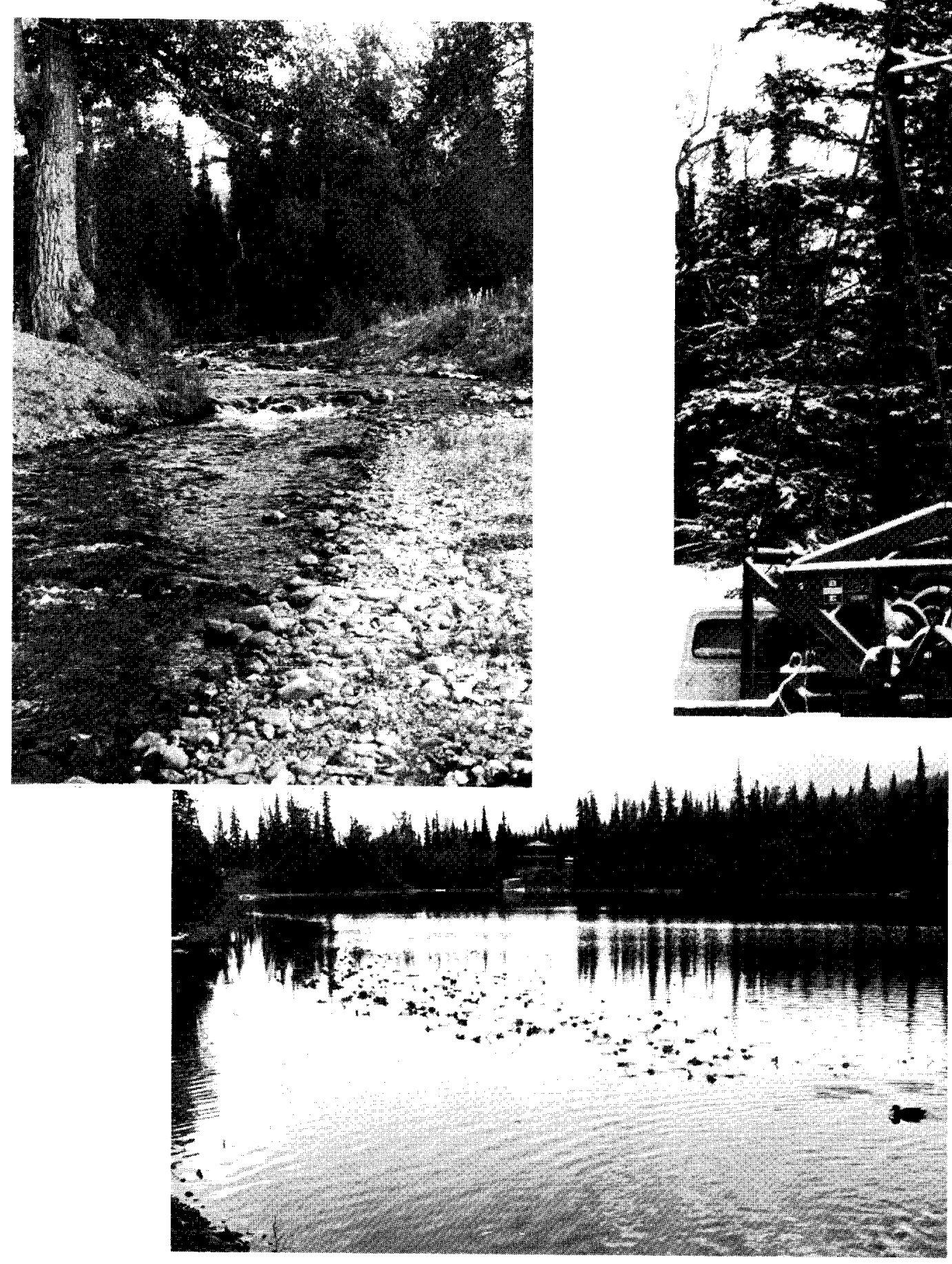

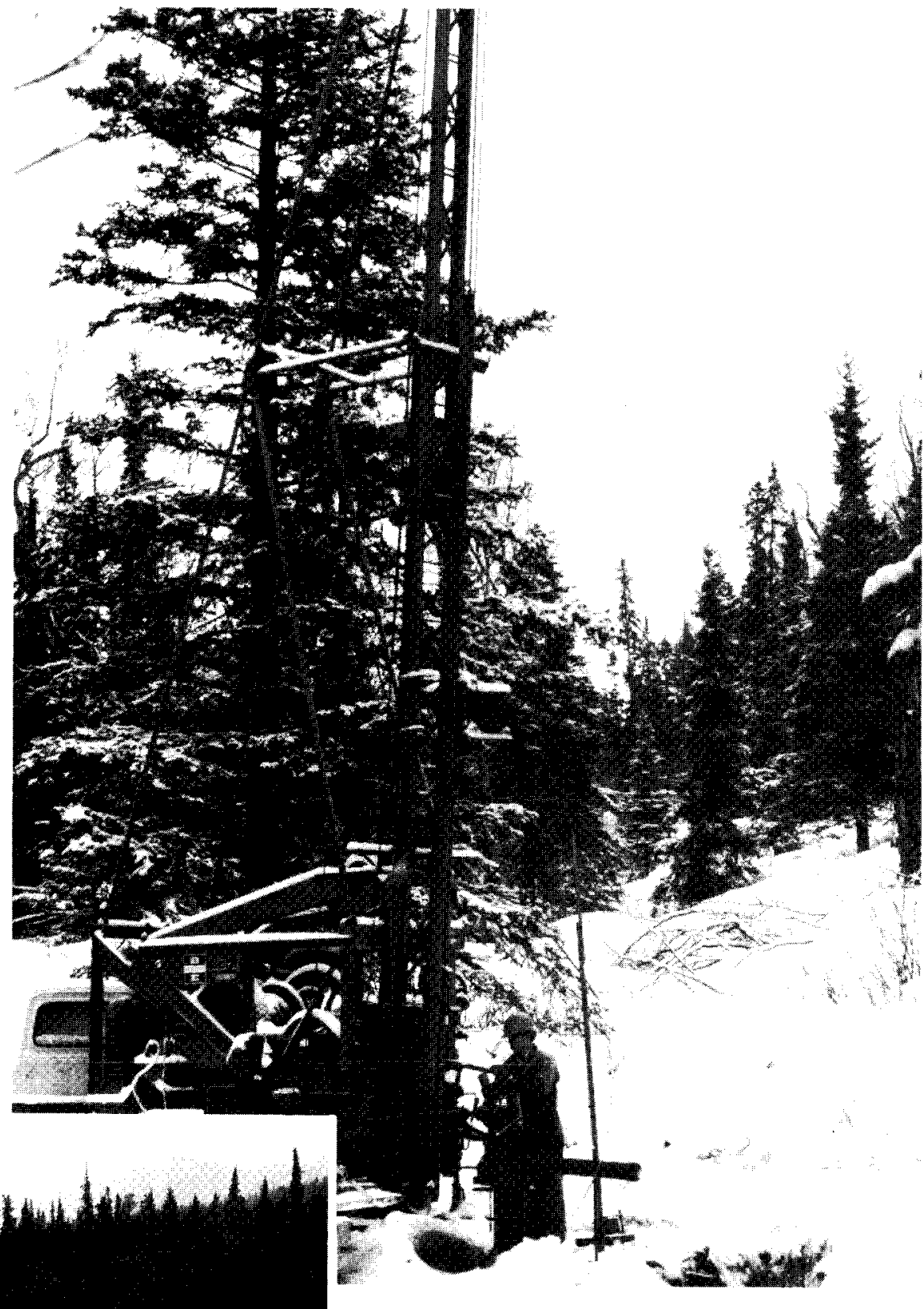

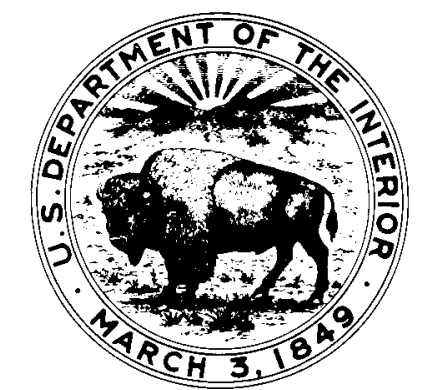




\section{UNITED STATES \\ DEPARTMENT OF THE INTERIOR \\ GEOLOGICAL SURVEY}

Water Resources Division

218 E Street

Anchorage, AK 99501

September 1, 1976

Memorandum

To:

Distribution

From: District Chief, WRD, Anchorage, AK

Subject: PUBLICATIONS - Errata for U.S. Geological Survey

Open-File Report 75-105

Enclosed are errata sheets for Figures 28 and 30 of the subject report "Hydrology for Land-Use Planning: The Hillside Area, Anchorage, Alaska," by L. L. Dearborn and W. K. Barnwell. You may wish to insert them in your copy of the report.

\section{Antronglising}

Enclosures

$$
\begin{aligned}
& \text { TECH. DAAA UNITT } \\
& \text { SEP } 241005 \\
& \text { Elá }
\end{aligned}
$$




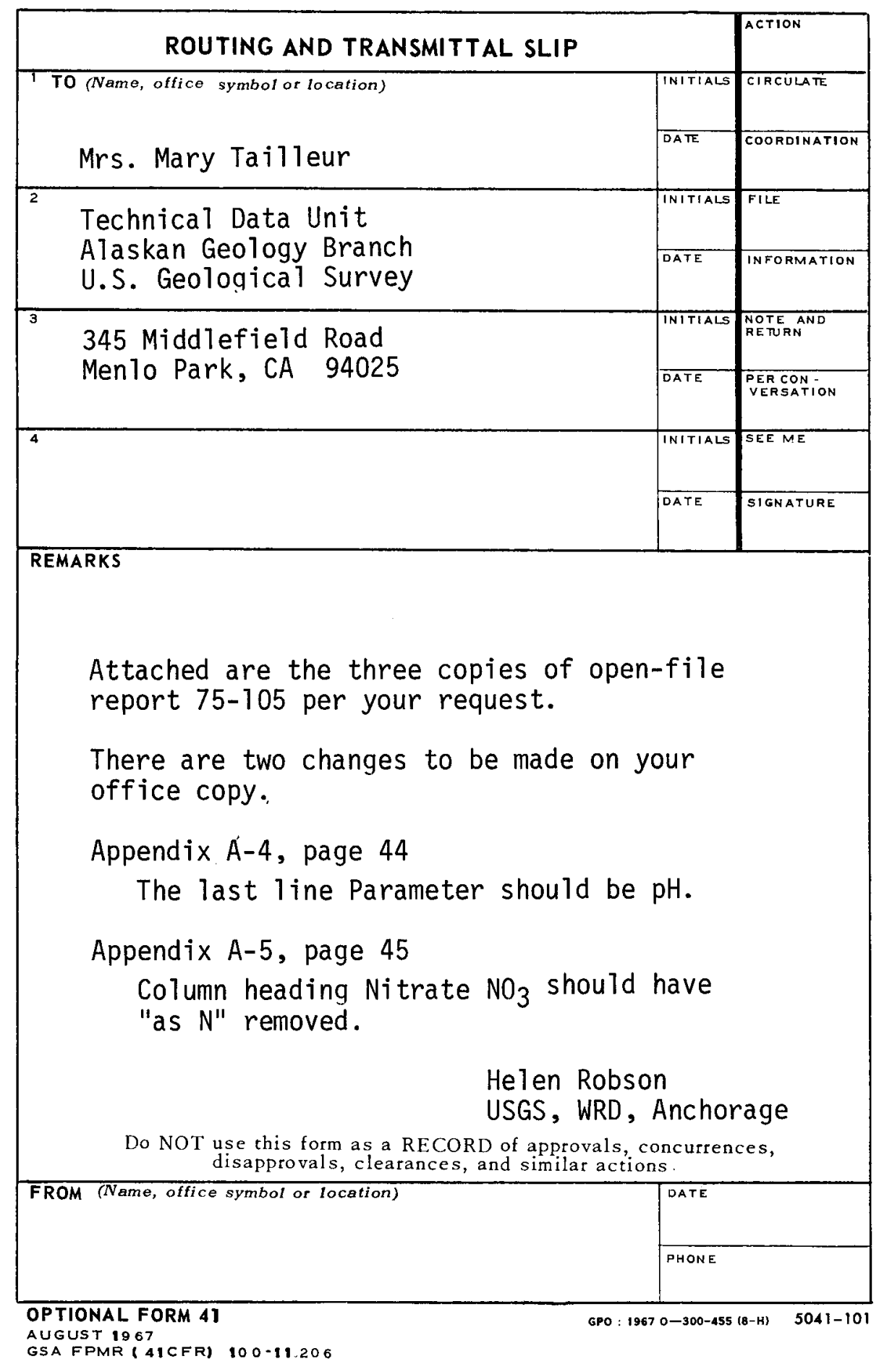




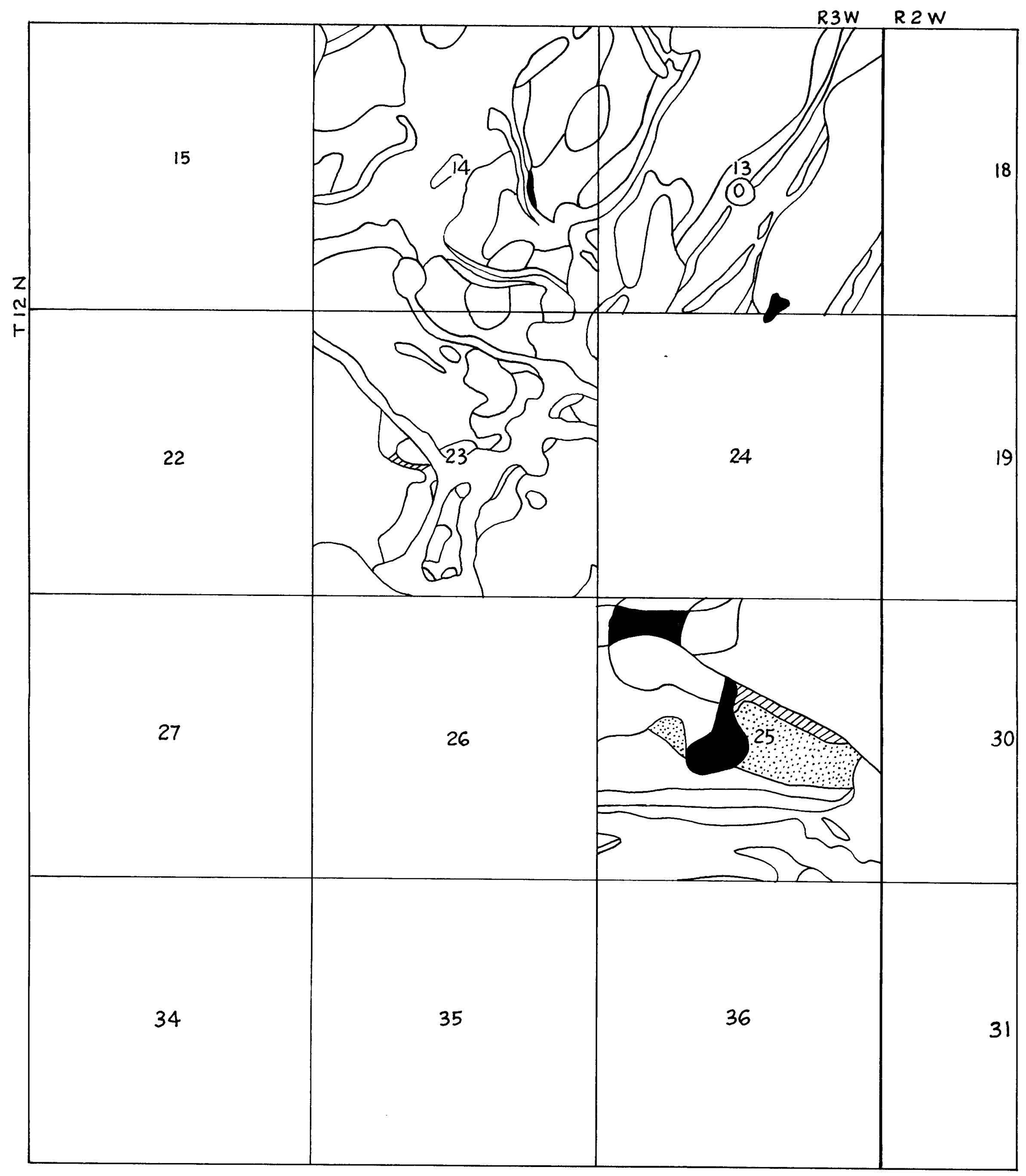

ERRATA

Figure 28.--Relative susceptibility of water resources to pollution by liquid waste disposal. HYDROLOGY FOR LAND-USE PLANNING: THE HILLSIDE AREA, ANCHORAGE, ALASKA

By Larry L. Dearborn and William W. Barnwell

Open-File Report: 75-105, 1975

Changes on page 28 of report.

Relative susceptibility of streams, lakes and shallow ground water to pollution from septictank systems. 


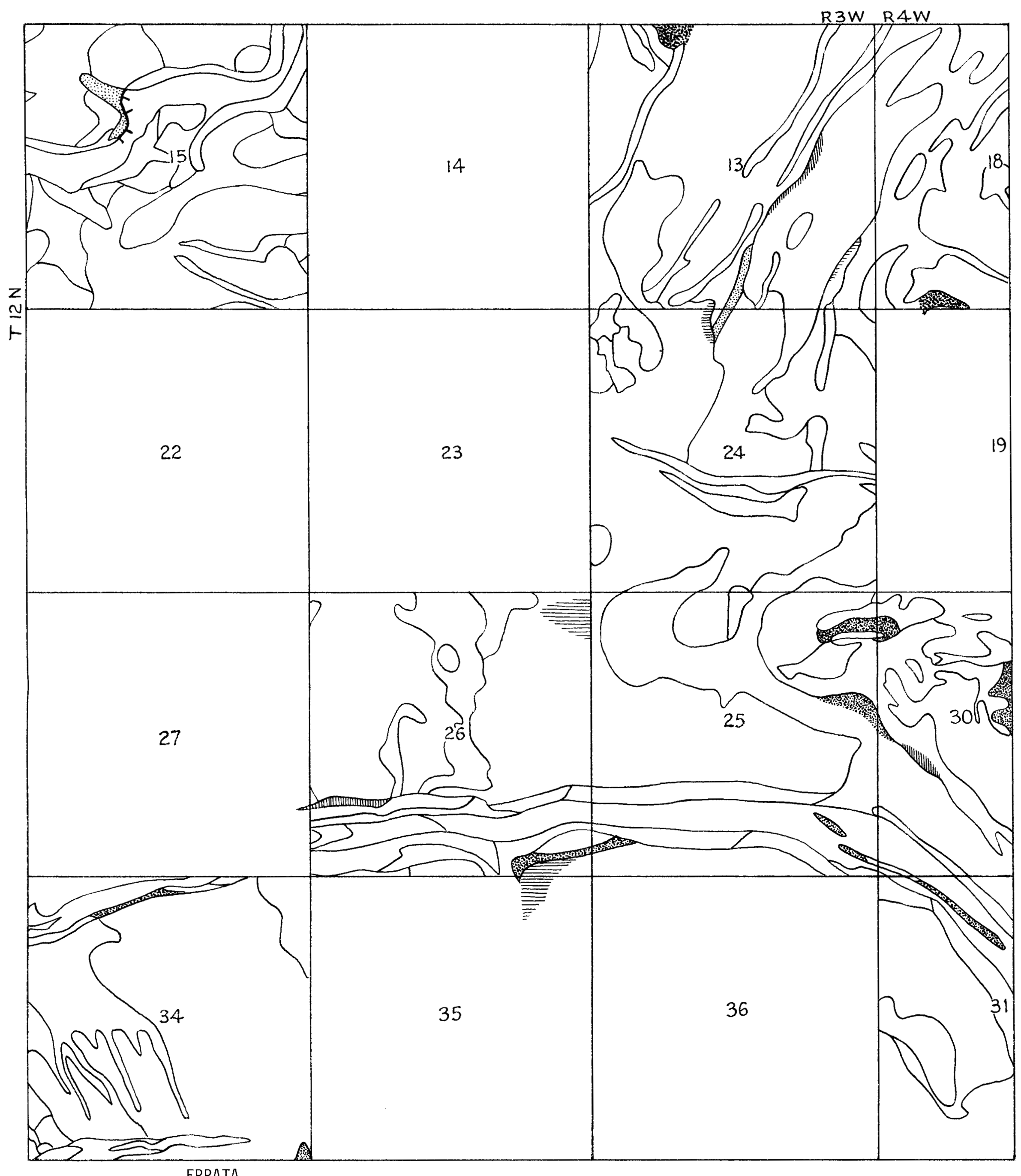

Figure 30.--Generalized landslope and sediment thickness near mountain front. HYDROLOGY FOR LAND-USE PLANNING: THE HILLSIDE AREA, ANCHORAGE, ALASKA

By Larry L. Dearborn and William W. Barnwell

Open-File Report: $75-105,1975$

\section{Changes on page 30 of report}

LANDSLOPE UNITS

Change to light blue--less than 5 percent

Change to lavendar--5-15 percent
Change to dark blue--15-25 percent

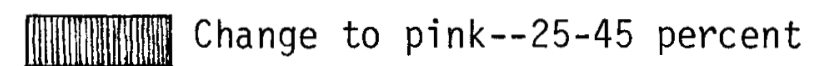


UNITED STATES

DEPARTMENT OF THE INTERIOR

GEOLOGICAL SURVEY

HYDROLOGY FOR LAND-USE PLANNING:

THE HILLSIDE AREA, ANCHORAGE, ALASKA

By

Larry L. Dearborn and William W. Barnwell

Prepared in cooperation with the

Greater Anchorage Area Borough

OPEN-FILE REPORT

75-105

Anchorage, Alaska

1975 


\section{GREATER ANCHORAGE AREA BOROUGH}

3500 EAST TUDOR ROAD

ANCHORAGE, ALASKA 9950

The Hillside area study by the U.S. Geological Survey was made at a critical time during the development of the comprehensive land-use plan and during a time when basic zoning decisions are being made in the Hillside area.

The first major use by the Borough of the findings of this study was in the development of a preliminary comprehensive plan. In preparing this plan, a technique was used whereby four population alternatives were presented to the residents and landowners of the area. These alternatives represented a range from the least amount of development one could realistically expect to the highest degree of development predicted on the basis of population projections. In formulating these alternatives, particularly ones depicting a high degree of development, a number of questions pertaining to hydrologic limitations of the land were raised. For example, what housing density can the land support if the decision is made not to extend sewers and public water into the area? This question can be answered only through knowledge of the area's total water balance, land-drainage characteristics, and the suitability of the land to safely accomodate septic-tank systems. This kind of information is contained in the Hillside report and can be used in current and future planning.

This report clearly demonstrates that a large physiographic area of land must be examined as a unit rather than as a number of small, unrelated parcels. The Hillside is a prime example of an area that is truly interrelated in that any decisions regarding housing density or land use in one part of the community will almost surely have an impact on another.

$$
\text { Wellam H. Beaty }
$$

William H. Beaty

Director of Planning

Greater Anchorage Area Borough 


\section{CONTENTS}

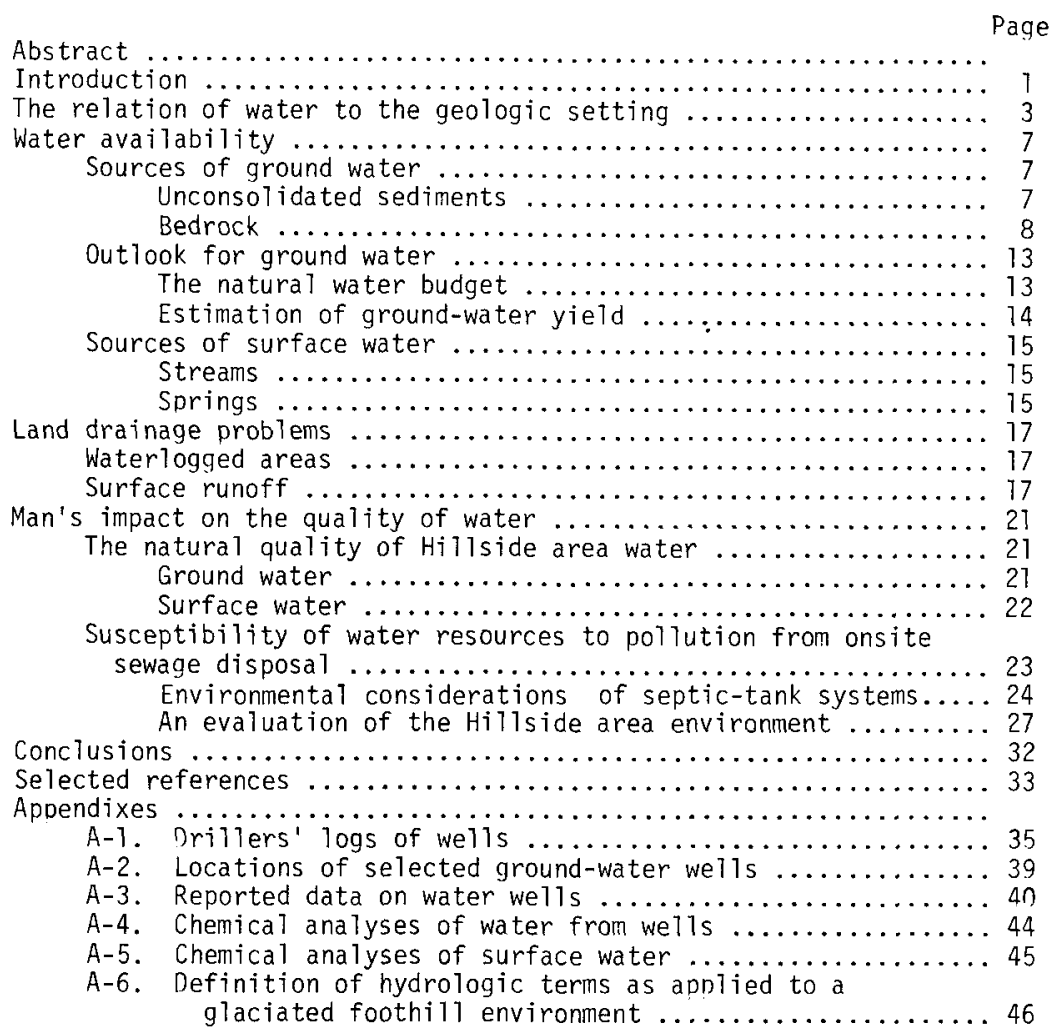

\section{ILLUSTRATIONS}

Frontispiece - Aerial photograph showing 1972 view of Hillside area.

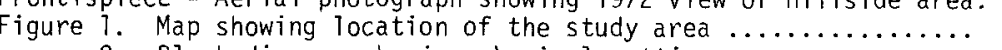
. Block diagram showing physical setting.

. Aerial photographs showing suburban development .......... Photograph showing typical depositional environment at terminus of a large alpine glacier

5. Map showing generalized surficial geology ...............

7-11. Maps showing:

. Thickness of unconsolidated sediments

overlying bedrock ............................. 8
Generalized depth to shailowest domestic-

supply aquifers ...........................
Depth to static water ievel in welis of

(n)...... 11

10. Thickness of saturated sediments and generalized yield of wells $\ldots \ldots \ldots \ldots \ldots \ldots \ldots, 12$

12. Block diagram showing water budget of the area

13. Photograin by sedimentary aquifers $\ldots \ldots \ldots \ldots \ldots \ldots$ in Photograph showing water from springs along a
powerline $\ldots \ldots \ldots 15$

14. Map showing iand drainage

14. Map showing land dra
15. Ground-water seepage crossing road in Upper
Summer drainage and winter icing at Patrick
Road and Upper DeArmoun Road

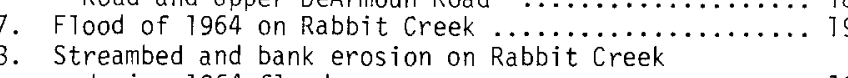
Washout of 0ld Seward Highway roadbed by 1964
......
"ake of the Hills" earth dam after $i 972$

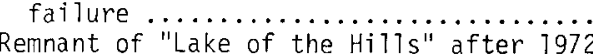
breakout ............................... 20

ILLUSTRATIONS

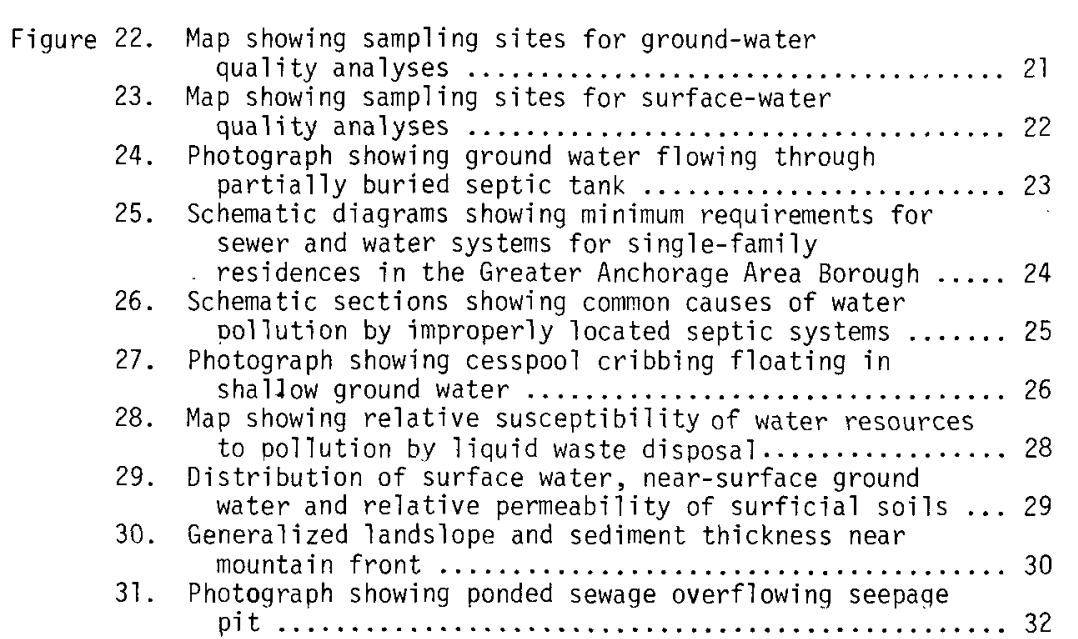

TAB LES

Table 1. Generalized hydrogeologic characteristics of surficial

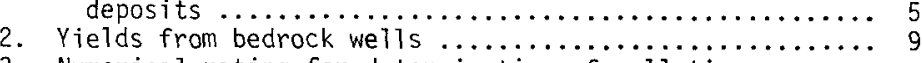

3. Numerical rating for determination of pollution
FACTORS FOR CONVERTING ENGLISH UNITS TO INTERNATIONAL Multiply English units feet $(\mathrm{ft})$
miles $(\mathrm{mi})$

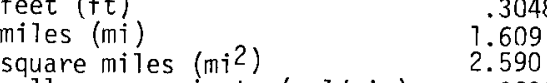
$\begin{array}{ll}\text { gallons Der minute (gal/min) } & .06309 \\ \text { mitition galions per day (Mga7/d) } & .04381\end{array}$

acres
inches inches (in) 25.004047 gaitons (gal) 3.785
To obtain SI units

metres (m)

kilometres $(\mathrm{km})$
square kilometres $\left(\mathrm{km}^{2}\right)$ litres per second ( $1 / \mathrm{s})$ cubic metres per second $\left(\mathrm{m}^{3} / \mathrm{s}\right)$ square kilometres $\left(\mathrm{km}^{2}\right)$ millimetres (mm)

er second $\left(\mathrm{m}^{3} / \mathrm{s}\right)$
itres $(1)$

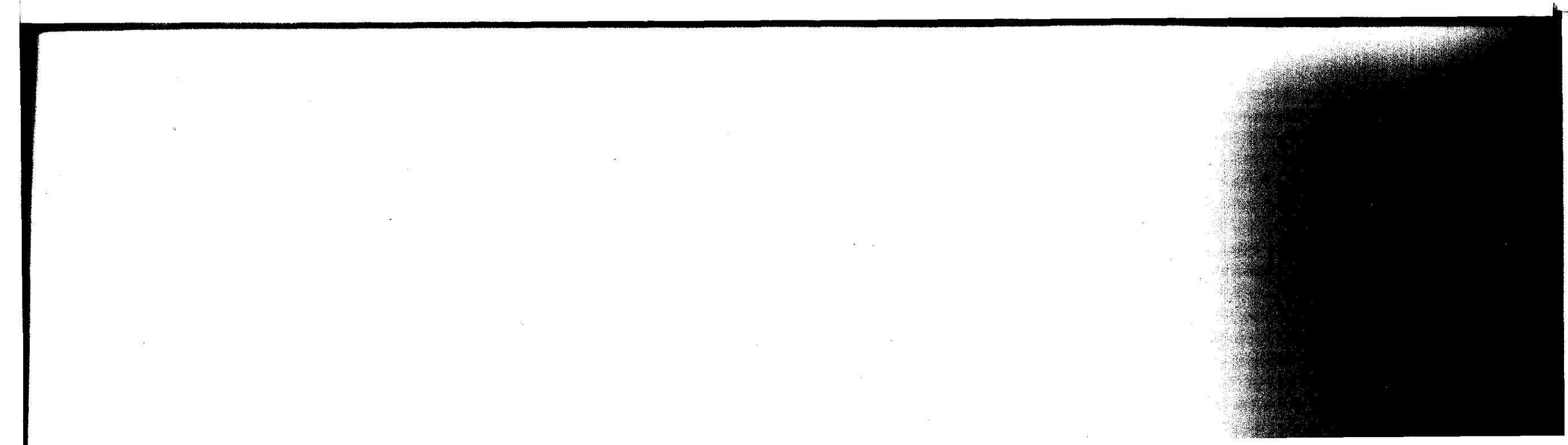




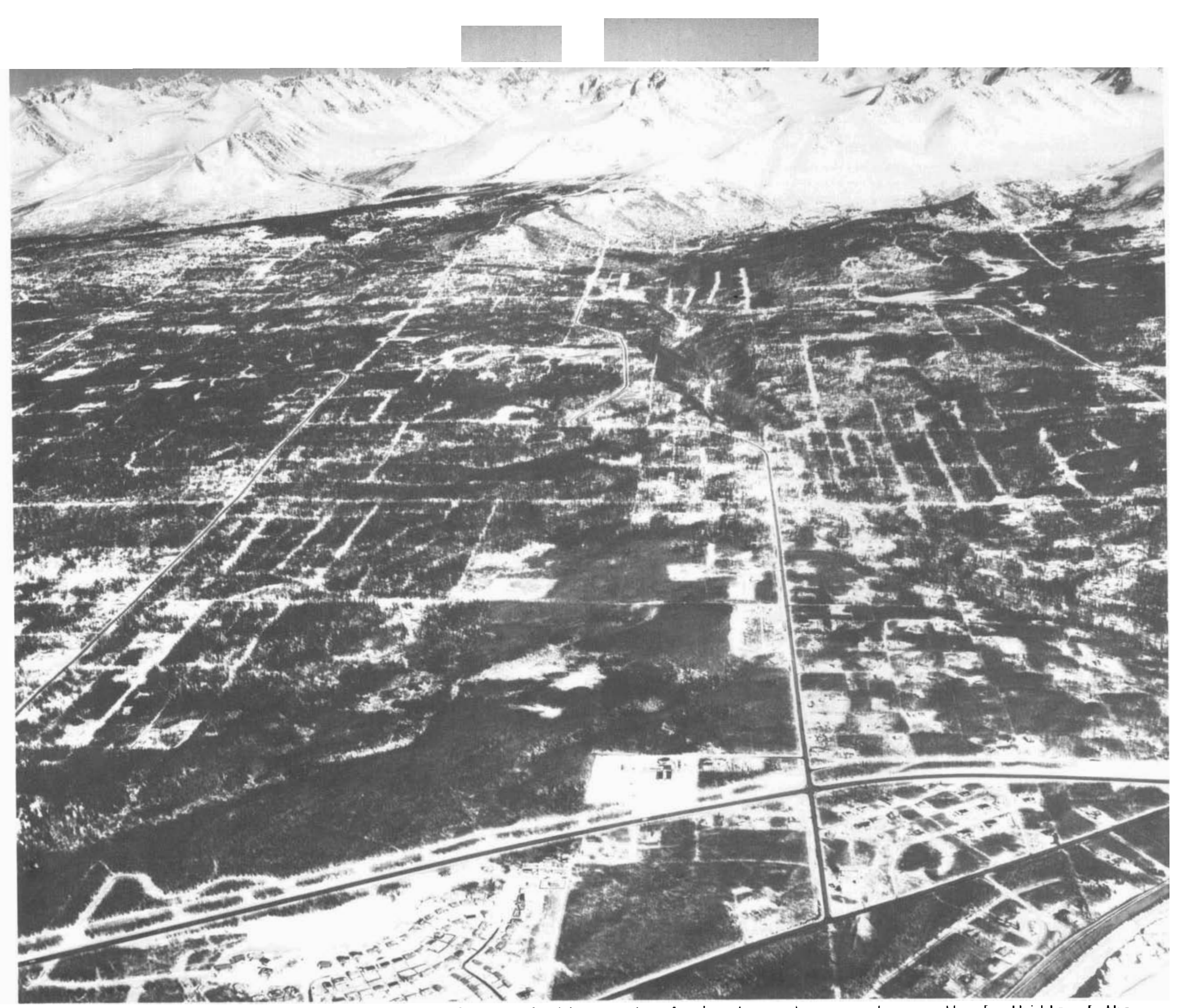

Frontispiece.- 1972 aerial view of the Hillside area looking east. As development encroaches on the foothills of the Chugach Mountains, water supply, drainage, and waste disposal may become critical problems.

\section{ABSTRACT}

Rapid residential growth of the Hillside area, Anchorage, Alaska, may cause depletion of aquifers and a change in quality of water resources as a result of extensive development of small-lot tracts. Ground-water yields are low and may be locally inadequate for single family requirements where wells produce from bedrock in the eastern Hillside region. At lower altitudes single family water requirements of 3 to 10 gallons per minute or 0.2 to 0.6 litre per second usually can be obtained, but aquifers capable of being pumped at larger yields for public supplies are uncommon. However, in a few localities, wells do produce 40 to 300 gallons per minute or 2.5 to 19 litres per second from sand and gravel aquifers lying within thick sequences of glacial till. Streamflow within the Hillside area is inadequate as a significant source of water for public supply. Springs, swamps, and water-logged surficial sediments in the Hillside area are mainly caused by hilly terrain and low permeability of surficial materials.

The relative vulnerability of streams, lakes, and ground water to pollution caused by the discharge of liquid waste, particularly from onsite sewage-disposal systems, is moderate to high in about half the study area. At higher altitudes contamination of bedrock aquifers may occur if discharge of liquid wastes is not regulated. The deep sedimentary aquifers at lower altitudes are less susceptible to contamination. However, shallow groundwater bodies may become polluted by discharge of sewage effluent and, consequently, some deep wells may be contaminated by seepage down the outside of casings or through leaky casing joints and underground seals. 


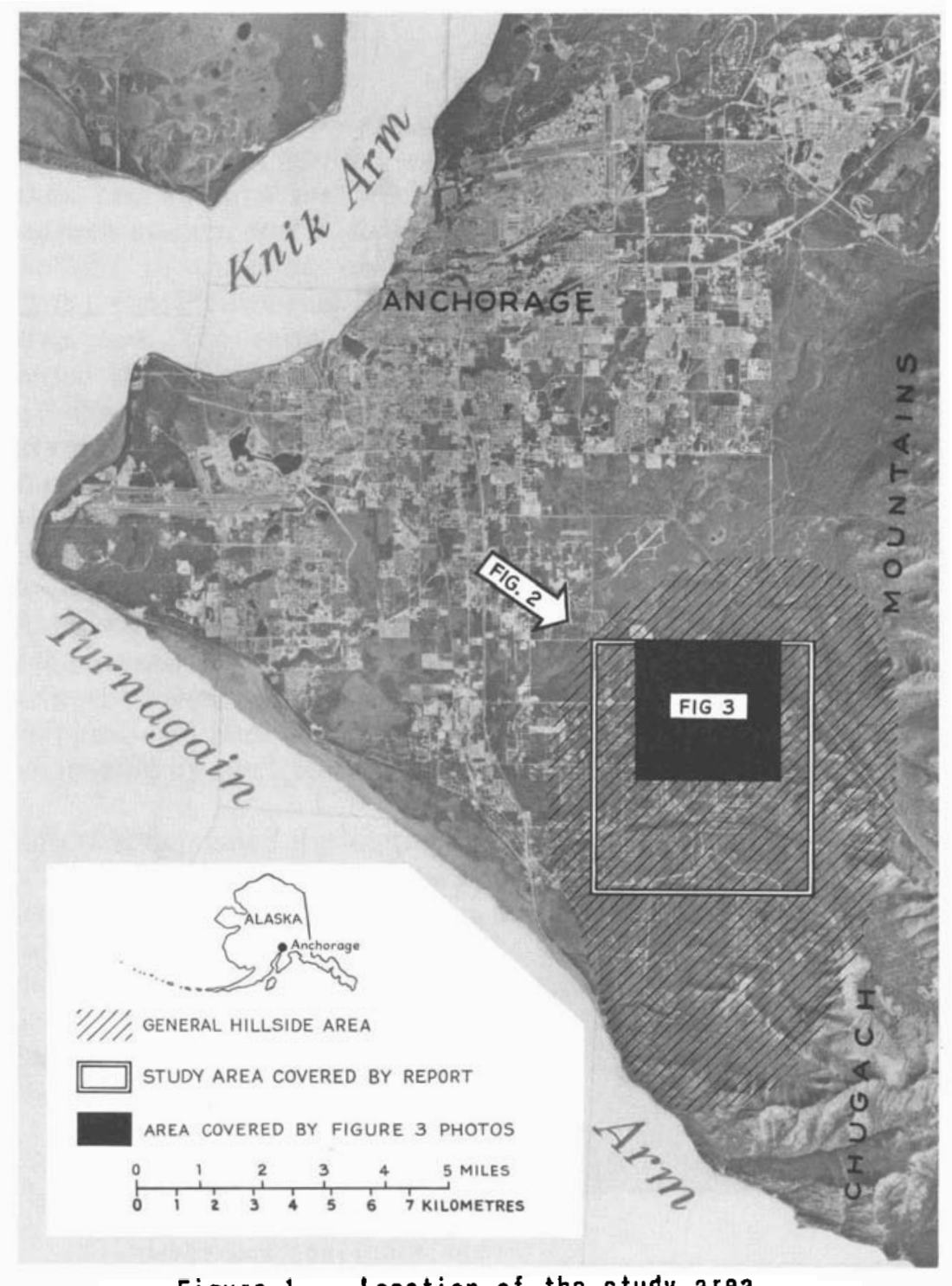

Figure 1.-- Location of the study area.

\section{INTRODUCTION}

This report describes the hydrology of an area locally known as the Hillside area, a rapidly growing suburban community about 8 mi $(13 \mathrm{~km})$ southeast of the city of Anchorage (fig. 1). The general Hillside area consists of westward-sloping land that is bordered by Turnagain Arm on the south and west and by the Chugach Mountains on the east (fig. 2). The area is currently being subdivided into residential lots. According to the Greater Anchorage Area Borough, the population of the Hillside area may reach 15,000 people by 1985 , or approximately three times its current population (Paul Carr, oral commun. 1973). A perspective on the impact of the current rate of development in the area can be gained from aerial photographs (fig. 3) which show the intensity of subdivision growth from 1965 to 1974.

The Greater Anchorage Area Borough, faced with long-range water and land-management decisions, requested that the U.S. Geological Survey study the water situation of the Hillside area as part of an ongoing cooperative program. The study began in 1971 with the following objectives:

1. To determine the water-supply potential within the Hillside area.

2. To define existing or potential drainage problems related to land development.

3. To determine the susceptibility of the water resources to pollution by liquid-waste disposal.

The study consisted largely of a literature search, compilation, and interpretation of existing data. The study was concentrated within the $14 \mathrm{mi}^{2}\left(36.3 \mathrm{~km}^{2}\right)$ shown in figures 1 and 2 . This report presents an interpretation of the current information on water resources.

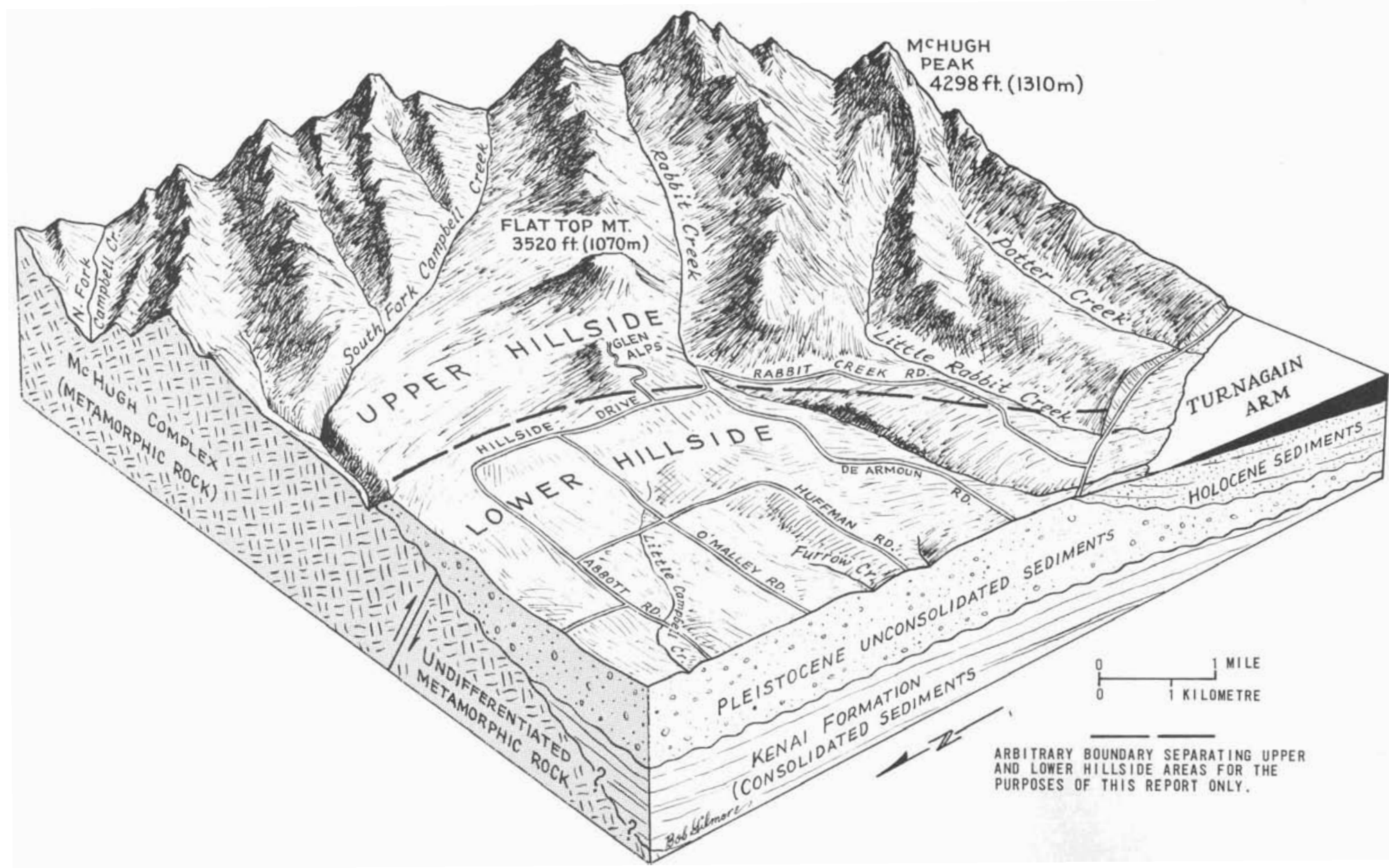

Figure 2.-- Block diagram of the Hillside area showing physical setting, viewed looking southeast from Spenard. 

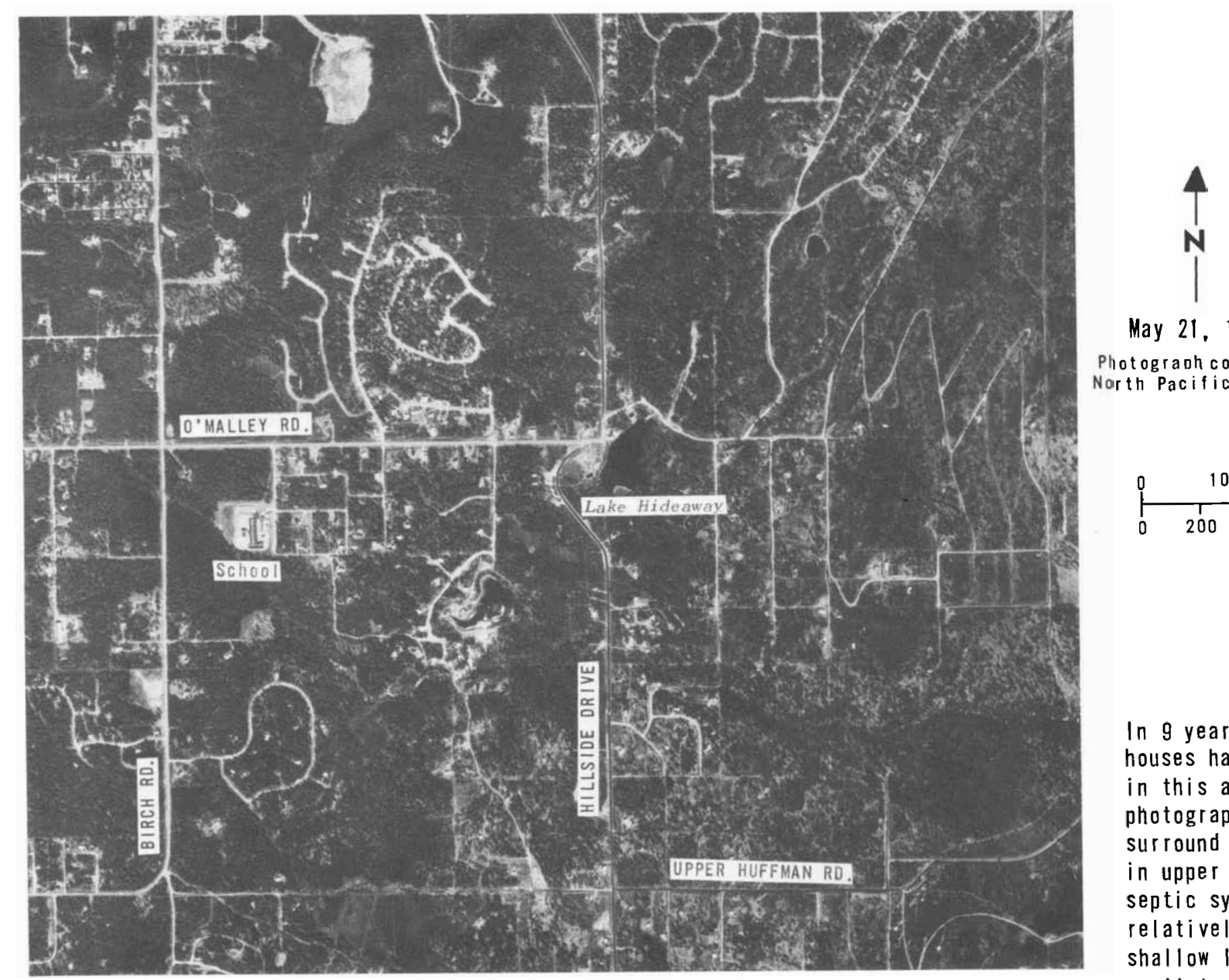

May 21,1974

Phot ograob courtesy of North Pacific Aerial Surveys Inc.

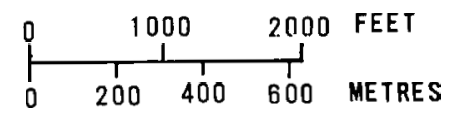

In 9 years the density of houses has more than tripled in this area. In lower photograph very few homes surround Lake Hideaway: in upper photograph many septic systems are located

relatively close to the shallow lake. Continued small-tract development where springs and seeps are common will add to the potential for serious drainage problems. An altitude drop of approximately $1000 \mathrm{ft}(300 \mathrm{~m})$ from east to west further complicates most modifications of natural runoff.

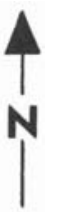

May 16,1965

Photograph courtesy of

Air Photo Tech Inc.

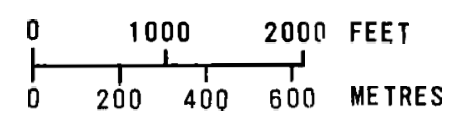




\section{THE RELATION OF WATER \\ TO THE GEOLOGIC SETTING}

The availability of ground water and the distribution of streams, lakes, and swamps are largely the result of glacial processes. The bedrock and unconsolidated sediments of the Anchorage plain and foothills to the east were covered by several glacial advances during the Pleistocene Epoch, from 10,000 to about 2 million years ago. The early Pleistocene glacial ice masses repeatedly buried the Hillside area to an altitude of at least $3,300 \mathrm{ft}(1,000$ $\mathrm{m})$ above the present sea level. During the last major glacia advance (Wisconsin), about 20,000 years ago, ice flowed southward through the Upper Cook Inlet basin and covered the Anchorage plain and foothills to an altitude of about $800 \mathrm{ft}(240$ $\mathrm{m})$. This southward-flowing ice mass was joined by a glacier flowing west through Turnagain Arm. The two ice masses coalesced in the vicinity of what is now Huffman Road. During this advance, bedrock and older unconsolidated marine and glacial sediments were scoured by the erosive force of moving ice and redeposited. Sediments that were not eroded were tightly compacted by the tremendous weight of the ice mass.

Materials deposited during the Wisconsin Glaciation make up most of the surficial sediments in the Hillside area. The composition and distribution of the glacier-related deposits vary greatly with depth and lateral distance (figs. 4, 5, and 6). Most of the unconsolidated glacial sediments contain poorly sorted rock particles ranging in size from clay to boulders and have low permeability. These deposits are commonly called till.
During and following the retreat of the Wisconsin ice mass, melt-water streams moved great quantities of detrital material. In part, the modern topography and surface drainage of the Hillside area are a direct result of flow in melt-water runoff channels that bordered glacial lobes or issued from glacier termini as the ice mass retreated. The streams flowing through the area today occupy some of these relatively young alluvial channels.

The thick and extensive morainal deposits (see fig. 5 and table 1) apparently resisted erosion by melt-water runoff. Few drainage channels cross the moraines, and swamps and ponds are scattered among the hummocks and low hills of the morainal areas.

Subsurface deposits composed of stream-laid sand and gravel are of great hydrologic significance to the area. They yield most of the ground water pumped by wells. These deposits lie within and between till layers.

Older basement rocks, or bedrock, underlie the unconsolidated deposits or are exposed locally in the easternmost part of the Hillside area. The bedrock consists of conglomerate, limestone, silty sandstone, argillite, and volcanic rocks. Generally, these rocks are metamorphosed and are hard and dense except where extensively fractured or weathered at their contact with overlying sediments or at the land surface.

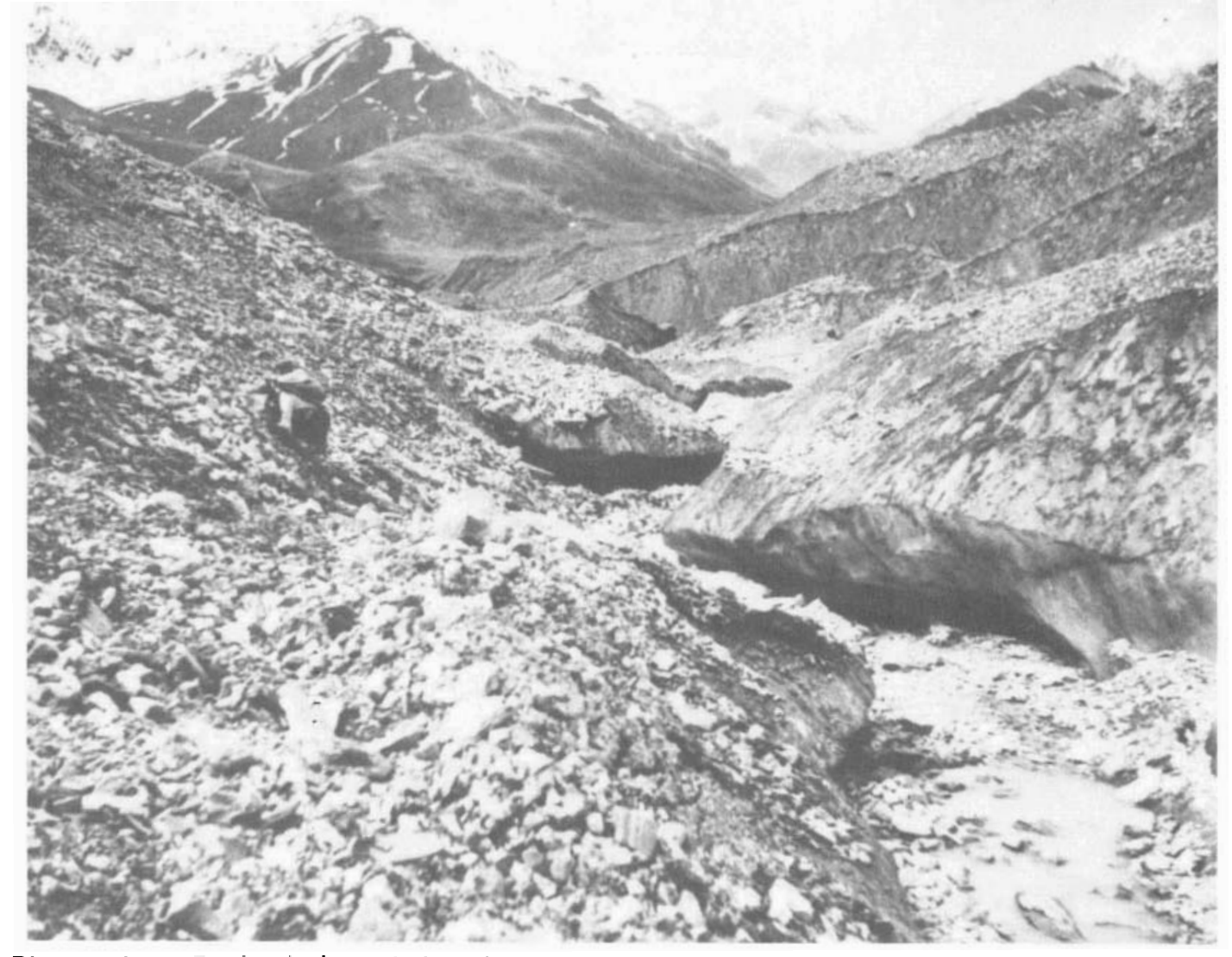

Figure 4.-- Typical depositional environment at terminus of large alpine glacier.

Rock fragments deposited directly from melting ice are angular and have a wide range in fragment size. However, in outwash streams silt and clay particles are washed from the mixed materials and the anguiar fragments are rounded to form gravel. Typically, in the subsurface these streamlaid deposits form long narrow beds of permeable sand and gravel, which yield water to wells. 


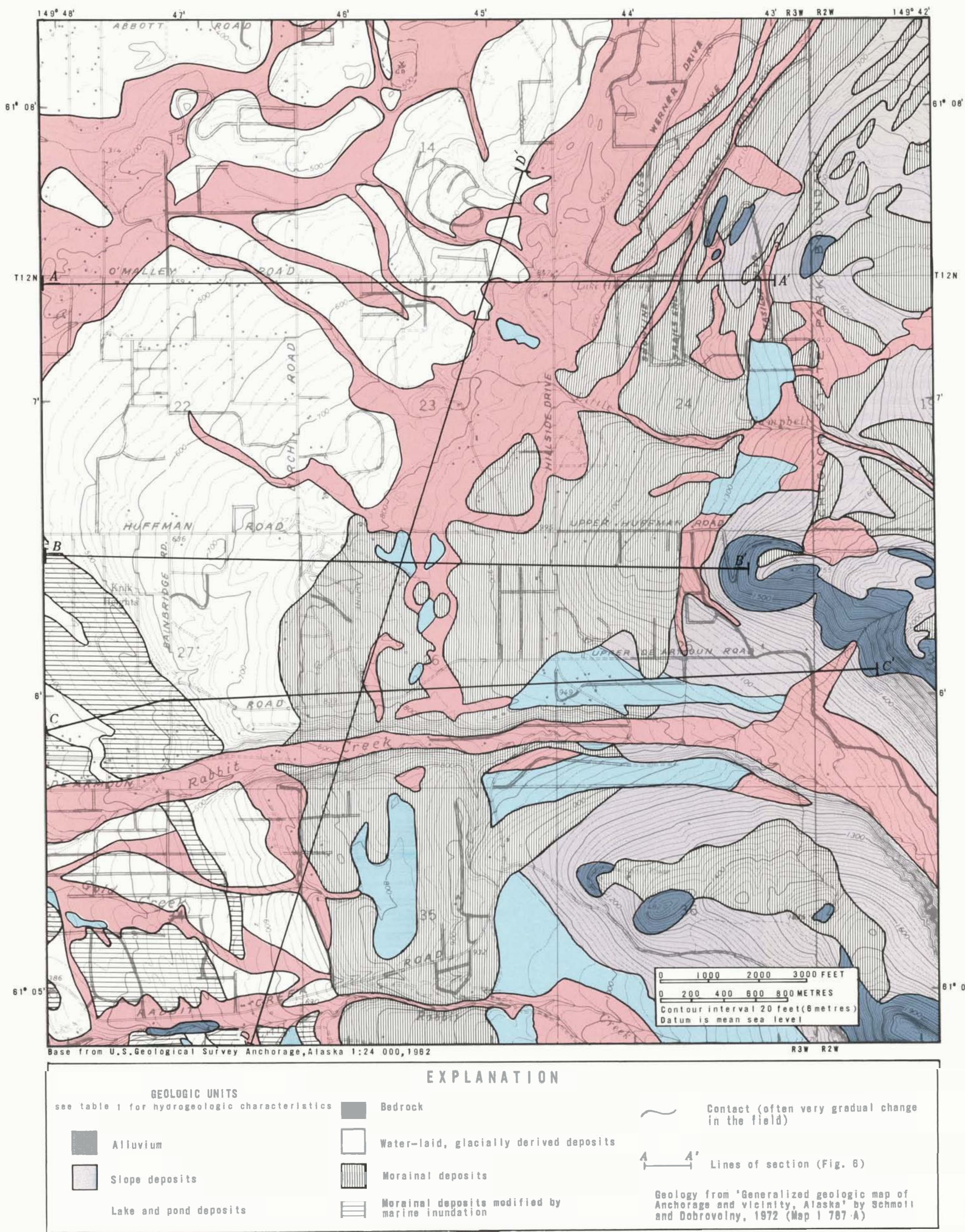

Figure 5.-- Generalized surficial geology of the Hillside area. 
Table 1.-- Generalized hydrogeologic characteristics of surficial deposits.

(See figure 5 for map of surficial deposits).

\begin{tabular}{|c|c|c|c|c|c|c|c|}
\hline Geologic unit & Geologic materiat & $\begin{array}{l}\text { Topouraphic expres- } \\
\text { sion }\end{array}$ & Distribution & $\begin{array}{l}\text { Surficial drainage, } \\
\text { infiltration and } \\
\text { permeability }\end{array}$ & Water content & $\begin{array}{l}\text { Water-yielding } \\
\text { capability }\end{array}$ & $\begin{array}{l}\text { Hydrologic character- } \\
\text { istics retated to to } \\
\text { ifquid waste dtspesal }\end{array}$ \\
\hline Alluvium & 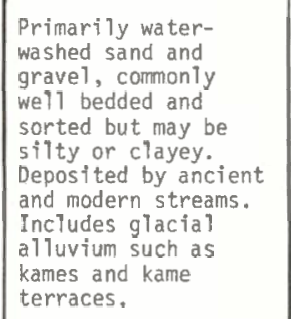 & $\begin{array}{l}\text { Modern and abandoned } \\
\text { stream channels } \\
\text { with } 71 \text { thte relief. } \\
\text { Alluvial fans and } \\
\text { kame terraces above } \\
\text { 1, } 100 \text { feet altitudede } \\
\text { with steeper smooth } \\
\text { slopes. }\end{array}$ & $\begin{array}{l}\text { Widespread through- } \\
\text { out the area; ex- } \\
\text { tensive deposits in } \\
\text { Little Campbel1 } \\
\text { Creek valley below } \\
\text { 900 feet altitide } \\
\text { and in Rabbit Creek } \\
\text { and upper Litte } \\
\text { Rabbit Creek vaileys. }\end{array}$ & $\begin{array}{l}\text { Low runoff, rapid } \\
\text { infiltration and } \\
\text { relatively high } \\
\text { permeabifity except } \\
\text { where sitt is abun- } \\
\text { dant. Rapid move- } \\
\text { ment of water into } \\
\text { and through this } \\
\text { unnt recharges } \\
\text { shallow and perhaps } \\
\text { deep aquifers. }\end{array}$ & $\begin{array}{l}\text { Commoniy saturated } \\
10 \text { to } 20 \text { feet be- } \\
\text { low the surface, par- } \\
\text { ticularly along } \\
\text { strean channels. } \\
\text { Discontinuous perched } \\
\text { water bodies may } \\
\text { exist at shatlower } \\
\text { depths. }\end{array}$ & $\begin{array}{l}\text { Fair to good. Shal- } \\
\text { low wells may yield } \\
\text { lo-50 gal/min where } \\
\text { saturated thickness } \\
\text { of unit exceeds } 10 \\
\text { feet. }\end{array}$ & $\begin{array}{l}\text { Generally has adequ- } \\
\text { ate percolation cap- } \\
\text { acity. However, } \\
\text { percoiation rate in } \\
\text { some permeable depo- } \\
\text { sits may be too rapid } \\
\text { to allow adequate } \\
\text { attenuatton of con- } \\
\text { taminants in distances } \\
\text { Tess than } 300 \text { feet. }\end{array}$ \\
\hline Slope deposits & $\begin{array}{l}\text { Intermixed deposits } \\
\text { of fresh and weather- } \\
\text { ed bedrock fragments } \\
\text { and reworked glacial } \\
\text { drift which contains } \\
\text { clean and welT-sorted } \\
\text { or dirty sand and } \\
\text { graveT. }\end{array}$ & $\begin{array}{l}\text { Rather smooth } \\
\text { siopes of talus fans } \\
\text { and cones near bed- } \\
\text { rock exposures. } \\
\text { Somewhat gentler } \\
\text { slopes toward down- } \\
\text { hill boundary. } \\
\text { Steep valley slopes } \\
\text { along major streams. }\end{array}$ & $\begin{array}{l}\text { Common on steep } \\
\text { hil1sides above } \\
1,000 \text { feet altitude } \\
\text { and along steeper } \\
\text { val7ey walls. Thin } \\
\text { deposits downs lope } \\
\text { from bedrock outcrops } \\
\text { common. }\end{array}$ & $\begin{array}{l}\text { Where loosely com- } \\
\text { pacted, littie run- } \\
\text { off, rapid infir- } \\
\text { tration and high } \\
\text { permeability; allow- } \\
\text { ing rapid vertica? } \\
\text { flow through mate- } \\
\text { rials. At high } \\
\text { altitudes, important } \\
\text { to recharge of lower- } \\
\text { altitude aquifers. }\end{array}$ & $\begin{array}{l}\text { Typically unsaturated } \\
\text { except for short per- } \\
\text { ids after heavy } \\
\text { rains. }\end{array}$ & $\begin{array}{l}\text { Poor. Usual1y wi11 } \\
\text { not yieeld a signi- } \\
\text { ficant supply of } \\
\text { water due to spora- } \\
\text { dic saturation and } \\
\text { thinness of unit. }\end{array}$ & $\begin{array}{l}\text { Percolation rates are } \\
\text { rapid and contamin- } \\
\text { ants may not be adequ- } \\
\text { ately attenuated } \\
\text { before Tiquid reaches } \\
\text { fractured bedrock or } \\
\text { shallow water in } \\
\text { underiying material. }\end{array}$ \\
\hline $\begin{array}{l}\text { Lake and pond } \\
\text { deposits }\end{array}$ & $\begin{array}{l}\text { Thin to thick deposits } \\
\text { of silt and clay with } \\
\text { some interbedded fine } \\
\text { sand and local1y } \\
\text { thin gravel beds. } \\
\text { Formed where mountain } \\
\text { streams were darmed } \\
\text { by glacial ice or } \\
\text { Tateral moraines. }\end{array}$ & $\begin{array}{l}\text { Smooth gentle slopes } \\
\text { of former lake bottorn } \\
\text { surfaces. Locally } \\
\text { dissected by modern } \\
\text { streams. }\end{array}$ & $\begin{array}{l}\text { Primarily deposited } \\
\text { where 7and surface } \\
\text { exceeds } 800 \text { feet } \\
\text { altitude and f7anking } \\
\text { stream val1eys or at } \\
\text { the heads of minor } \\
\text { drainages. }\end{array}$ & 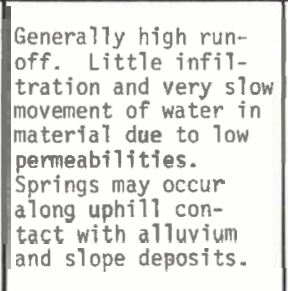 & $\begin{array}{l}\text { May be saturated at } \\
\text { or near the surface } \\
\text { but probably unsat- } \\
\text { urated at greater } \\
\text { depths. }\end{array}$ & $\begin{array}{l}\text { Poor. However, ex- } \\
\text { caavations usually } \\
\text { filly with water due } \\
\text { to a slow constant } \\
\text { seepage of water } \\
\text { near the surface. }\end{array}$ & $\begin{array}{l}\text { Percolation rates } \\
\text { very low. Where unit } \\
\text { is not penetrated, } \\
\text { liquid wastes will } \\
\text { eventually pond at } \\
\text { the surface. }\end{array}$ \\
\hline $\begin{array}{l}\text { water-laid } \\
\text { glaciatly de- } \\
\text { rived deposits }\end{array}$ & $\begin{array}{l}\text { Primarily interbedded } \\
\text { fine sand and clay } \\
\text { with some gravel and } \\
\text { cobbles. Commonly } \\
\text { gradational to other } \\
\text { deposits. }\end{array}$ & $\begin{array}{l}\text { Broad, smooth to } \\
\text { slighty hummocky } \\
\text { prain with nearly } \\
\text { constant slope; little } \\
\text { relfef and poorly } \\
\text { developed drainage. }\end{array}$ & $\begin{array}{l}\text { Restricted to western } \\
\text { part of map area be- } \\
\text { Tow } 800 \text { feet altitude } \\
\text { Widespread in Little } \\
\text { Campbel1 Creek basin. }\end{array}$ & $\begin{array}{l}\text { Commonity runoff is } \\
\text { moderate, infiltra- } \\
\text { tion low to moderate, } \\
\text { and permeabi } 1 \text { aty } \\
\text { varies from very low, } \\
\text { to moderate; localyy, } \\
\text { higher water absorp- } \\
\text { tion and conduction } \\
\text { rates exist in } \\
\text { sandy material. }\end{array}$ & $\begin{array}{l}\text { Mostly unsaturated, } \\
\text { except generally } \\
\text { saturated along } \\
\text { drainages. }\end{array}$ & $\begin{array}{l}\text { Generally poor. Unit } \\
\text { is either too thin } \\
\text { or is not saturated. }\end{array}$ & $\begin{array}{l}\text { Generally fair. Per- } \\
\text { colation character- } \\
\text { istics not adequate } \\
\text { where high silt or } \\
\text { clay content is } \\
\text { present. }\end{array}$ \\
\hline $\begin{array}{l}\text { Morainal } \\
\text { deposits }\end{array}$ & $\begin{array}{l}\text { Wel1-mixed deposits } \\
\text { of fragnented rock } \\
\text { that contain renses } \\
\text { of poorly sorted } \\
\text { sand and gravel } \\
\text { directly deposited } \\
\text { by ice. }\end{array}$ & $\begin{array}{l}\text { Elongated slopes } \\
\text { or crested hills or } \\
\text { ridges with genera11y } \\
\text { smooth topography; } \\
\text { some iocal rounded } \\
\text { mounds. }\end{array}$ & $\begin{array}{l}\text { Mostly within lat- } \\
\text { eral moraine belt } \\
\text { that descends in } \\
\text { altitude from } 900- \\
7,300 \text { feet in the } \\
\text { north to } 700-1,000 \\
\text { feet in the south, } \\
\text { paratlet to the moun- } \\
\text { tain front. Remnants } \\
\text { of ofder moraines } \\
\text { scattered at higher } \\
\text { altitudes. }\end{array}$ & $\begin{array}{l}\text { Infiltration rates } \\
\text { and permeability } \\
\text { are commonly moderate: } \\
\text { however locally steep } \\
\text { Tandslopes cause most } \\
\text { water to run off. } \\
\text { Where compacted or } \\
\text { contains much clay, } \\
\text { water does not infit- } \\
\text { trate and ponds in } \\
\text { depressions. }\end{array}$ & $\begin{array}{l}\text { Commoniy saturated } \\
\text { at considerable } \\
\text { depth in deposits } \\
\text { thicker than } 50 \text { feet. } \\
\text { Perched water may } \\
\text { exist at shallow } \\
\text { depth during wet } \\
\text { seasons. }\end{array}$ & $\begin{array}{l}\text { Good to poor. Ordin- } \\
\text { arify does not yield } \\
\text { singificant quant- } \\
\text { itties of water to } \\
\text { wells or excavation. } \\
\text { However, saturated } \\
\text { sand and gravel len- } \\
\text { ses, where present, } \\
\text { cormony } 1 y \text { yield } 5 \text { to } \\
20 \text { gal/min. }\end{array}$ & $\begin{array}{l}\text { Percolation rates } \\
\text { adequate except where } \\
\text { hardpan perches per- } \\
\text { colating liquids at } \\
\text { shallow depths. }\end{array}$ \\
\hline $\begin{array}{l}\text { Morainal depo- } \\
\text { sits modified } \\
\text { by marine in- } \\
\text { undation }\end{array}$ & $\begin{array}{l}\text { Mixture of silt, } \\
\text { sand, gravei, cob- } \\
\text { bles and boulders } \\
\text { of glacia origin } \\
\text { and reworked by } \\
\text { marine waters. Com- } \\
\text { monly contains or } \\
\text { is overlain by beds } \\
\text { of sift, sand and } \\
\text { gravel. sand }\end{array}$ & $\begin{array}{l}\text { Paral1e1, narrow- } \\
\text { crested, northwest- } \\
\text { trending ridges } \\
\text { with low relief. }\end{array}$ & $\begin{array}{l}\text { General1y below } 700 \\
\text { feet altititude and } \\
\text { restricted to south- } \\
\text { west part of map } \\
\text { area. }\end{array}$ & 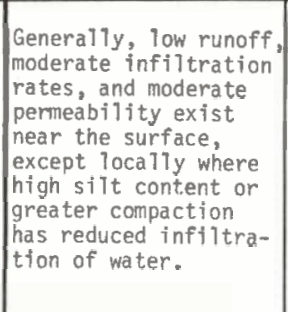 & $\begin{array}{l}\text { Mostly unsaturated } \\
\text { except where siitt } \\
\text { beds at shallow } \\
\text { depths have caused } \\
\text { bogs to develop in } \\
\text { depressions. }\end{array}$ & $\begin{array}{l}\text { Generaily poor. Unit } \\
\text { is either too thin } \\
\text { or is not saturated. }\end{array}$ & $\begin{array}{l}\text { Percolation rates } \\
\text { fair except poor in } \\
\text { localities of high } \\
\text { sediment compaction } \\
\text { and/or high silt } \\
\text { content. }\end{array}$ \\
\hline Bedrock & $\begin{array}{l}\text { Weak7y metamorphosed } \\
\text { siltstone, graywacke, } \\
\text { arkose, conglomeratic } \\
\text { sandstone and cherty } \\
\text { greenstone, associat- } \\
\text { ed with argil1ite. } \\
\text { Near Rabbit Creek, } \\
\text { Timestone, marble, } \\
\text { greenstone and cherty } \\
\text { argilite (Ciark, } \\
\text { 1973). }\end{array}$ & $\begin{array}{l}\text { Steep-sided ridges } \\
\text { and knobs. }\end{array}$ & $\begin{array}{l}\text { Exposed on } 7 y \text { on } \\
\text { steepest sTopes and } \\
\text { some ridge crests } \\
\text { above } 7,000 \text { feet } \\
\text { altitude. In places } \\
\text { thinly mantied by } \\
\text { colluvium or morainal } \\
\text { deposits. }\end{array}$ & 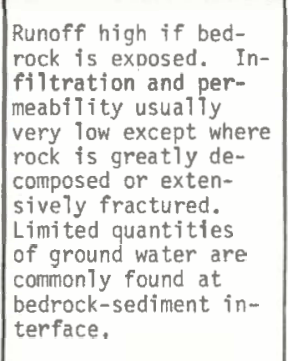 & $\begin{array}{l}\text { Fresh, unfractured } \\
\text { or non-weathered } \\
\text { bedrock does not } \\
\text { contain significant } \\
\text { quantitities of water } \\
\text { due to low porosity } \\
\text { and permeabiitity. }\end{array}$ & $\begin{array}{l}\text { Generatly poor. } \\
\text { Yields of } 1-5 \text { ga } 7 / \mathrm{min} \\
\text { obtained from spora- } \\
\text { dic fractures or } \\
\text { from the weathered } \\
\text { bedrock, if present. } \\
\text { Rare fracture zones } \\
\text { may yield } 70 \text { ga } 1 / \mathrm{m} 7 \mathrm{n} \\
\text { or more. }\end{array}$ & $\begin{array}{l}\text { Characteristics poor } \\
\text { for disposal of } 1 \text { iquid } \\
\text { wastes. Contaminants } \\
\text { may readify trave? for } \\
\text { great distances } \\
\text { through bedrock frac- } \\
\text { trures to reach wells } \\
\text { which may intersect } \\
\text { these fractures down- } \\
\text { gradient. }\end{array}$ \\
\hline
\end{tabular}




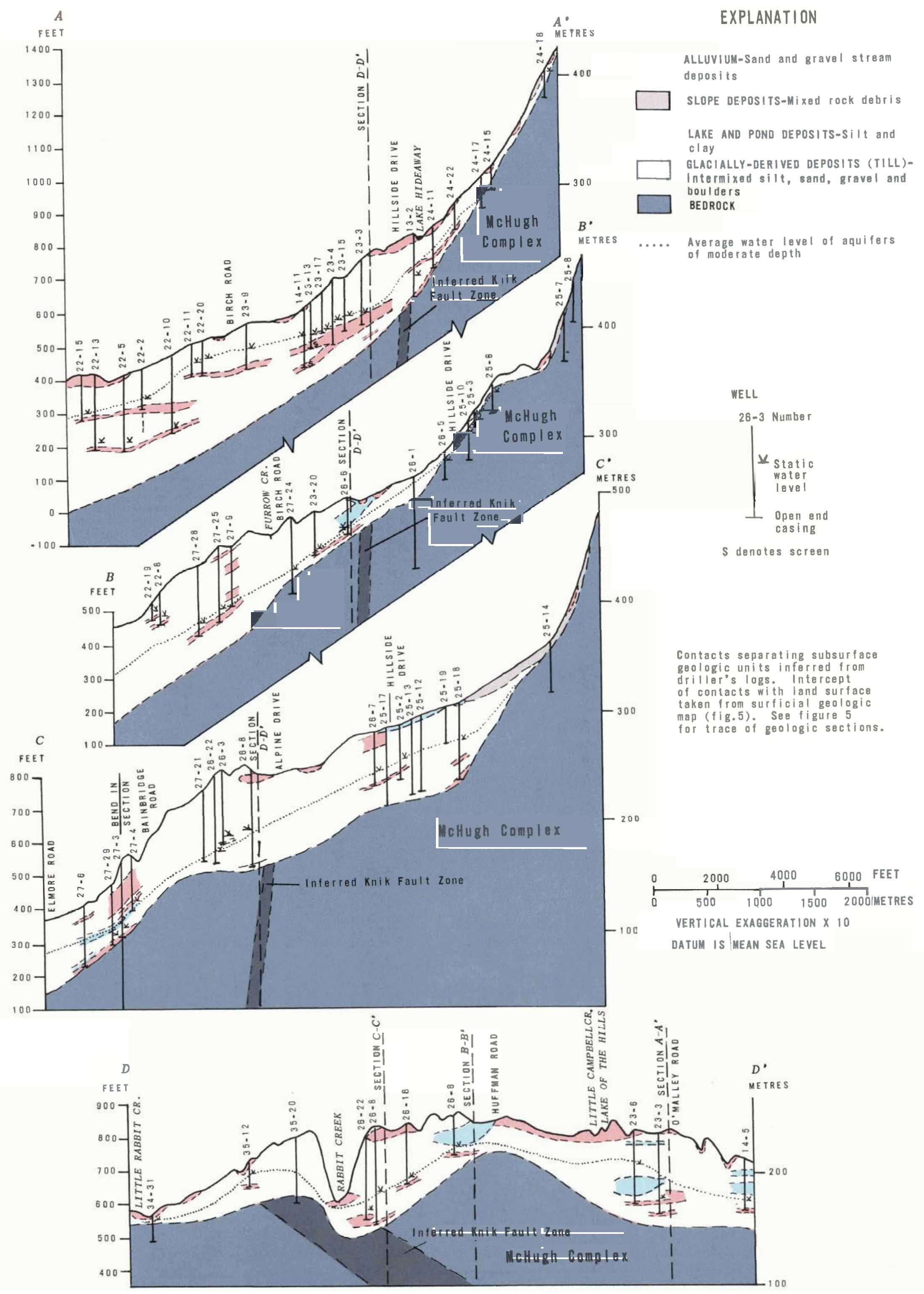

Figure 6.-- Generalized geologic sections. 
- THERE IS WIDESPREAD CONCERN THAT ADEQUATE WATER SUPPLIES MAY NOT BE AVAILABLE IN THE HILLSIDE AREA. FOR PURPOSES OF THIS REPORT, THE AREA HAS BEEN DIVIDED INTO TWO GROUND-WATER AVAILABILITY ZONES.

- THE UNCONSOLIDATED SAND AND GRAVEL AQUIFERS UNDERLYING THE AREA WEST OF HILLSIDE DRIVE PROBABLY CAN SUPPLY THE WATER NEEDS OF A RESIDENTIAL COMMUNITY OF 20,000 TO 40,000 PEOPLE, ASSUMING A PER CAPITA USE RATE OF 100 GALLONS (378 LITRES) PER DAY.

- IN CONTRAST, BEDROCK AQUIFERS WHICH UNDERLIE THE UPPER HILLSIDE AREA, GENERALLY EAST OF HILLSIDE DRIVE, ARE MUCH LESS PRODUCTIVE. TYPICAL YIELDS ARE LESS THAN 3 GAL/MIN (0.2 L/S), AND IN SOME LOCATIONS A RESIDENTIAL WATER SUPPLY MAY NOT BE AVAILABLE.

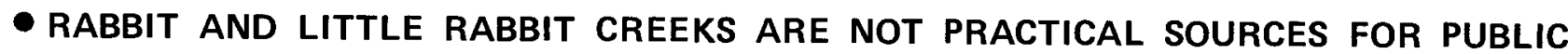
WATER SUPPLY BECAUSE OF THEIR LOW DISCHARGE IN WINTER MONTHS AND PROBABLE LACK OF SURFACE-STORAGE SITES.
}

Ground water in the Hillside area is obtained from many individual residential wells and from several public-supply wells. Wells generally produce water from either permeable unconsolidated sedimentary lenses of sand and gravel or fractured and weathered bedrock. The occurrence and abundance of ground water in the Hillside area is highly variable because favorable geologic conditions are irregularly distributed. Dry holes drilled 200-400 ft (61-122 m) into sediments or bedrock have been reported. In general, however, adequate water-yielding sediments are found at depths of less than $300 \mathrm{ft}(91 \mathrm{~m})$ in the area west of Hillside Drive and in places where the land-surface altitude is less than about $800 \mathrm{ft}(244 \mathrm{~m})$. At higher altitudes, wells commonly withdraw marginal supplies of water almost exclusively from bedrock at depths ranging from 50 to $400 \mathrm{ft}$ (15 to $122 \mathrm{~m}$ ).

\section{Unconsolidated Sediments}

The primary subsurface water-producing zones, termed aquifers, are lenses of sand and gravel within and between less permeable till layers. These aquifers are generally 1 to $5 \mathrm{ft}(0.3$ to $1.5 \mathrm{~m})$ thick and are rarely more than $10 \mathrm{ft}(3 \mathrm{~m})$ thick. Such deposits are often called stringers because they are thin and lack continuity as a result of deposition in small, braided, glacial stream channels. Their lateral extent is commonly only several hundred feet. As a result, correlation of individual aquifers from drillers' logs of wells (appendix A-1, A-2), even on adjacent lots, is often impossible. Aquifers are not abundant and make up only a small percentage of the total sediment thickness.

In most of the Hillside area, till does not yield appreciable water to wells due to its generally low permeability. However, a few wells are finished in loosely compacted, sandy or gravelly till and will produce $5 \mathrm{gal} / \mathrm{min}(0.3 \mathrm{l} / \mathrm{s})$ or more, an adequate supply of water for single-family use.
Compact and commonly "dry" layers within till that are very resistant to drilling are locally called hardpan. These strata are the chief confining layers in the artesian ground-water system underlying the Hillside area. Generally ground water more than 50 $\mathrm{ft}(15 \mathrm{~m})$ below the land surface is confined by hardpan. Consequently, water in most aquifers is under pressure and water levels in the wells tapping these aquifers will rise above the top of the water-bearing strata. However, in a few localities, ground water occurs above shallow "tight" till and water table (unconfined) conditions exist.

An indication of the thickness of glacial deposits and the distribution with depth of known aquifers are shown on four hydrogeologic sections (fig. 6) and on the sediment-thickness map (fig. 7). Sections $A-A^{\prime}, B-B^{\prime}$, and $C-C^{\prime}$ are perpendicular to the mountain front, whereas section D-D' parallels the mountain front at an approximate surface altitude of $700 \mathrm{ft}(213 \mathrm{~m})$. In many places, the lower limits of aquifers shown on the sections were not defined because most wells were drilled just deep enough to obtain a supply and do not fully penetrate the permeable zone. Water-bearing lenses that are very thin or produce silty water are not shown. Future drilling may discover significant aquifers between or below the aquifers shown.

In section A-A', parallel to O'Malley Road, unconsolidated sediments rapidly thicken to more than $200 \mathrm{ft}(61 \mathrm{~m})$ west of Lake Hideaway and to about $400 \mathrm{ft}(122 \mathrm{~m})$ in the western part of the map area. Seismic and drilling records indicate that at least $700 \mathrm{ft}(213 \mathrm{~m})$ of unconsolidated sediments overlie bedrock along the shore of Turnagain Arm, about $3 \mathrm{mi}(4.8 \mathrm{~km})$ farther west. The thickness of unconsolidated sediments along section B-B', approximately parallel to Huffman Road, follows the same general trend as section $\mathrm{A}^{-\mathrm{A}^{\prime}}$ and increases rapidly near Birch Road. 


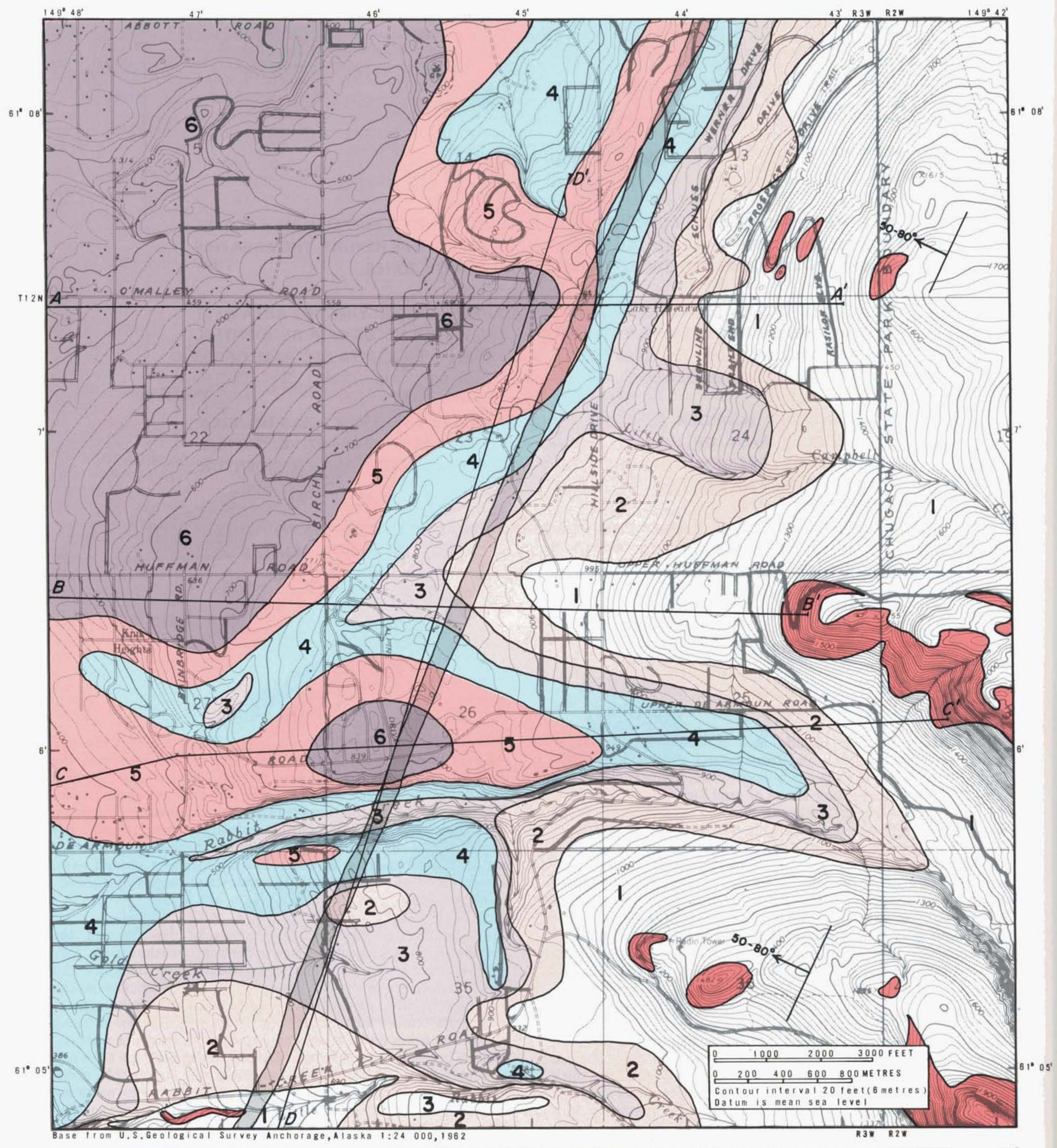

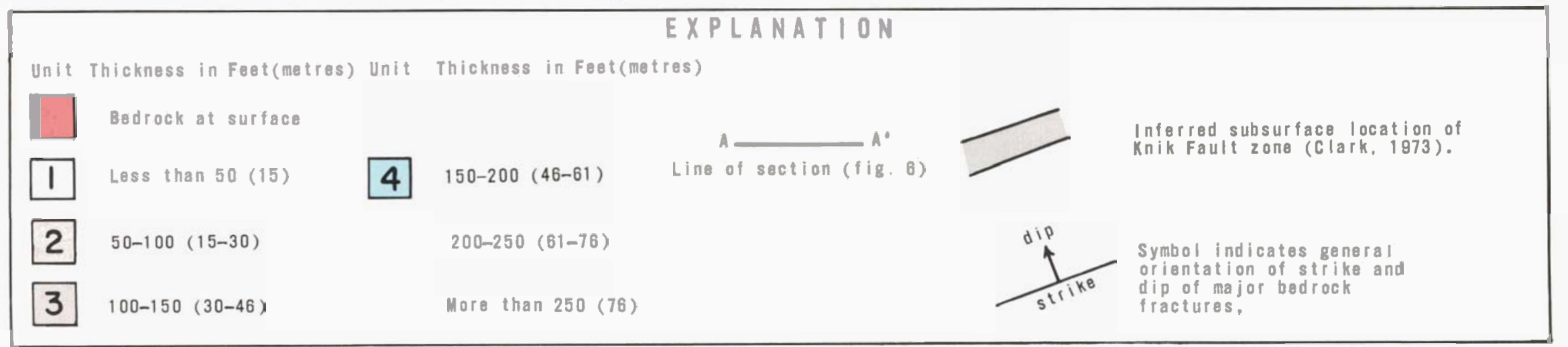

Figure 7.-- Thickness of unconsolidated sediments overlying bedrock. 
However, the thickness of saturated sediments is about $100 \mathrm{ft}(30$ $\mathrm{m}$ ) less along this section than in the O'Malley Road section. Sections C-C' and D-D' indicate that a buried bedrock ridge extends westward from the Chugach Mountain front to the vicinity of Bainbridge Road (figs. 6 and 7). Sediments overlying the ridge are thin. These two sections also indicate a thinning of water-saturated sediments in the Rabbit and Little Rabbit Creek basins in the southern Hillside area. Here, several perched water zones have been found above the main ground-water body, but their yields were inadequate for well development.

The probable range of drilling depth required to reach aquifers in the map area can be estimated from figure 8. This map shows depths to the shallowest water-yielding stratum that generally will produce an adequate water supply for domestic use (approximately $5 \mathrm{gal} / \mathrm{min}$, or $0.3 \mathrm{l} / \mathrm{s}$ ).

Aquifers commonly are more than $200 \mathrm{ft}(61 \mathrm{~m})$ below land surface along the north side of Rabbit Creek. These aquifers probably were deposited in the pre-Wisconsin stream channel of Rabbit Creek and are oriented in an east-west direction. Water levels in wells tapping these strata are relatively deep, and pumping lifts are nearly $200 \mathrm{ft}(61 \mathrm{~m})$.

Water levels in wells finished in confined aquifers indicate a gradual loss of hydraulic head toward Turnagain Arm (see fig. 6 sec. A-A', B-B', and C-C'). Most strata are hydraulically connected and any well pumped at a high rate will cause water-level decline in nearby wells. In several areas where shallow unconfined ground water is perched above the deeper confined water, the hydraulic connection between water table and deeper aquifers probably is severely restricted.

Figure 9 is a generalized map of the depth below land surface to which water rises in wells tapping aquifers generally lying 100-250 ft $(31-76 \mathrm{~m})$ deep. The height of the water column in a proposed well can be estimated by subtracting the most probable depth to the water level (interpolated at the well site using figure 9) from the anticipated depth to the aquifer (fig. 8). The minimum height of pump lift at a well site can also be determined directly from figure 9.

Pumping data from well-construction records are shown in appendix A-3. The data consists of the pumping rate, water-leve drawdown, and duration of pumping during well development at various sites. Generally, yields from open-end, 6-in $(25 \mathrm{~mm})$ diameter wells are less than $10 \mathrm{gal} / \mathrm{min}(0.6 \mathrm{l} / \mathrm{s})$ in the Hillside area. However, yields of nearly $300 \mathrm{gal} / \mathrm{min}(19 \mathrm{l} / \mathrm{s})$ have been obtained from a few large-diameter wells that are finished with screens. Some domestic-supply wells that are $300 \mathrm{ft}(91 \mathrm{~m})$ or more deep produce as little as $1 \mathrm{gal} / \mathrm{min}(0.06 \mathrm{l} / \mathrm{s})$.

The probable maximum yield of wells listed in appendix A-1, or other Hillside wells similarly constructed, may be estimated by multiplying the ratio of the recorded yield for a given well to the corresponding drawdown by the total permissible drawdown in that well. For example, if a well was pumped at $10 \mathrm{gal} / \mathrm{min}(0.6$ $\mathrm{l} / \mathrm{s})$ and drawdown at that pumping rate stabilized at $20 \mathrm{ft}(6 \mathrm{~m})$ below the non-pumping water level and if the maximum allowable drawdown is $80 \mathrm{ft}(24 \mathrm{~m})$, then it is probable that $40 \mathrm{gal} / \mathrm{min}(2.5$ $\mathrm{l} / \mathrm{s}$ ) can be pumped for at least short periods of time.

\section{Bedrock}

Two bedrock units having very low permeability underlie the unconsolidated sediments of the Hillside area (Clark, 1973). An inferred northeastward-trending fault, named the Knik fault separates the McHugh Complex that consists of metamorphosed coarse clastic and submarine volcanic rocks of Jurassic and (or)
Cretaceous age on the east from older, more highly metamorphosed rocks of Permian to Jurassic age on the west.

The yield of bedrock wells is commonly low and often insufficient for a residential supply. Ground water generally is obtained from weathered or fractured zones where they are present in the metamorphosed bedrock. However, many water-bearing fractures do not supply enough water, and some wells have to tap multiple fractures at various depths. Table 2 indicates that about 70 percent of bedrock wells checked in the Hillside area east of Hillside Drive produce less than $5 \mathrm{gal} / \mathrm{min}(0.3 \mathrm{l} / \mathrm{s})$. About 40 percent of the wells produce less than $3 \mathrm{gal} / \mathrm{min}(0.2 \mathrm{l} / \mathrm{s})$.

\begin{tabular}{|l|c|c|}
\hline \multicolumn{2}{|l|}{ Table 2.- Yields from bedrock wells. } \\
\hline Yield, in gpm & Number of wells & Percent of total \\
\hline 1 or less & 11 & 28 \\
Between 1 and 5 & 16 & 41 \\
5 or more & 12 & 31 \\
Total & 39 & 100 \\
\hline
\end{tabular}

Knowledge of the location and the general orientation of fractures in bedrock can help in the selection of well sites in the eastern Hillside area. In this area the trend of fractures is northeast-southwest (Clark, 1973). The dip, or inclination, of the fracture planes is mostly 50 to 70 degrees from the horizontal plane and inclined to the northwest. Consequently, the probability of success for a new well will be highest if it is located either to the northeast or southwest of a nearby bedrock well successfully completed in fractured bedrock.

A zone of weathered bedrock is generally present at the contact between bedrock and overlying sediments, except in the easternmost (high altitude) area. It commonly is thinner than $5 \mathrm{ft}$ $(1.5 \mathrm{~m})$ but may be as thick as $25 \mathrm{ft}(7.6 \mathrm{~m})$. Wells generally produce more than $3 \mathrm{gal} / \mathrm{min}(0.2 \mathrm{l} / \mathrm{s})$ from weathered bedrock that is more than $5 \mathrm{ft}(1.5 \mathrm{~m})$ thick, but they produce less from thinner zones. The extent, thickness, and hydrologic characteristics of the weathered zone are poorly defined at present because most wells have been completed in the overlying sediments.

In many places where the weathered bedrock zone does not yield sufficient water, wells are drilled deeper. Most of these wells intersect fractures at depths of less than $250 \mathrm{ft}(76 \mathrm{~m})$ below the bedrock surface. 'These fractures generally yield 1 to $5 \mathrm{gal} / \mathrm{min}$ $(0.06$ to $0.3 \mathrm{l} / \mathrm{s})$, and the yield decreases with depth. However, one well (well 21 , sec. 25) was drilled nearly $400 \mathrm{ft}(122 \mathrm{~m}$ ) into bedrock before adequate water from fractures was obtained.

In summary, because bedrock yields are low, every effort should be made to locate and complete wells at sites where the unconsolidated sediments are thickest. The probability of finding aquifers increases as the thickness of sediment overlying bedrock increases. Figure 7 shows the generalized thickness of the unconsolidated sediments overlying bedrock. Bedrock is at or near the surface and the sedimentary layer is thin in much of the eastern half of the study area (map units 1-3). In the northwest quarter of the study area (unit 7), the depth to bedrock increases to more than $250 \mathrm{ft}(76 \mathrm{~m})$. 


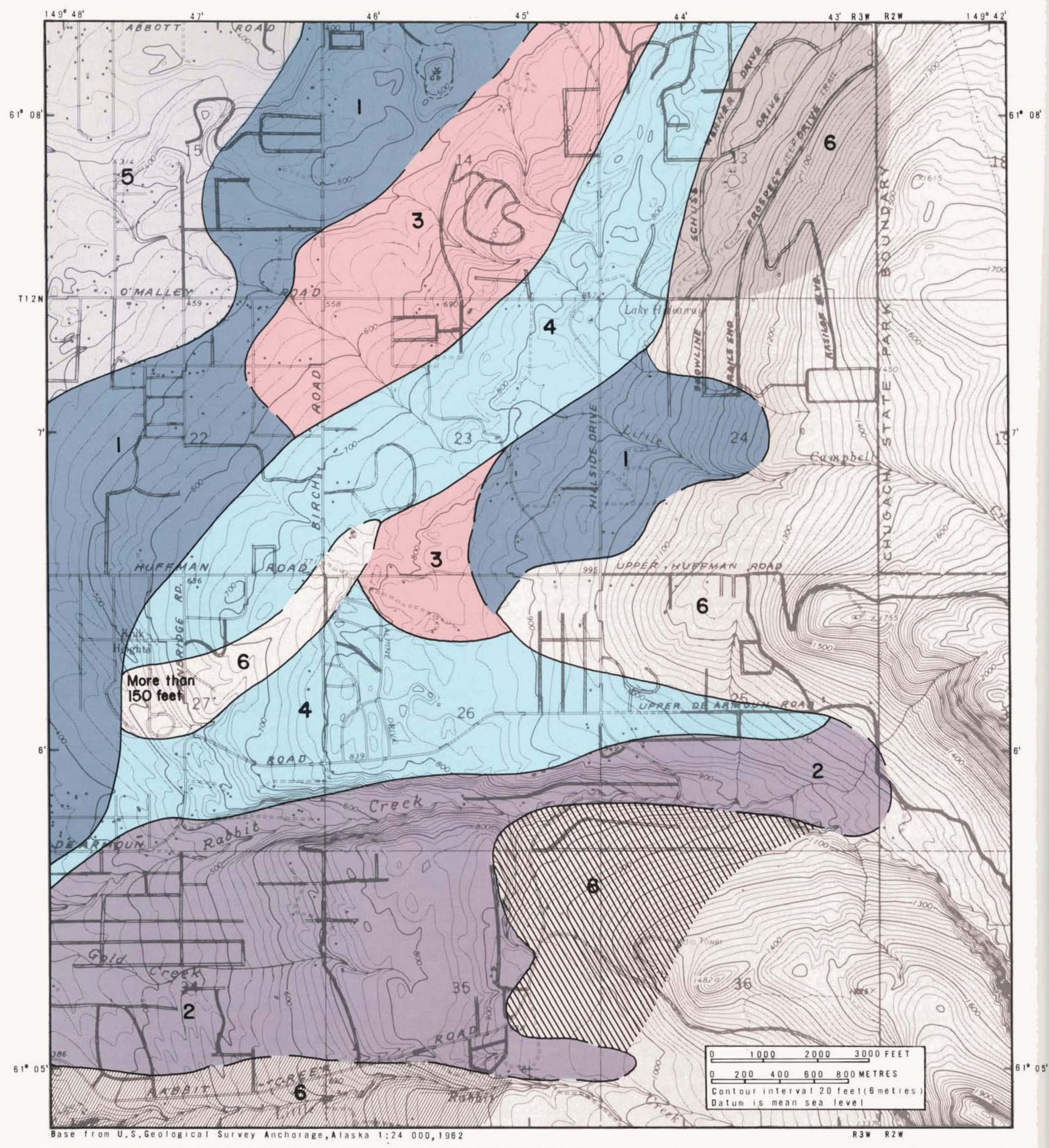

\begin{tabular}{|c|c|c|}
\hline & PREDOMINANTLY UNCONSOLIDATED AQUIFERS & EXPLANATIDN \\
\hline Unit. & $\begin{array}{l}\text { Depth below land surface in foet(metros) } \\
\text { Less than } 100(30)\end{array}$ & $\begin{array}{l}\text { Unit Depth below land in leat(metres) } \\
\text { 50-400(15-122) highly variable }\end{array}$ \\
\hline 2 & $50-150(15-46)$ & Generally $50-150(15-46)$ \\
\hline 3 & $100-150(30-46)$ & More than $100(30)$ \\
\hline 4 & $150-250(46-76)$ & Generatly $100-200(30-61)$ \\
\hline 5 & $150-300(46-91)$ & $\begin{array}{l}\text { All contacts between adjacent units are gradational. } \\
\text { Contacts are dashed where poorly defined. }\end{array}$ \\
\hline
\end{tabular}




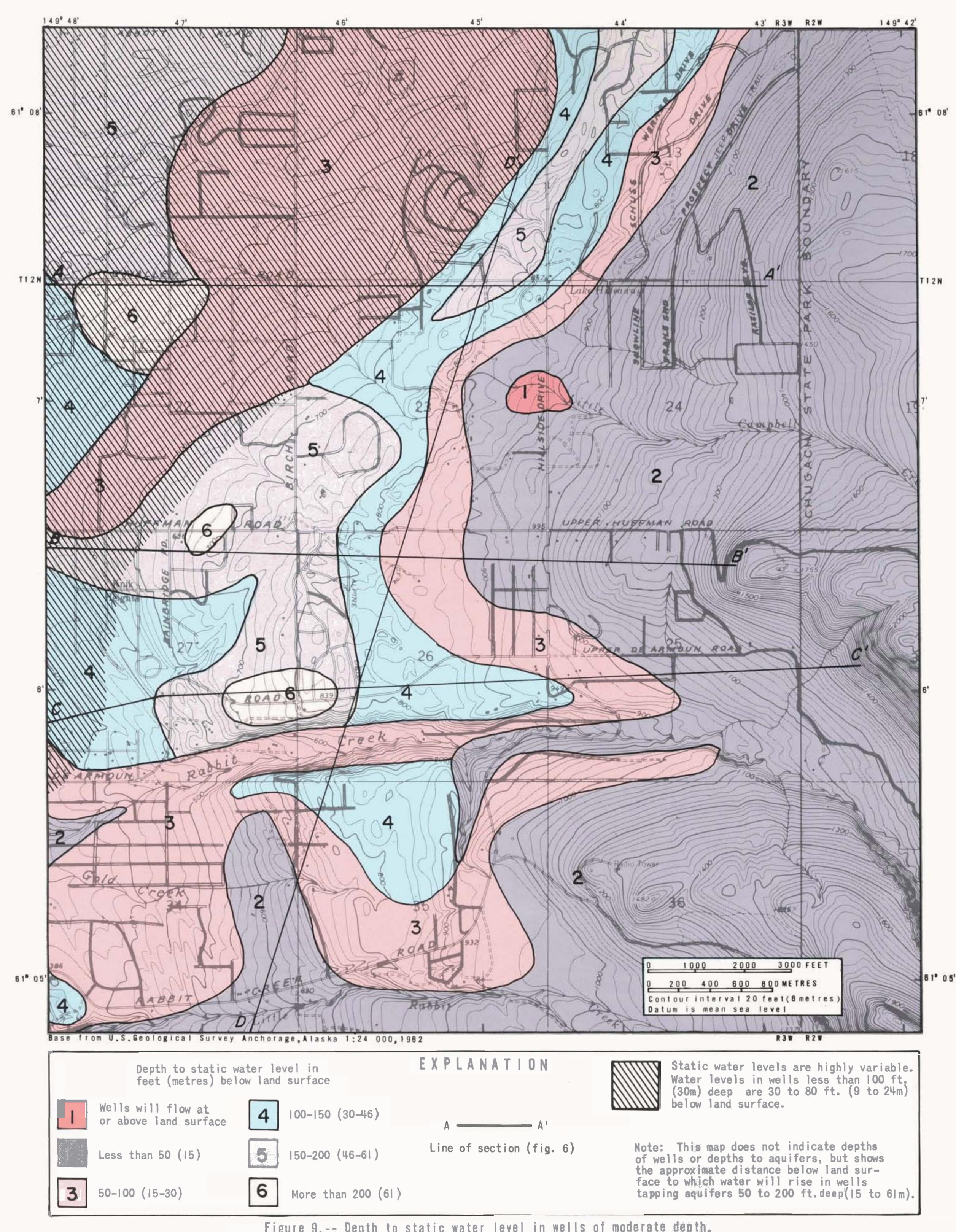




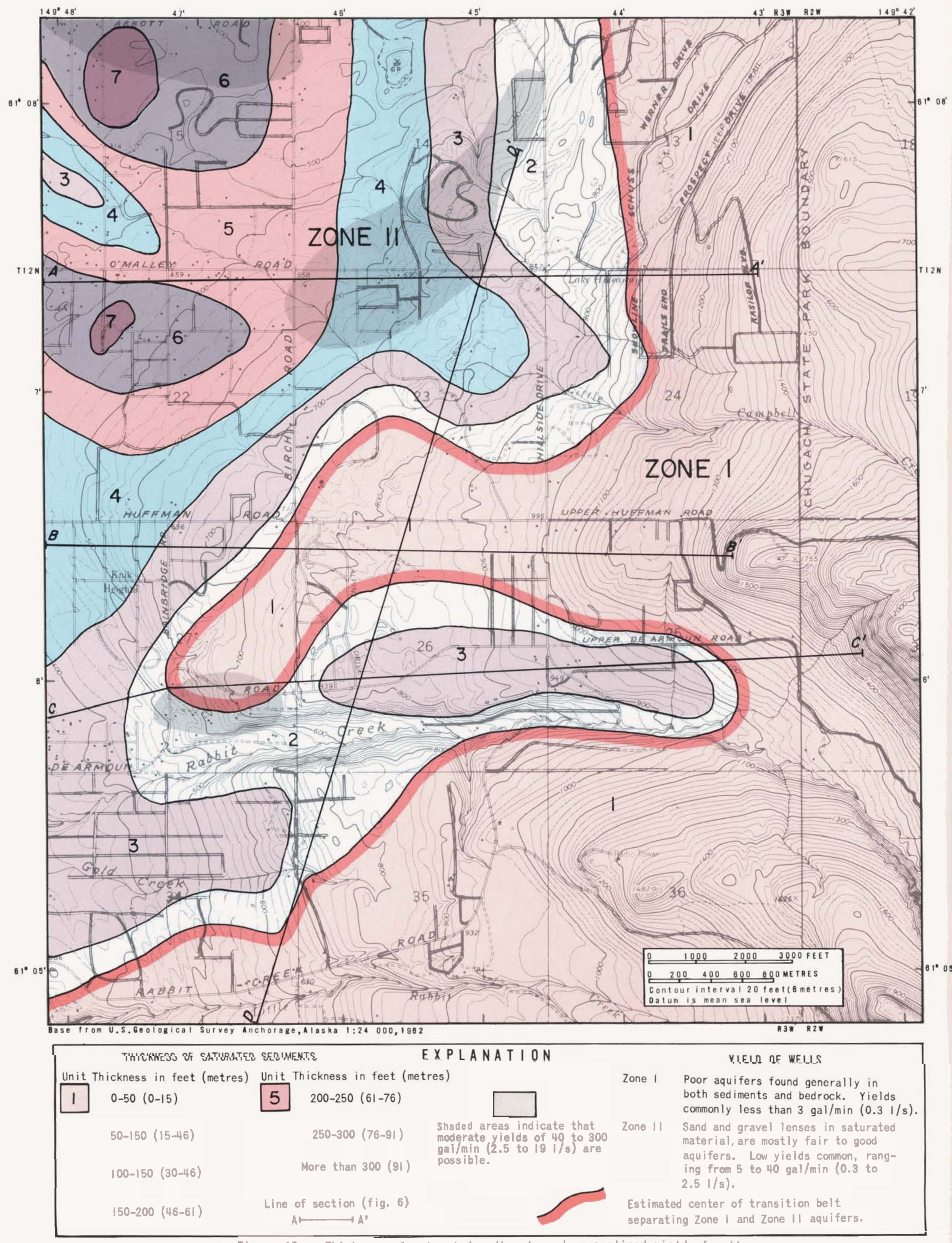

Figure 10.-- Thickness of saturated sediments and generalized yield of wells. 


\section{Outlook for Ground Water}

For planning purposes, zones of ground-water availability are delineated in figure 10 . In zone I saturated sediments overlying bedrock are less than $50 \mathrm{ft}(15 \mathrm{~m})$ thick, aquifers are scarce, and well yields rarely exceed $10 \mathrm{gal} / \mathrm{min}(0.5 \mathrm{l} / \mathrm{s})$. Most wells draw water from the underlying bedrock where yields generally are less than $5 \mathrm{gal} / \mathrm{min}(0.3 \mathrm{l} / \mathrm{s})$. The present average daily pumpage from zone $I$ is estimated at $0.1 \mathrm{Mgal} / \mathrm{d}\left(0.004 \mathrm{~m}^{3} / \mathrm{s}\right)$.

In zone II where more than $50 \mathrm{ft}(15 \mathrm{~m})$ of saturated sediments overlies bedrock most wells tap unconsolidated sedimentary aquifers. Although shown as a line in figure 10, the boundary separating zone I from zone II is gradational. Aquifers in zone II generally yield 5 to $40 \mathrm{gal} / \mathrm{min}(0.3$ to $2.5 \mathrm{l} / \mathrm{s})$ to domestic wells finished with open-end casings. In the three dotted areas shown in figure 10, well-yield data indicate a high probability that yields of 70 to $300 \mathrm{gal} / \mathrm{min}(4.4$ to $19 \mathrm{l} / \mathrm{s})$ may be obtained. Present production from unconsolidated sedimentary aquifers in zone II is estimated at $0.3 \mathrm{Mgal} / \mathrm{d}\left(0.01 \mathrm{~m}^{3} / \mathrm{s}\right)$.

Total ground-water pumpage in the study area is about $0.4 \mathrm{Mgal} / \mathrm{d}$ $\left(0.014 \mathrm{~m}^{3} / \mathrm{s}\right)$ from both zones. Pumpage was estimated by assuming that the 4,000 residents in the area use 100 gallons $(378 \mathrm{l})$ of water per day per person

\section{The Natural Water Budget}

An approximation of the water budget in four Hillside basins (fig. 11) can be used to obtain perspective on long-term availability of ground water. Assuming that a nearly constant volume of water enters the area annually through precipitation, streamflow, and ground-water inflow (fig. 12) and that ground-water storage remains constant year after year, the same quantity of water must leave the area on an annual basis as enters it. Under this long-term, steady condition ground-water recharge equals ground-water discharge, and the flow of water through the subsurface sediments maintains relatively constant ground-water levels. An equation representing the natural water budget in the area shown as underlain by sedimentary aquifers in figure 11 is:

Precipitation + stream inflow + ground-water inflow $=$ stream outflow + evaporation + transpiration + ground-water outflow \pm change in storage.

The average daily flow of ground water (fig. 11) is estimated to be 10 to $16 \mathrm{Mgal} / \mathrm{d}\left(0.4\right.$ to $\left.0.7 \mathrm{~m}^{3} / \mathrm{s}\right)$. Although the subsurface materials transmit at least $10 \mathrm{Mgal} / \mathrm{d}\left(0.4 \mathrm{~m}^{3} / \mathrm{s}\right)$ and contain a vast amount of water in storage, only a small percentage is recoverable through wells. Permeable deposits, or aquifers, occupy a very small part of the total volume of saturated materials and, therefore, wells can withdraw water only in a severely limited spatial arrangement. Water flows at exceedingly low rates from till deposits to aquifers because most tills have very low permeabilities. Consequently, recharge to some aquifers may be insufficient to maintain withdrawal rates from domestic wells for prolonged periods.

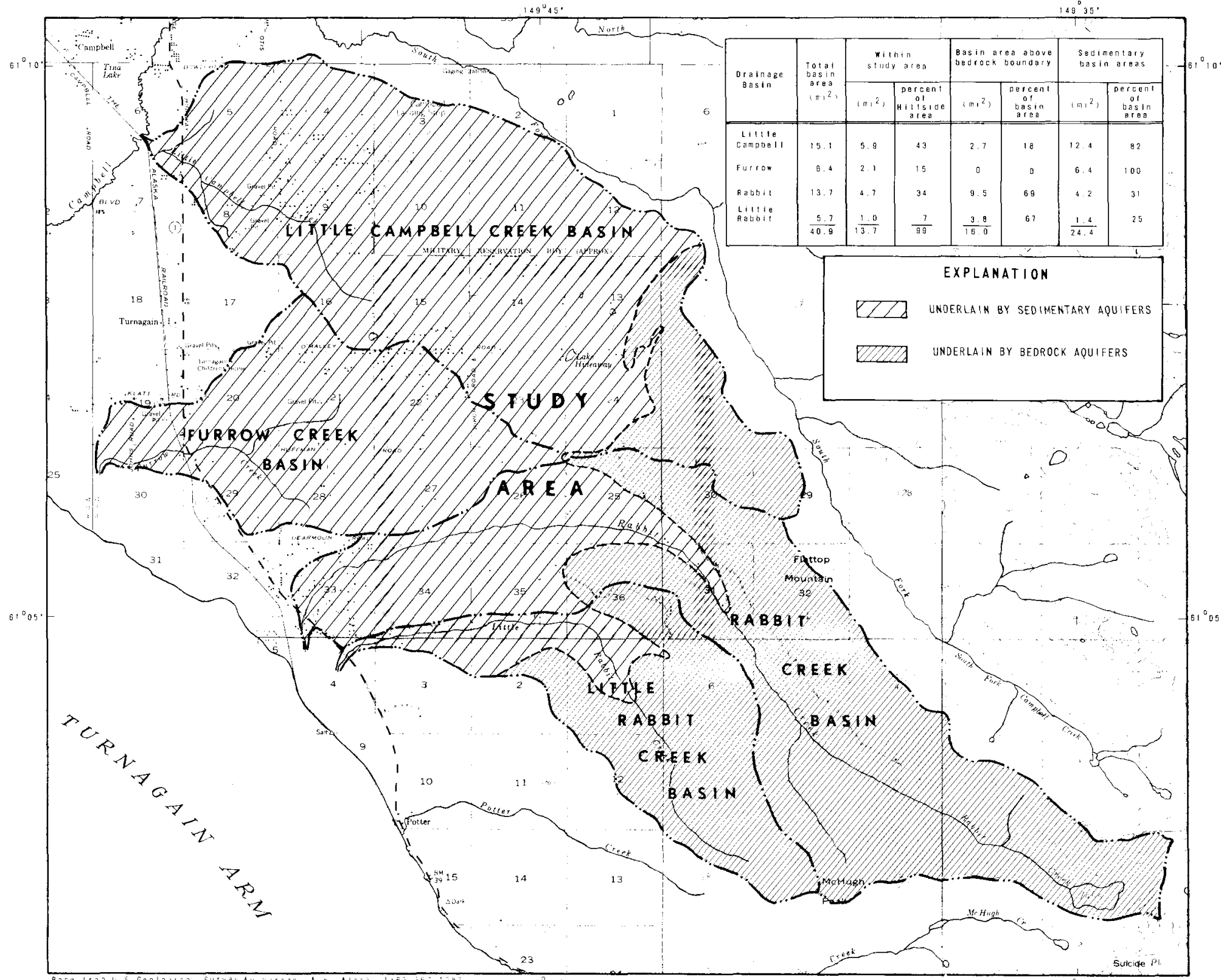

Figure 11.-- Drainage basins in the Hillside area. 


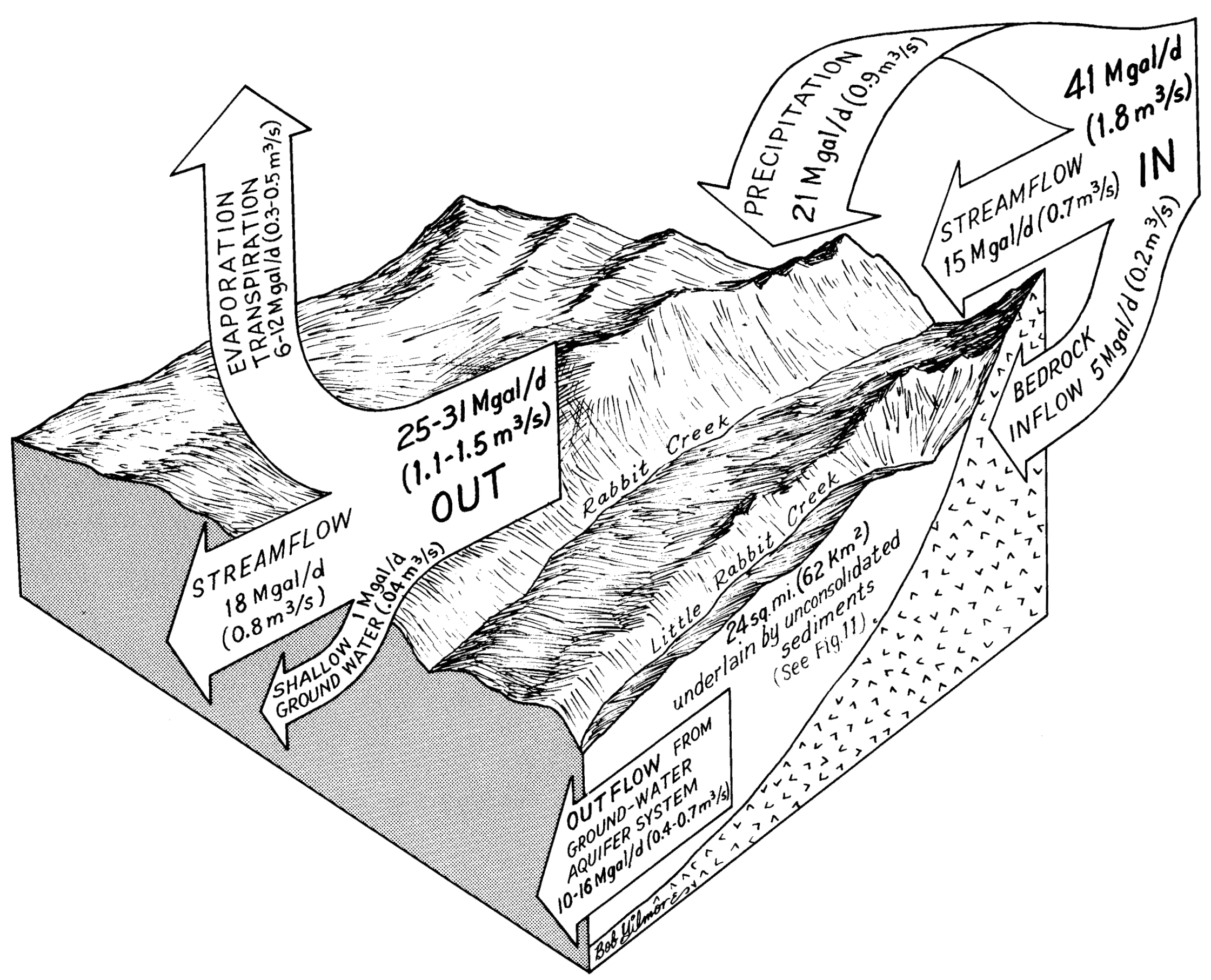

Figure 12.-- Water budget of the area underlain by sedimentary aquifers.

\section{Estimation of Ground-Water Yield}

Assuming the rate of recharge remains constant, as shown in figure 12 , an estimated sustained yield of 2 to $4 \mathrm{Mgal} / \mathrm{d}(0.08$ to 0.17 $\mathrm{m}^{3} / \mathrm{s}$ ) can be developed in zone II (fig. 10), enough to supply 20,000 to 40,000 residents. Pumpage at these rates may best be achieved through numerous, evenly distributed, low-yield wells so that water levels will not be excessively drawn down in any locality. Present data suggest that sustained yields of more than $0.1 \mathrm{Mgal} / \mathrm{d}$ ( $70 \mathrm{gal} / \mathrm{min}$ or $4.4 \mathrm{l} / \mathrm{s}$ ) may be possible in three areas shown in figure 10 , or in about 10 percent of the total study area. Interference with existing individual residential wells can be minimized if sufficient spacing is used when locating public-supply wells.

At this time, the potential areal yield from zone I cannot be determined. However, the probability of successfully completing a public-supply well is poor. In much of this area the clustering of domestic wells within small tract developments may not be desirable because the total quantity of recoverable water in bedrock fractures can be so small that closely-spaced wells may deplete the local supply.

In areas where yields of bedrock wells are less than about 2 $\mathrm{gal} / \mathrm{min}(0.1 \mathrm{l} / \mathrm{s})$ some wells have been drilled 100 to $200 \mathrm{ft}$ (30 to $61 \mathrm{~m}$ ) deeper than the producing zone, resulting in additional water storage within the well bore. This water is recovered by setting the pump intake near the bottom of the well. As an alternative, surface tanks with water-holding capacities of several hundred gallons can be used to compensate for marginal well yields. 


\section{Streams}

The study area includes three major drainage basins, Little Campbell, Rabbit and Little Rabbit Creeks, and the headwaters of a fourth basin, Furrow Creek (fig. 11). Stream discharge from the major basins is small, but all streams flow year-round. A stream channel has not developed in upper Furrow Creek basin and recent runoff is not evident.

The drainage in Little Campbell Creek basin is poorly developed west of Hillside Drive. A main channel heads in mountainou terrain at about $1,300 \mathrm{ft}(396 \mathrm{~m})$ altitude. At lower altitudes Little Campbell Creek flows in a narrow meandering channel through several swampy areas that lie between stream reaches with steeper gradients and straighter channels. Small intermittent tributaries flow from springs or drain wet land and join the main channel below Hillside Drive. Although no residents are known to use creek water for household use, some water is reportedly diverted for livestock. Streamflow less than $1 \mathrm{Mgal} / \mathrm{d}\left(0.04 \mathrm{~m}^{3} / \mathrm{s}\right)$ during most of the year and often severe winter icing almost completely stops flow. The creek derives much of its flow from ground-water seepage.

Rabbit and Little Rabbit Creeks in the southern Hillside area exhibit flow characteristics similar to Campbell and Ship Creeks near Anchorage. They head at higher altitudes in the bedrock terrain of the Chugach Mountains and, like Ship Creek (Barnwell and others, 1972), have no significant tributaries downstream from the mountain front. Rabbit Creek flows from a 150-acre (0.6$\mathrm{km}^{2}$ ) lake that occupies a remnant glacial cirque about $5 \mathrm{mi}(8$ $\mathrm{km}$ ) southeast of the report area (fig. 11)

The mean annual flow of Rabbit Creek near its mouth is estimated from water-budget studies and miscellaneous discharge measurements to be about $11 \mathrm{Mgal} / \mathrm{d}\left(0.5 \mathrm{~m}^{3} / \mathrm{s}\right)$. Two sets of streamflow measurements made in April 1972 and 1973 during low flow indicate no appreciable loss or gain of water below an altitude of $900 \mathrm{ft}(272 \mathrm{~m})$. This suggests that ground-water seepage is not a significant increment of streamflow under low flow conditions. A flow of $3 \mathrm{Mgal} / \mathrm{d}\left(0.1 \mathrm{~m}^{3} / \mathrm{s}\right)$ was measured in April 1972 at the Old Seward Highway before spring runoff. Simultaneous measurements made at three points along Rabbit Creek in September 1971 indicate a gain of about $1 \mathrm{Mgal} / \mathrm{d}$ from Hillside Drive to the Old Seward Highway.

Water-budget studies and miscellaneous measurements indicate that the mean annual flow of Little Rabbit Creek near its mouth is approximately $4 \mathrm{Mgal} / \mathrm{d}\left(0.2 \mathrm{~m}^{3} / \mathrm{s}\right)$. Field measurements made at low flow during April 1972 and 1973 and at medium flow in September 1971 indicate a small downstream gain. A low flow of $0.75 \mathrm{Mgal} / \mathrm{d}\left(0.03 \mathrm{~m}^{3} / \mathrm{s}\right)$ was measured in early April 1972 at the Old Seward Highway.

Water from both Rabbit and Little Rabbit Creeks has been used for household purposes by residents living near these streams. In recent years, however, drilled wells have become the predominant water source because ground water is a more convenient supply and is not as susceptible to contamination.

Based on discharge data, Rabbit Creek may have some potential as a water-supply source. Because of the low winter flow of Rabbit Creek, storage in a sizable surface reservoir would be required in order to provide a significant firm yield. Although dam sites have not been studied, the lake at the head of Rabbit Creek may be suitable as a storage reservoir.

\section{$\underline{\text { Springs }}$}

Small localized springs are common in the Hillside area (fig. 13). Most of these springs flow at less than $1 \mathrm{gal} / \mathrm{min}(0.06 \mathrm{l} / \mathrm{s})$ and do not have sufficient flow to be considered sources of domestic water. In a few places, abnormally large springs have been developed for single-family use by digging shallow sumps which serve as storage reservoirs. The flow of some of these developed springs is reported to have declined or stopped during prolonged cold periods. In general, springs are undependable water sources in the area, and many may become contaminated from animal or human wastes.

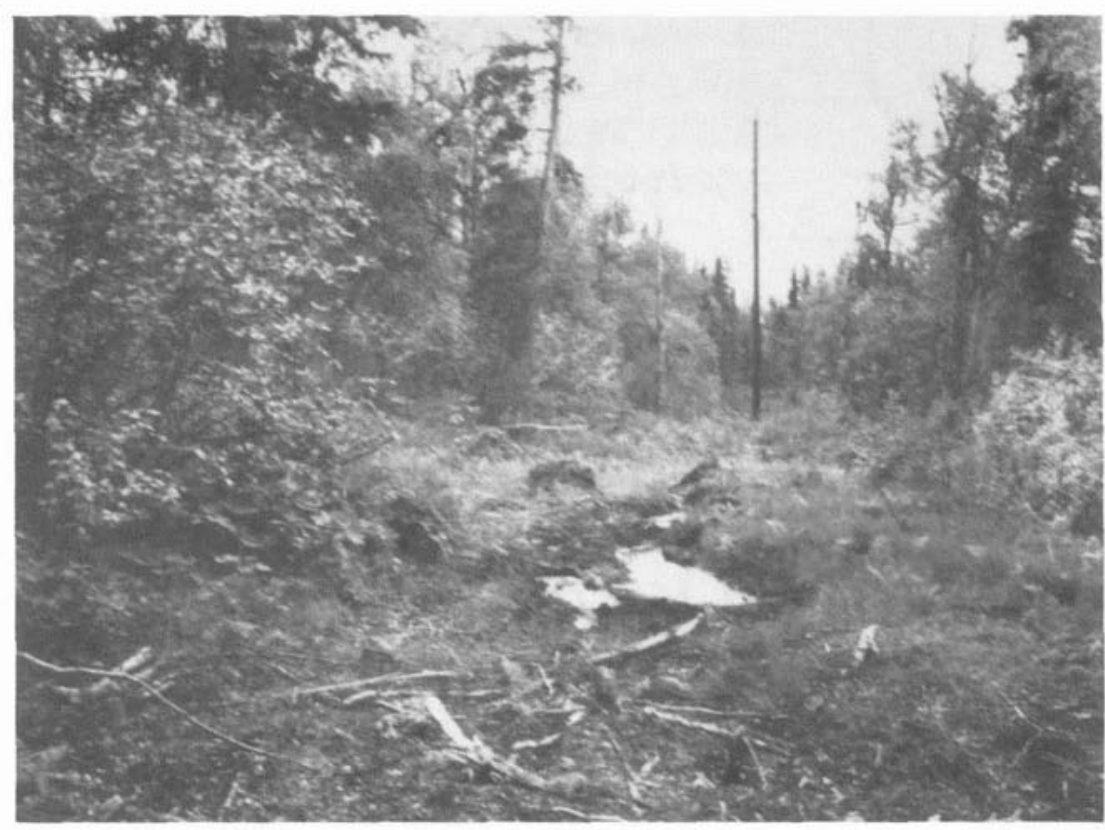

Figure 13.-- Water from springs along a power line.

Ground water surfaces upslope (left side) and seeps into a deep bulldozer rut. Although a shallow sump may be capable of supplying enough water for a household, the source may freeze or become contaminated. 


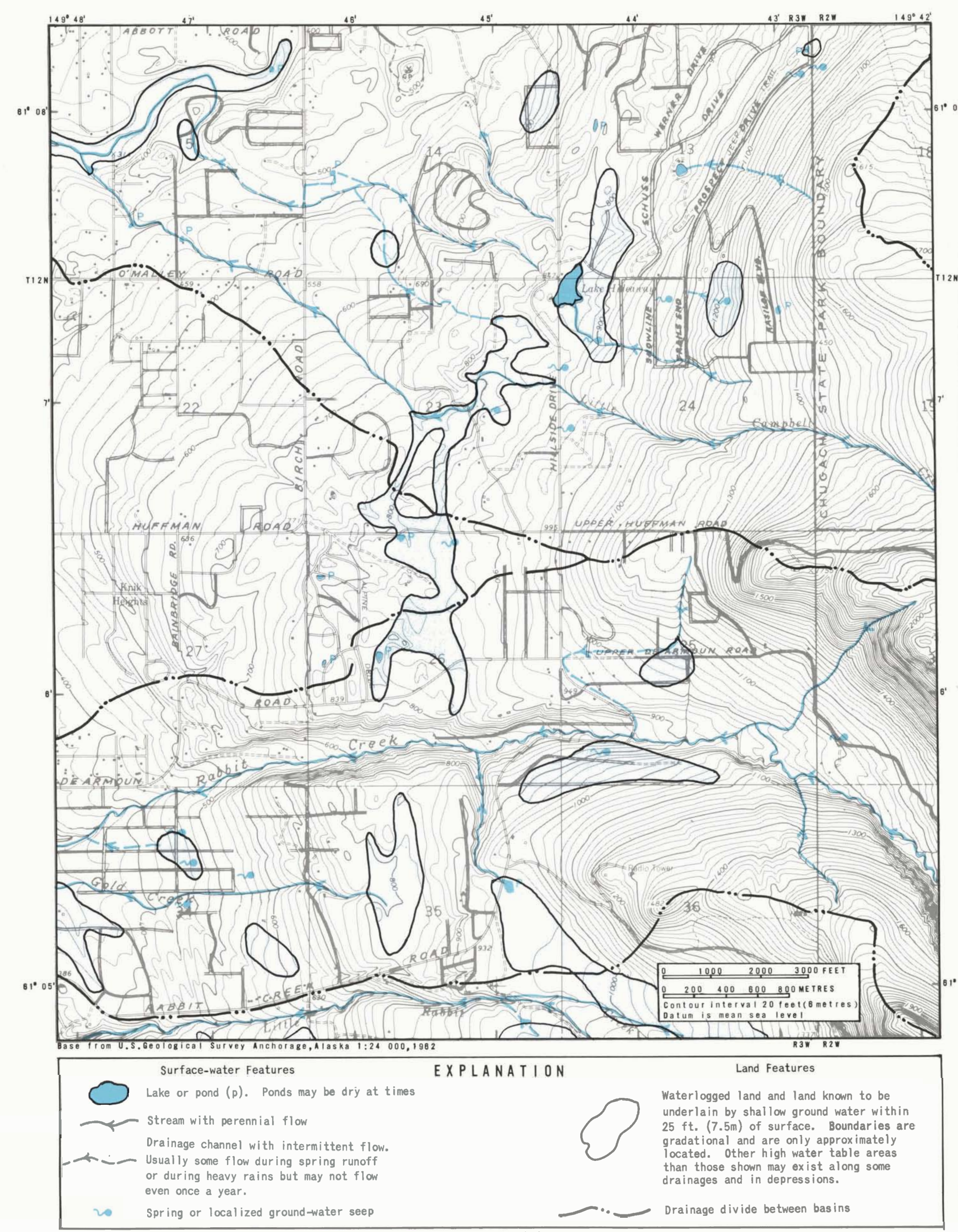

Figure 14.-- Land drainage. 


\section{- LOCALIZED RUNOFF PROBLEMS OCCUR ANNUALLY DURING SPRING THAW. AND IN OTHER LOCALITIES DRAINAGE PROBLEMS MAY DEVELOP DURING HEAVY OR EXTENDED RAINSTORMS.}

- MOST OF THE HILLSIDE AREA IS WELL ABOVE THE ALTITUDE OF THE MAJOR FLOOD
PLAINS, BUT SMALLER DRAINAGE CHANNELS AND ROADSIDE DITCHES MAY NOT ACCOMMODATE HEAVY RUNOFF AND COULD OVERFLOW ROADWAYS AND YARDS.

\footnotetext{
- CONSTRUCTION OF ROADS AND HOMES ON POORLY DRAINED LAND IS CAUSING DRAINAGE PROBLEMS. WHERE SWAMPS AND LESS OBVIOUS WATERLOGGED CONDITIONS EXIST, SEEPAGE PROBLEMS AND STRUCTURAL DAMAGE CAUSED BY FROST HEAVING COMMONLY PLAGUE DEVELOPMENT. ROADS CONSTRUCTED ACROSS THESE AREAS OFTEN BECOME IMPASSABLE DURING THE SPRING THAW AND MAY BE COVERED BY SIZEABLE ICINGS DURING THE WINTER.
}

Provision for drainage and storm runoff is becoming increasingly necessary as residential development and other construction projects proceed. In the past, homesteaders avoided localities with a high potential for drainage problems by building homes and roads on the ridges and knobs. Now, with the increasing demand for new homesites, development is beginning to infringe on waterlogged land, areas of ground-water seepage or flowing springs, and flood plains.

In this section of the report, two major drainage considerations, waterlogged lands and channeling of surface runoff, are discussed in relation to potential water problems faced by planners and large-tract developers. These potential problems are the result of pronounced variations in topography and surficial geology. Consequently, detailed hydrological studies may be needed to adequately define the extent and magnitude of surficial drainage characteristics at specific sites.

\section{Waterlogged Areas}

The principal waterlogged areas of the Hillside area are shown in figure 14. In these places the ground is generally saturated at or close to the surface. Other areas of waterlogged surficial material not defined on this map undoubtedly occur. Frequently, it is possible to predetermine the location of these areas and the probable potential for drainage problems by noting the type of surficial material (see fig. 5 and table 1) and the slope of the land. Generally, shallow subsurface drainage will be good where permeable deposits occur on sloping land. Conversely, poor drainage can be expected in fine-grained deposits and on gently sloping land where a thin layer of permeable material is immediately underlain by tight material.

Some low-lying areas contain ponded surface water during years of normal precipitation but become dry during drought periods. Field inspection, preferably during spring runoff, is invaluable in evaluating potential surficial drainage problems. Test borings to a depth of at least $15 \mathrm{ft}(4.5 \mathrm{~m})$ or to the water table may be needed to adequately delineate the depth to ground water.
Perched ground water occurs in some muskeg-filled depressions and may have no connection with the deeper lying water table. Peaty material on the surface often appears dry, but it acts as a sponge and normally is saturated 1 or $2 \mathrm{ft}(0.3$ or $0.6 \mathrm{~m})$ beneath the surface. Material below the peat, however, may not be saturated. If wet muskeg is removed and adequate surface drainage provided, these lands may be made suitable for development.

Continuously flowing springs and areas of ground-water seepage occur throughout the area (fig. 14), particularly where moderate to steep landslopes flatten abruptly. Also seepages commonly develop along the uphill banks of roads cut into major slopes. Although not mapped, intermittent seeps are likely to form during wet periods where permeable surficial material (such as alluvium, see fig. 5) lies in contact with and upslope from clay deposits or impermeable fine-grained till. The flow of ground water from these drainage features generally is very low; however, roads built immediately downslope usually require frequent maintenance (fig. $15)$.

During winter months, the discharge from springs often freezes and forms sizeable icings. Roads that are constructed in seepage areas may become hazardous to traffic during the winter (fig. 16) Although the source of icings cannot be eliminated, the effect of icings can often be substantially reduced by consideration of local conditions in road design.

Surface Runoff

Mean annual streamflow through the Hillside area approximates $18 \mathrm{Mgal} / \mathrm{d}\left(0.8 \mathrm{~m}^{3} / \mathrm{s}\right)$. However, about $15 \mathrm{Mgal} / \mathrm{d}\left(0.7 \mathrm{~m}^{3} / \mathrm{s}\right)$ of this flow originates in the mountains east of the study area (fig. 12). Two major streams, Rabbit and Little Rabbit Creeks, conduct most of the mountain runoff through the area and into Turnagain Arm. These streams flow in straight valleys that slope steeply westward (fig. 14); their channels meander through narrow flood plains in the valley bottoms. Little Campbell Creek flows on glacial sediments in a poorly developed channel. Much of the basin lacks an effective network of natural drainage channels, probably

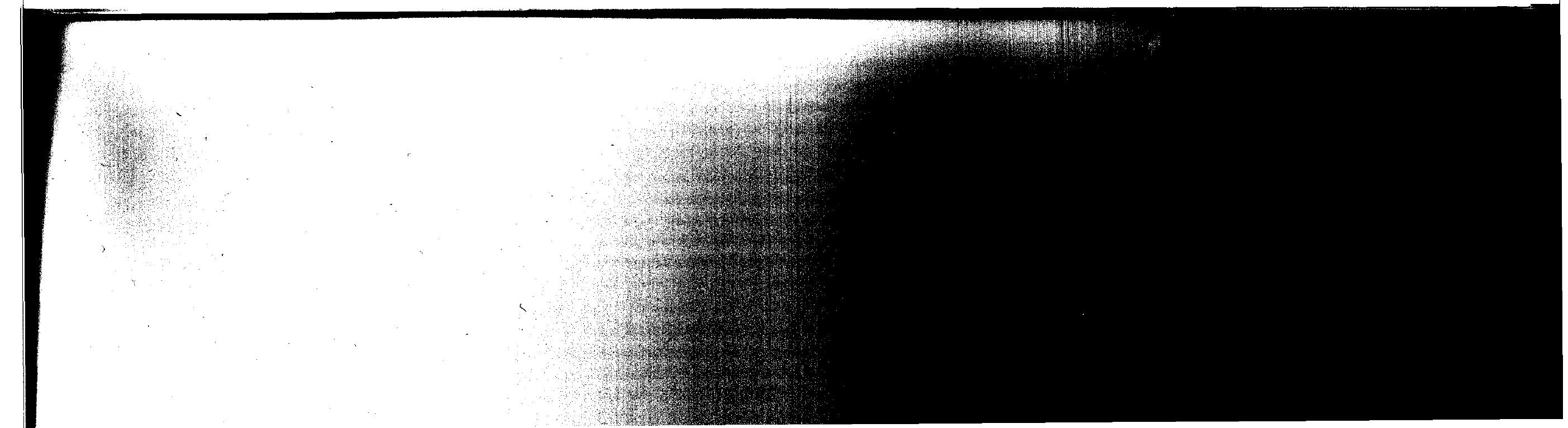


because most rainfall infiltrates the glacial sediments of the relatively young hummocky terrain. Many depressions contain swamps or bogs; however, water is commonly ponded during spring breakup or prolonged heavy rainfall in other depressions as well.

High flows in the few tributary channels in the study area are rare and may not occur even during the annual peak runoff. However, the main streams of Rabbit, Little Rabbit, and Little Campbell Creeks are subject to flooding during infrequent intense rainstorms and heavy snowmelt runoff over frozen ground.

In June 1964, severe flooding along Rabbit Creek caused damage to homes and to the Old Seward Highway. The magnitude of the peak flow is unknown. The accumulation of debris played a major role in the flooding by plugging culverts and impounding water that then overflowed streambanks (U.S. Army Corps of Engineers, 1973). The 1964 flood was reported to be caused by a breakout of water backed up by a snowslide in the drainage basin east of the study area.

The peak flow of a 100-year flood on Rabbit Creek has been estimated by the Corps of Engineers at $550 \mathrm{ft} 3 / \mathrm{s}\left(15.6 \mathrm{~m}^{3} / \mathrm{s}\right.$ or $355 \mathrm{Mgal} / \mathrm{d})$. A flood of this magnitude, called the Intermediate Regional Flood (IRF), has a 1 percent chance of occurring during any given year.

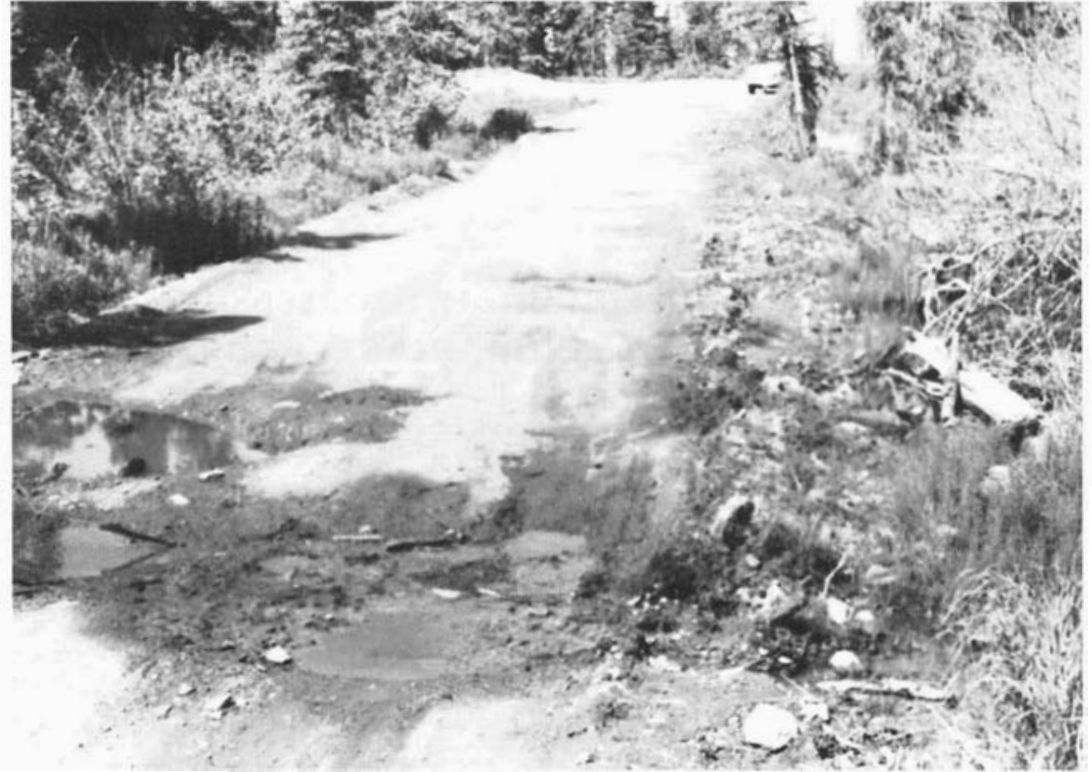

Figure 15.-- Ground-water seepage crossing road in upper O'Malley area.

This road was built alang a terrace and formed a barrier causing shallow ground water to surface. Water has ponded on the uphill side and flowed over the road. lcing problems at this sile are probable during the winter months.
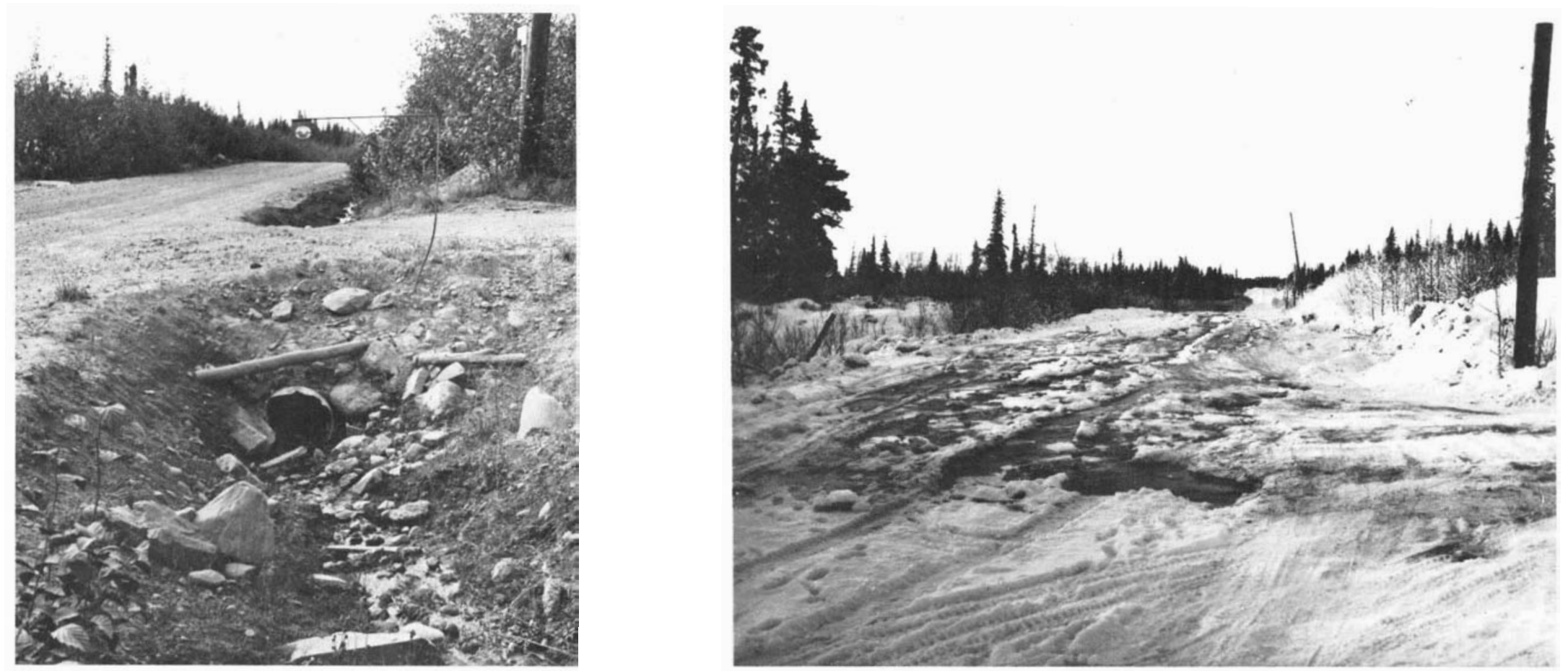

Figure 16.- Summer drainage and winter icing at Patrick Road and upper DeArmoun Road.

Year-round ground-water seepage from a nearby slope has caused a buildup of ice in the roadside ditch during winter months. This icing in December 1971 created impassable road conditions for several weeks. Excess water flowed over the

icing infiltrated the snow cover, and then seeped over the frozen ground into nearby yards. 


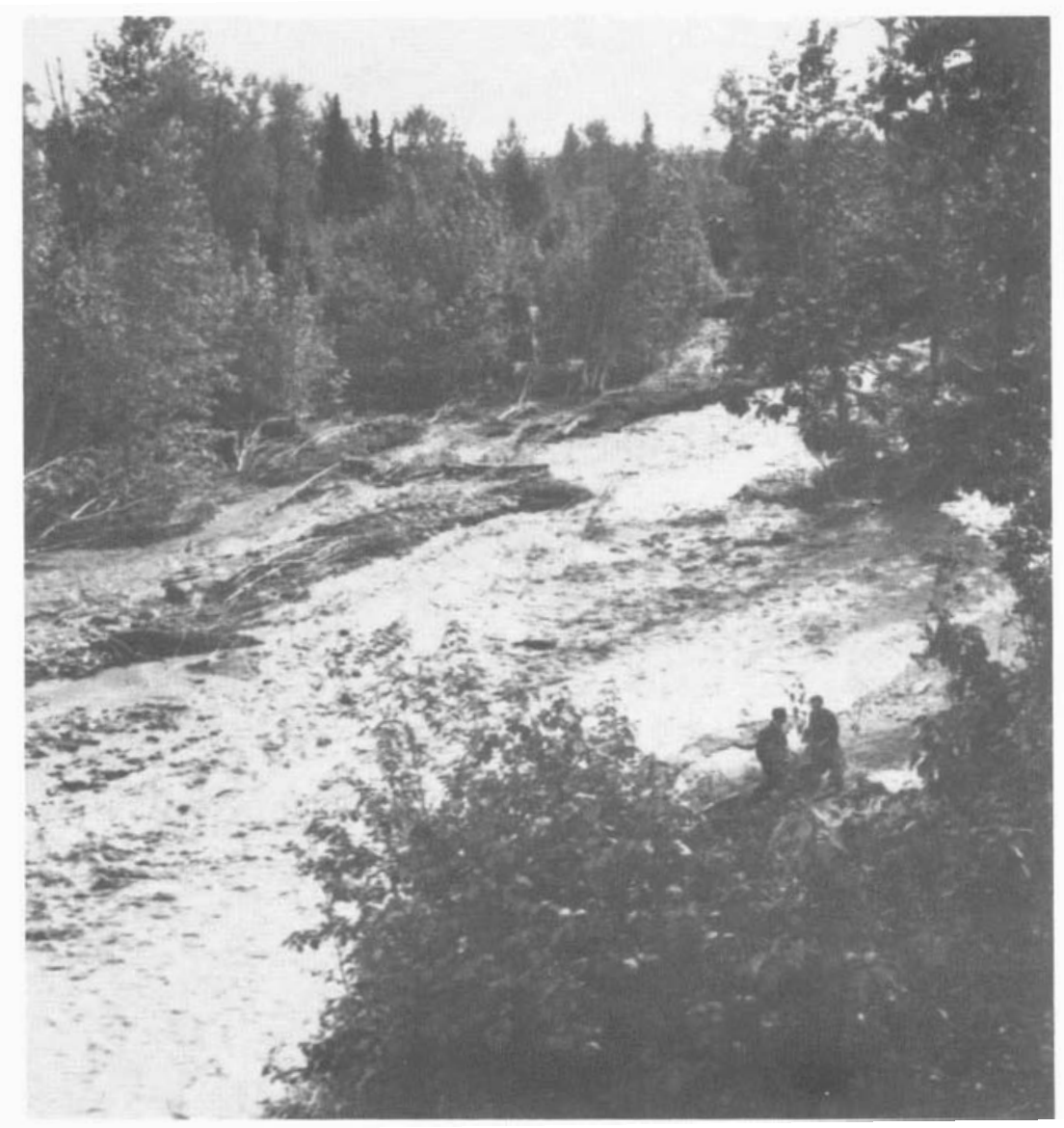

Figure 17.-- 1964 flood on Rabbit Creek.

The stream averflowed $i$ ts banks and caused uprooting of trees along the flood plain. In this vicinity a wooden

bridge was washed away. More severe floods than this are expected to occur.

Photograph courtesy of Ruth Brewster

Flood conditions have not occurred in recent years, and some residents have built on or very near the flood plain. The valley bottom of Rabbit Creek that would be inundated by the IRF has been mapped as a belt along the main channel mostly less than 50 $\mathrm{ft}(15 \mathrm{~m})$ wide (U.S. Army Corps of Engineers, 1973). The flood plain for the IRF could be wider than that mapped because of the likelihood of some backing-up of water by debris lodging in the channel (fig. 17). The magnitude of backwater effects cannot be determined beforehand.

At times during the winter, stream channels in the Anchorage area become extensively iced. In recent years, unseasonal winter rainstorms have not produced enough water to cause floodflow over the ice. Heavy rainfall and runoff could cause ice jams in channels and result in stream levels rising several feet higher than the peak water level of the same magnitude flood under ice-free conditions. Flooding could be increased further by rapid melting of a deep snow cover or by runoff resulting from an intense rainfall over bare frozen ground.

Flood-plain maps are not available for Little Campbell and Little Rabbit Creeks. The potential for flood damage probably is not as great on these streams as on Rabbit Creek because their drainage areas lying in mountainous terrain are much smaller. However, serious flooding could develop as a result of abnormally heavy rainfall, particularly if stream channels were heavily iced at the time.

The flood potential of smaller Hillside drainages and roadside ditches is now small but undoubtedly will increase with development of the area. Overland runoff into these channels will increase as the natural vegetation and topsoil is stripped and replaced by impervious surfaces. Peak flows can also be expected to increase if additional ditching and straightening of existing channels occurs. Commonly, as runoff becomes more rapid, the frequency of high flows increases. Storm discharges in channels will become flashy, banks will erode more rapidly, and streams will carry greater silt loads, causing the natural quality of these drainages to deteriorate.

Severe erosion of streambanks and roads during future floods on Rabbit and on Little Rabbit Creeks may result in additional risks to homes and private utilities (figs. 18 and 19). Many of these potential erosion problems could be minimized if erosion-control measures such as the use of vegetation, installation of storm-drainage systems, use of bank stabilization techniques, and provision for green belts along the major floodways were implemented. In addition, the construction of debris-collection basins along the major streams may prevent culverts and bridges from becoming. plugged and reduce backwater flooding during heavy rains.

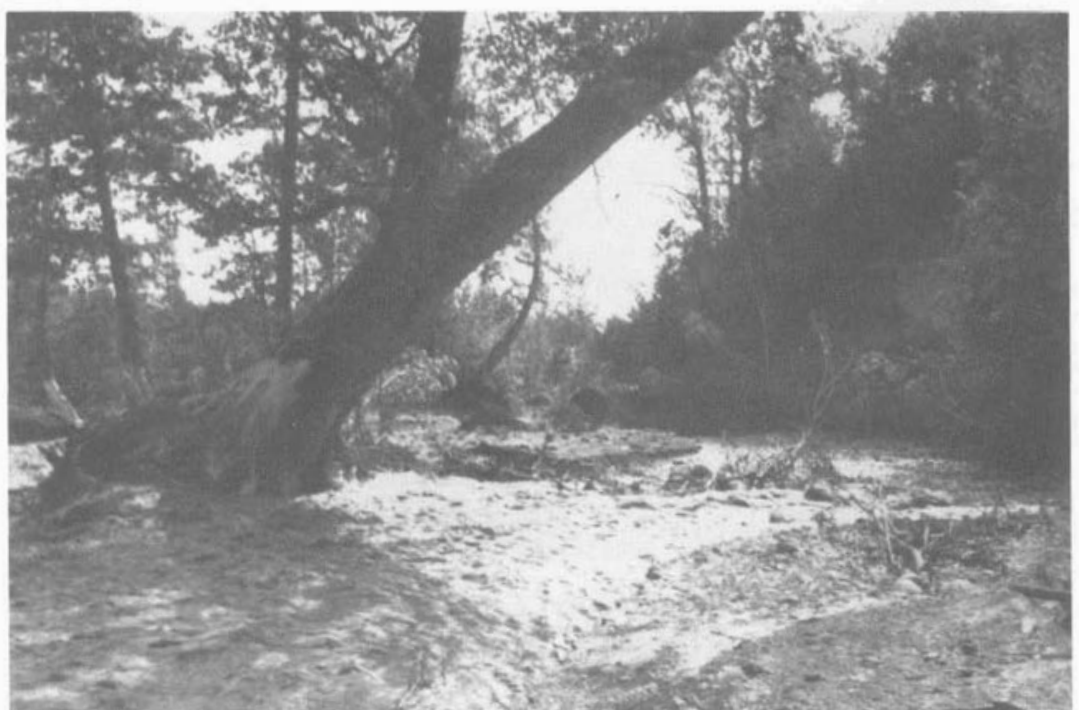

Figure 18.-- Streambed and bank erosion during 1964 flood A relatively steep channel in alluvial material allows Rabbit Creek to erode its banks rapidly during floods. Undermining of large trees by the shifting streamflow. increases the potential for clogging of the channel. Photograph courtesy of Ruth Brewster

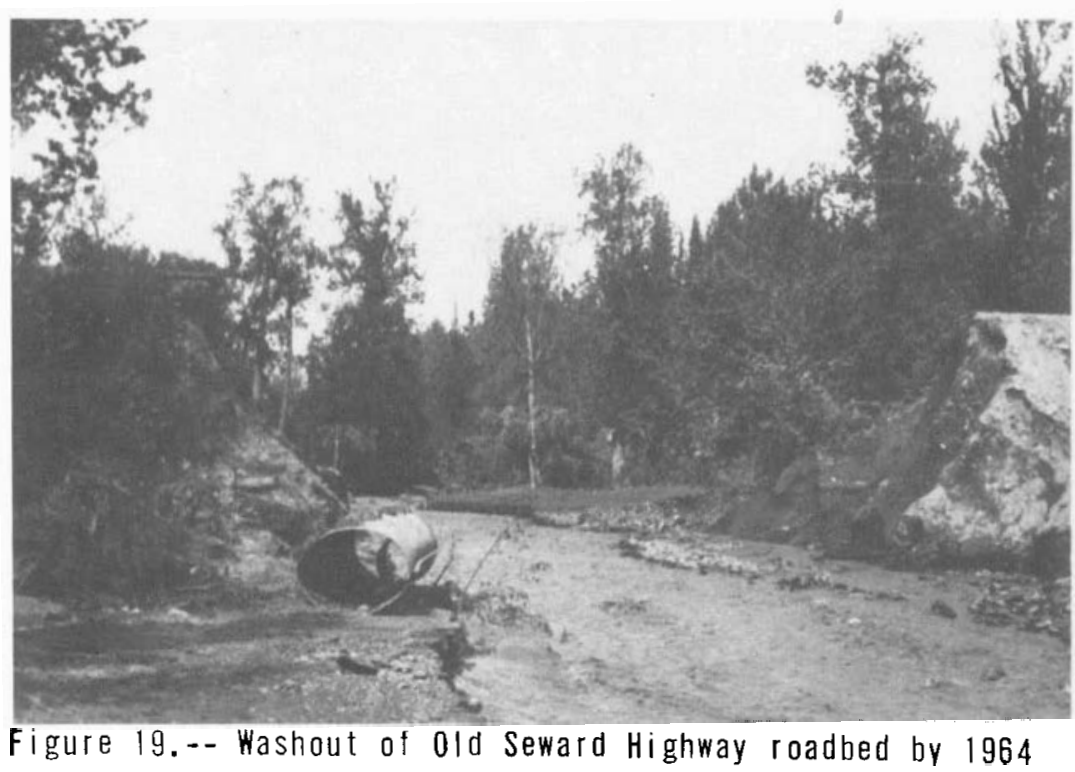

flood on Rabbit Creek.

Photograph courtesy of Ruth Brewster 
A small earth dam in the Hillside area failed in the spring of 1972 The earth dam was constructed in 1964 across the mouth of a swampy depression about three-fourths of a mile above Birch Road (NW1/4 sec. 23; fig. 3 ). Little Campbell Creek was partly diverted into the area, creating a 6 -acre $\left(0.02-\mathrm{km}^{2}\right)$ lake. When the dam failed, a flood of water discharged into the main channel of Little Campbell Creek (figs. 20 and 21). Driveways and culverts across the creek were washed out, and one child was drowned.

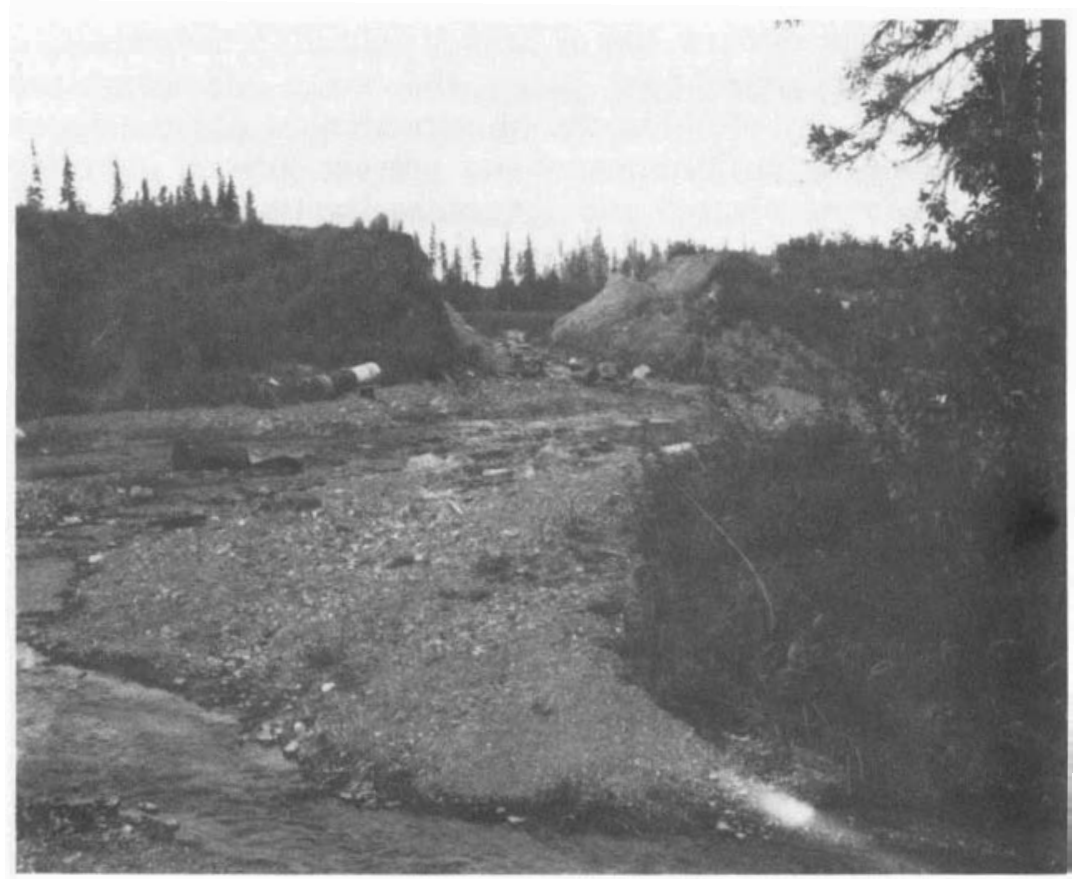

Figure 20.-- "Lake of the Hills" earth dam after failure in 1972.

The sudden discharge of water flooded into nearby Little Campell Creek and disrupted the natural channel. Photograph taken June, 1973 .

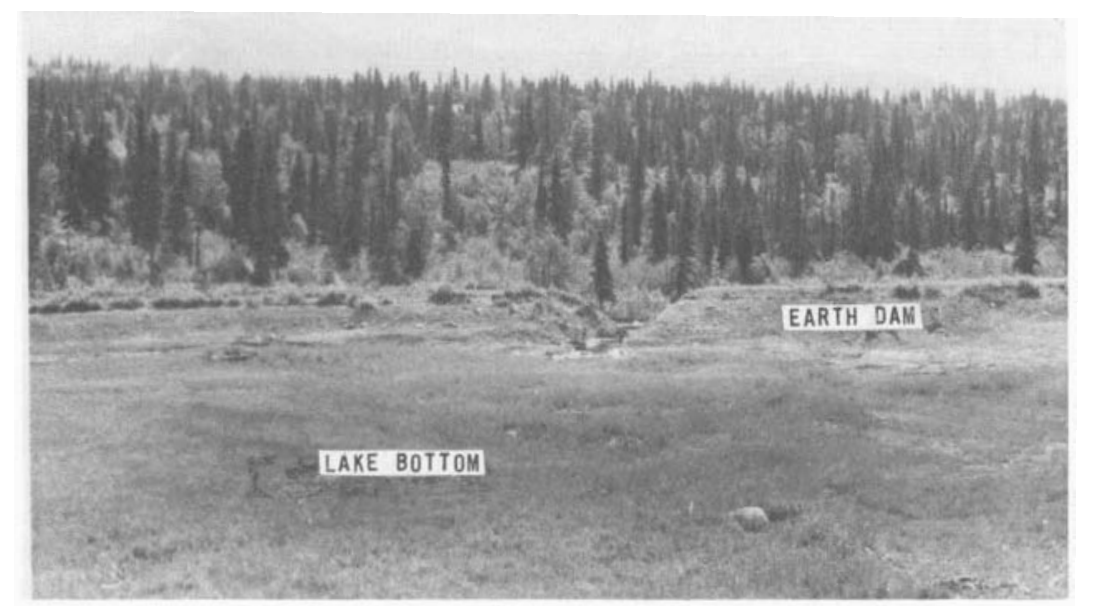

Figure 21.-- Remnant 'Lake of the Hiils' after 1972 breakout. Children fishing in Little Camphell Creek, which now flows across the dried lake bottom, indicate the size of the earth dam and impounded lake. Photograph taken June 1973; view to the south. 
- THE NATURAL QUALITY OF GROUND WATER AND WATER IN STREAMS AND LAKES IS GENERALLY GOOD. HOWEVER, INCREASED LAND DEVELOPMENT MAY CAUSE DEGRADATION OF WATER QUALITY IF POTENTIALLY HARMFUL PRACTICES ARE NOT RECOGNIZED BY PLANNERS AND AVOIDED BY DEVELOPERS.

- the MOST PERTINENT PROBLEM IS POLLUtion OF THE WATER RESOURCES BY DISCHARGE FROM SEPTIC-TANK SYSTEMS. IN PLACES POLLUTION HAS IMPAIRED WATER QUALITY CHEMICALLY OR BACTERIOLOGICALLY AND CONSEOUENTLY HAS RESULTED IN A HAZARD TO PUBLIC HEALTH; THIS CONDITION IS CALLED CONTAMINATION. ALTHOUGH THE PRESENT POPULATION DENSITY IS LOW, SOME STREAM WATER IS ALREADY UNSAFE TO DRINK. FAILURE OF PRIVATE SEPTIC SYSTEMS HAS CAUSED POLLUTED WATER TO SEEP TO THE SURFACE AT SOME SITES, AND THIS CAN CONTAMINATE NEARBY DOMESTIC WELLS.

- IF THE PRESENT TREND OF SUBDIVISION DEVELOPMENT CONTINUES, THE DENSITY OF RESIDENTIAL SEPTIC SYSTEMS COULD INCREASE THREE- OR FOUR-FOLD BEFORE PUBLIC SEWERS BECOME AN ECONOMIC POSSIBILITY. UTILIZATION OF HYDROLOGIC DATA WOULD RESULT IN LESSENING THE CHANCES OF POLLUTION FROM SEPTIC-TANK SYSTEMS

The Natural Quality of Hillside Area Water

\section{Ground Water}

Ground water at present is generally of good potable quality, although in places water from wells may require treatment to remove iron or to reduce hardness. Appendix A-4 shows the concentrations of the common water-quality constituents in samples obtained from 12 Hillside wells. These wells and additional wells where some chemical information was obtained are shown in figure 22

Most ground water in the area is of the calcium bicarbonate type and is moderately hard. A comparison of data in appendix A-4 shows that the concentrations of all constituents, except iron, are within the maximum recommended limits for drinking water set by the Environmental Protection Agency (1972) and the U.S. Public Health Service (1962).

The concentration of iron in water from more than one-third of the wells sampled was in excess of $0.3 \mathrm{mg} / \mathrm{l}$ (milligram per litre) and several wells had concentrations of five times this amount. If these samples are typical of ground water in the Hillside area, high dissolved-iron concentrations may be widespread. Ground-water quality problems occur more frequently in the Rabbit and Little Rabbit Creek drainage basins where wells tap bedrock or sedimentary aquifers immediately above bedrock. High iron concentrations are more likely to be found in ground water obtained at depths of more than $200 \mathrm{ft}(61 \mathrm{~m})$ below land surface in both unconsolidated sediments and in fractured bedrock. Unless special water conditioners are used to remove most of the iron, homeowners may experience objectionable iron staining of clothing and appliances.

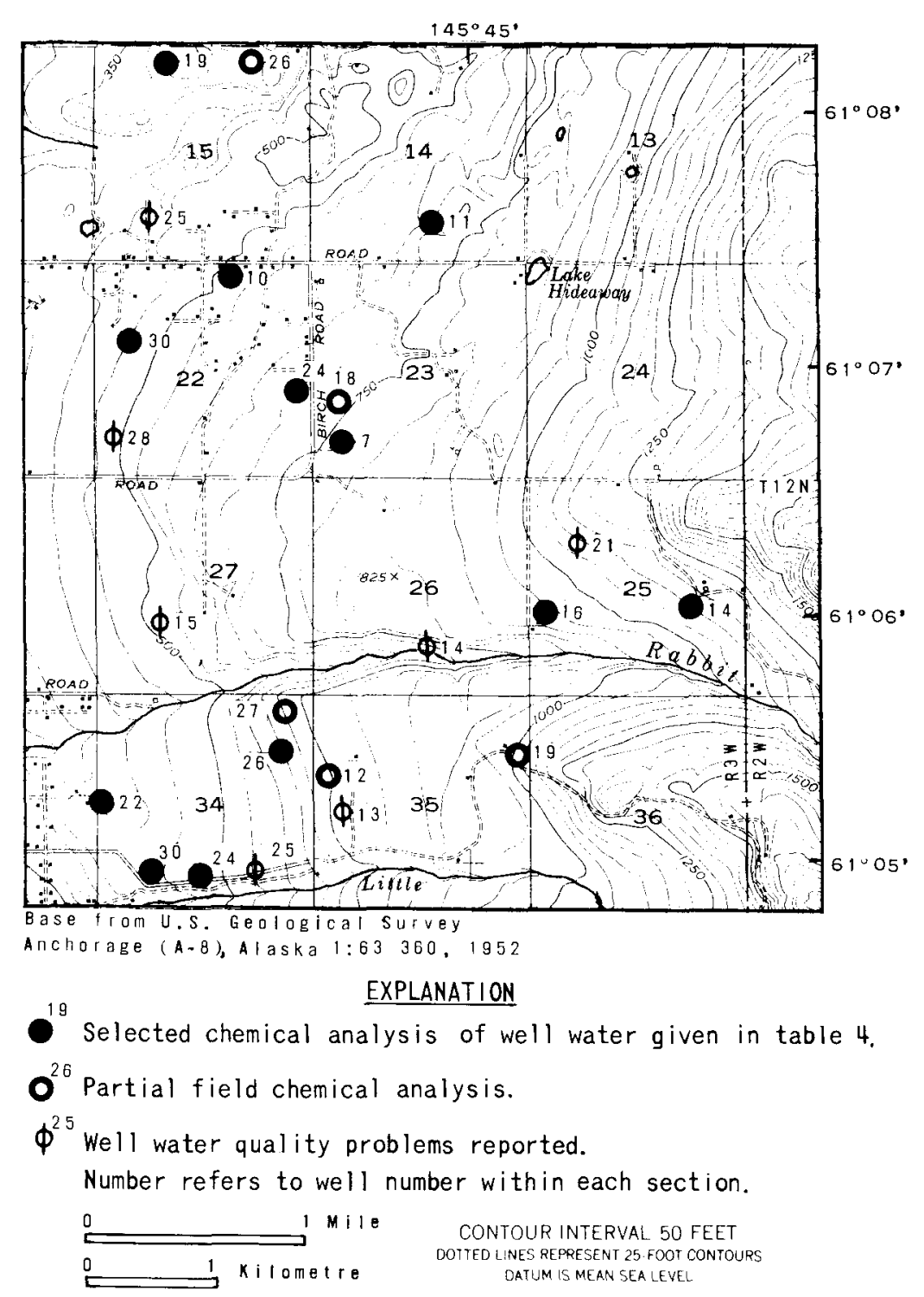

Figure 22.-- Sampling sites for ground-water quality analyses. 
Ground water in the Hillside area commonly is also high in carbonate hardness (the hardness as $\mathrm{CaCO}_{3}$ exceeds $100 \mathrm{mg} / \mathrm{l}$ ). All but one of the chemical analyses in appendix $A-4$ show a hardnes that approaches or exceeds this amount. Again, the data show that deep wells, especially those tapping bedrock, tend to produce harder water. Residents may find that a water conditioner is worthwhile in reducing soap consumption and in preventing formation of carbonate scale in water pipes. However, for health reasons some people should not drink the high sodium content water produced by some conditioners.

The temperature of Hillside ground water averages about $37^{\circ} \mathrm{F}$ $\left(3^{\circ} \mathrm{C}\right)$. It is similar to the temperature of ground water throughout the Anchorage area and, although low, presents no problems for residential use.

\section{Surface Water}

The natural quality of surface water in lakes and streams is good. The water is soft to moderately hard and meets public health drinking water standards for chemical constituents. However, high bacteria counts indicate that most surface water probably is unsafe to drink without treatment. Generalizations made concerning the concentration of chemical constituents and bacteria in this report are based on a small number of samples (fig. 23; appendix A-5). Stream samples taken in April 1972 and 1973 represent low-flow conditions because no snowmelt runoff had occurred prior to sampling. All other samples were collected when streamflow was more than base flow but less than high flow.

An appreciable increase in the concentrations of various chemical constituents in Lake Hideaway, such as dissolved solids, is suggested by two water analyses taken 6 years apart. However these two samples may not be representative, and additional samples would need to be obtained to verify the apparent change. Septic-tank effluent may eventually contribute undesirable materials to a lake even if seepage pits are constructed in earth materials that are highly suitable for effective drainage (Rickert and Spieker, 1971). The water table in the vicinity of Lake Hideaway is near the surface, and the lake is fed by ground-wate seepage. Consequently, it is probable that effluent from seepage pits constructed in the surficial glacial alluvium (fig. 5) upgradient from the lake may mix with the shallow ground water and enter the lake.

State and Federal agencies have set maximum concentration levels for several types of bacteria for the various uses of water. The sanitary quality of drinking water is commonly determined by relating the concentration of total coliform and (or) fecal coliform bacteria groups to established standards. The concentration of bacteria from either group can be used to estimate the probability of the presence of disease-causing bacteria, or pathogens. Pathogens originate in the feces of warm-blooded animals, including man, and may survive in streams for miles beyond their point of injection.

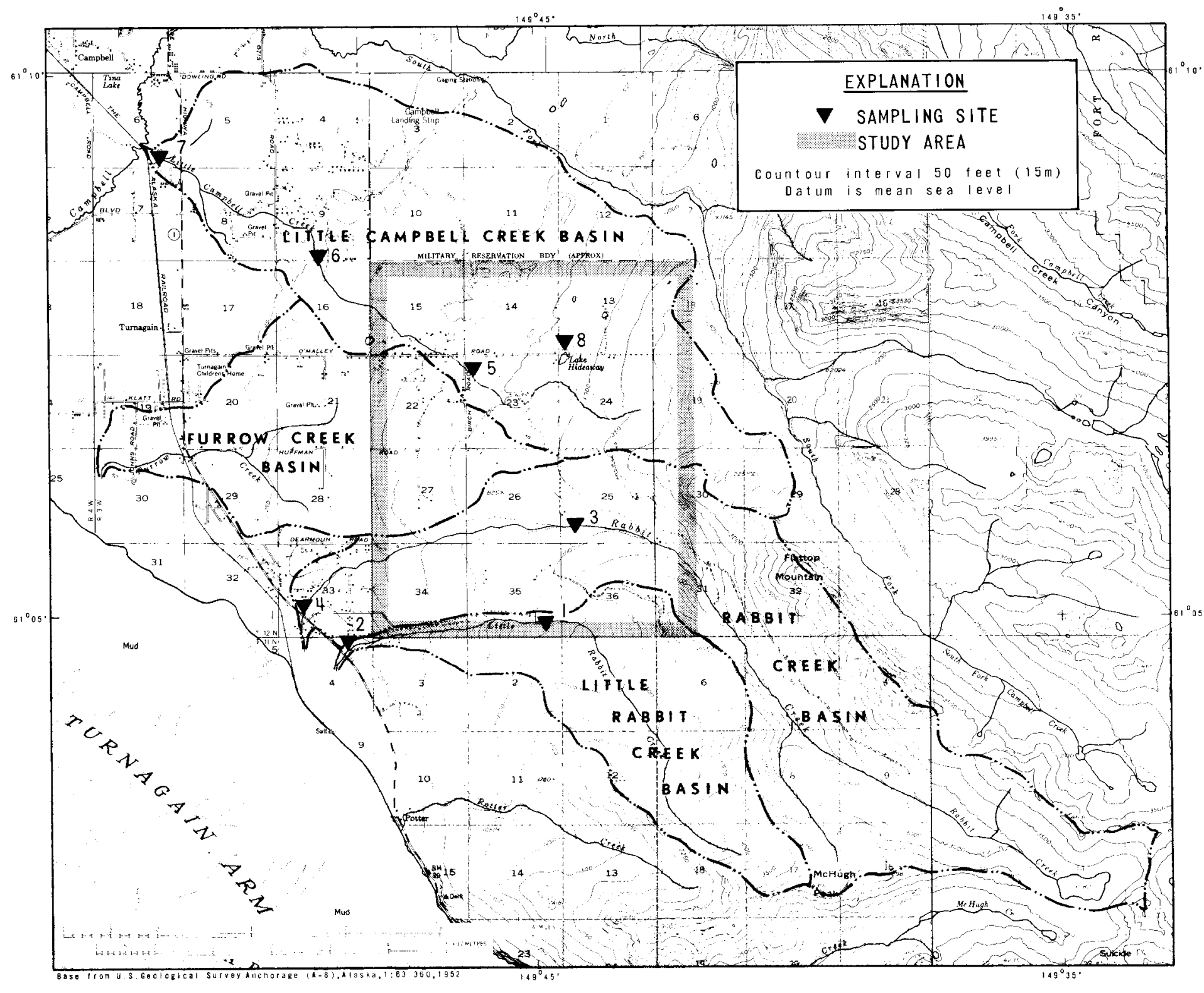

Figure 23.-- Sampling sites for surface-water quality analyses. 
Analyses for total coliform bacteria counts in samples taken during low-flow conditions in April 1973 showed that these microorganisms were present at all seven stream sites (appendix A-5). These total coliform counts do not necessarily imply fecal pollution because the observed coliform organisms could have originated from nonfecal sources, such as soil.

However, at a few sites, the high counts of total coliform organisms strongly suggest that the water may have been fecally polluted. Total coliform concentrations of more than 2,400 MPN (most probable number of organisms in 100 millilitres of water) were found in stream water collected near the mouths of Little Rabbit and Little Campbell Creeks (fig. 23, sites 2 and 3) in 1973. More specific data are needed on these creeks. According to State water-quality standards ${ }^{\mathbf{1}}$, water is unsuitable for irrigation, livestock, and human contact when the MPN count of more than 20 percent of the samples exceeds 2,400 total coliform organisms.

At all other sites, except site 6, the MPN count of total coliform organisms was less than 50 , the maximum allowable concentration for class $\mathrm{A}$ water. Class A water requires only simple disinfection treatment, such as boiling, to meet State standards.

Total coliform concentrations of less than 50 MPN are thought to be within the range of background contamination from wildlife and other sources, and, therefore, pathogens from human wastes probably are absent (Kyle Cherry, Alaska Dept. of Public Health, oral commun., 1973). The low total coliform concentrations observed at upstream sampling sites suggest that the high concentrations at downstream sites may reflect fecal pollution.

No conclusions can be drawn at this time about the presence of pathogenic organisms in Hillside streams. MPN determinations made during low flow in April are valuable in detecting inflow of polluted water, but these results probably are not representative of conditions during high runoff periodsor during warm months. A series of samples taken during critical flow conditions over a period of several years would determine: (1) the presence of fecal coliforms and their concentrations, (2) the effect of heavy storm runoff on fecal coliform concentration, and (3) the long-term trends of fecal coliform concentrations in streams where pollution is identified.

Other important water-quality parameters are temperature and sediment transport. The available stream data define a temperature range from $32^{\circ} \mathrm{F}\left(0^{\circ} \mathrm{C}\right)$ in the winter to $43^{\circ}-46^{\circ} \mathrm{F}$ $\left(6^{\circ}-8^{\circ} \mathrm{C}\right)$ during summer months. Definitive data are not available on the sediment concentration in Hillside area streams. However, visual inspection of these streams under natural conditions suggest an insignificant suspended-sediment load except during periods of high flow.

Figure 24.-- Ground water flowing through partly buried septic tank.

In this steep-sloped locality shallow ground water creates adverse conditions for the use of septictank systems.

Photograph courtesy of Greater Anchorage Area Borough 'State of Alaska, Title 18, Environmental Conservation, chap. 70, Water Quality
Susceptibility of Water Resources to Pollution from Onsite Sewage Disposal

The Hillside area is developing rapidly from a rural homestead area to a suburban community. However, waste-disposal practices have not changed, and in 1972 about 1,000 families were using individual onsite septic-tank systems within the study area. The density averages about one system per 9 acres $\left(0.04 \mathrm{~km}^{2}\right)$; however, density varies with development and in section 15 there is one waste-disposal system per 4 acres $\left(0.02 \mathrm{~km}^{2}\right)$ of land.

As septic system density in the study area increases, effluent will increase the rate of recharge to the areal ground-water body. A future population of 10,000 people in the study area may require as many as 3,000 systems, or one system per 3 acres $\left(0.012 \mathrm{~km}^{2}\right)$. The total daily discharge of these systems probably would increase from the current estimated 0.4 million gal $\left(1,500 \mathrm{~m}^{3}\right)$ to about 1.2 million gal $\left(4,500 \mathrm{~m}^{3}\right)$. This increase represents an average distribution of about 130 gal (492 l) of septic wastes per day on each acre of the study area. If the water supply continues to be obtained from local wells, the supply will be in part recycled by the residents. Analysis of the water budget (fig. 12) indicates that ground-water recharge from precipitation is between 300 and 700 gal $(1,140$ and 2,650 I ) per day per acre. If it is assumed that al effluent percolates to the ground-water body, a density of one system per 3 acres $\left(0.012 \mathrm{~km}^{2}\right)$ will increase local recharge by 19 to 43 percent. If development density reaches one system per acre, local recharge will be increased 56 to 130 percent and total septic system discharge may be as much as $3.6 \mathrm{Mgal} / \mathrm{d}\left(0.16 \mathrm{~m}^{3} / \mathrm{s}\right)$ in the study area. Present land-use trends indicate that these systems will not be evenly distributed. Consequently, pollution problems may result where high septic-tank density coincides with areas where the susceptibility of the physical environment to pollution is high (fig. 24).

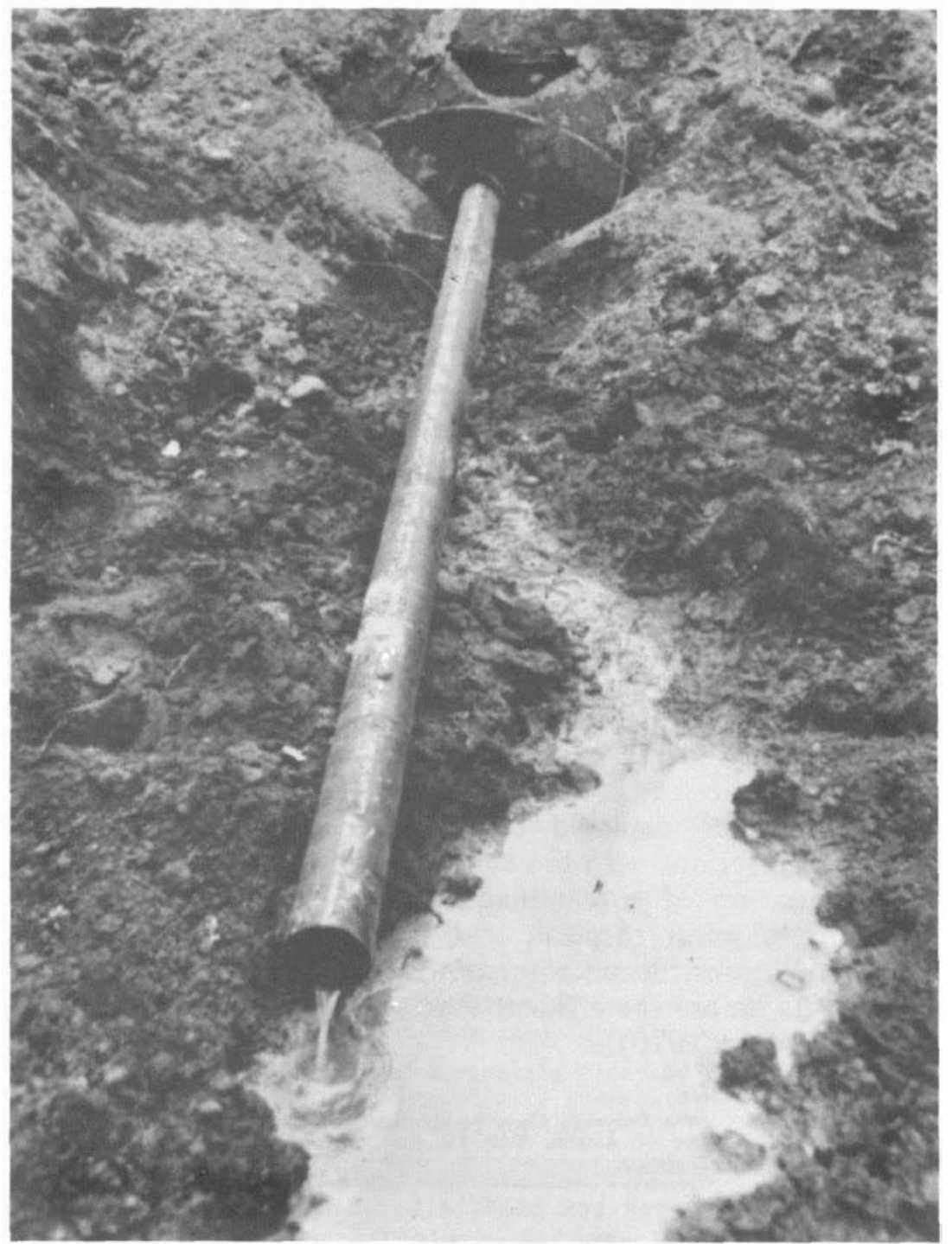



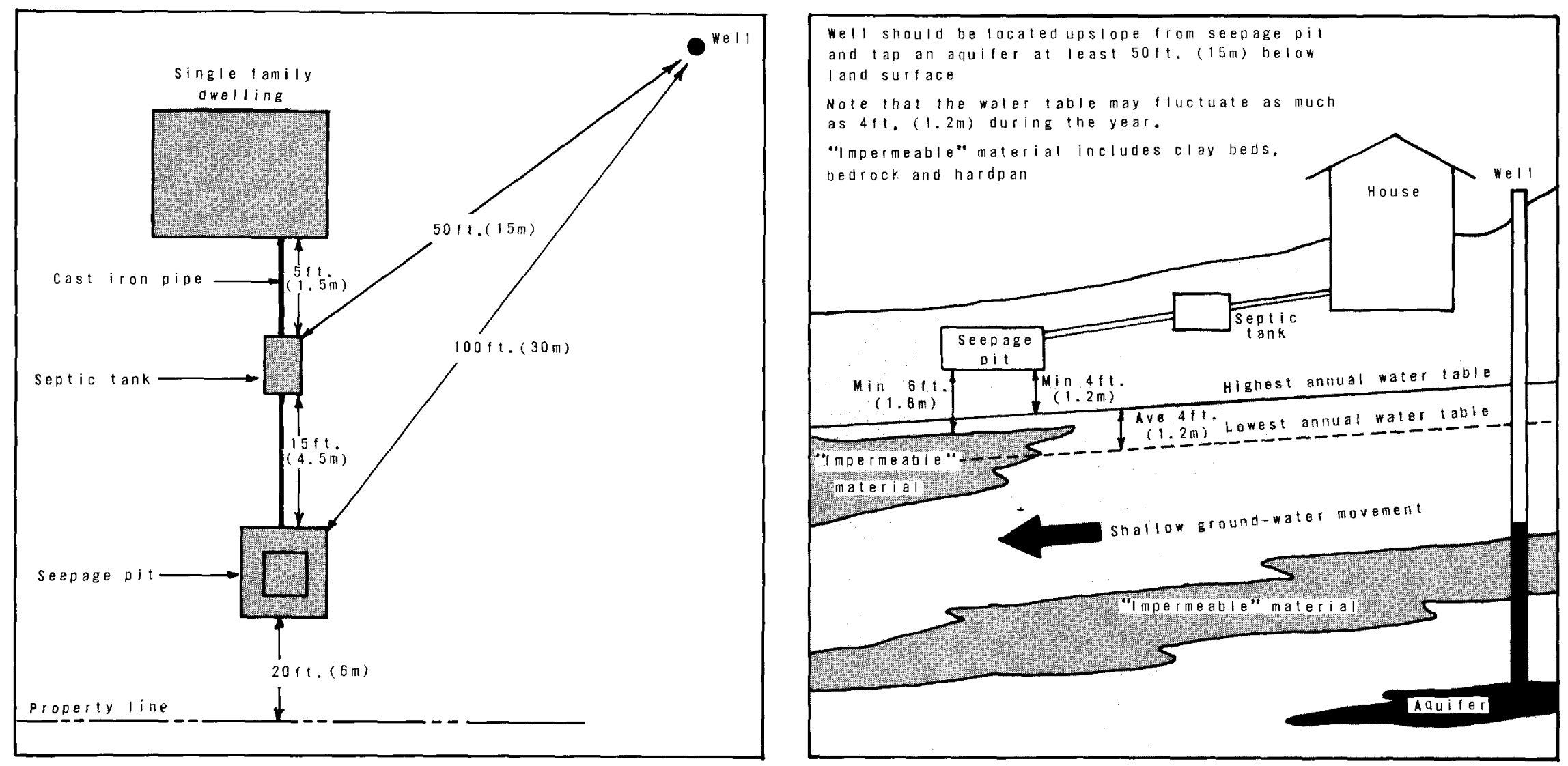

Figure 25.-- Minimum requirements for sewer and water systems for single family residences in the Greater Anchorage Area Borough.

\section{Environmental Considerations of Septic-tank Systems}

In recognition of the potential for ground-water pollution from sewage-disposal systems, the Borough and State governments have established the regulations ${ }^{1}$ shown in figure 25 . A further stipulation requires that before subdivision approval, earth materials must be tested in place at the site to define the absorptive capacity at proposed seepage-pit sites.

The following discussion is based on the legal requirements cited above and on documented studies made outside Alaska. The authors emphasize that the statements made in the following paragraphs represent the best available estimates of knowledgeable hydrologists and sanitarians. These generalities are offered as guidelines for areawide planners. A detailed field investigation of most Hillside sites would be required to assure that disposal of wastes at that location will not, in fact, cause pollution.

In the Hillside area, waste-disposal regulations require that sewage be piped into a septic tank before passing into a porous-walled seepage pit. In the septic tank the solids and liquids are detained so that biological processes can decompose the mixture. A residual liquid then overflows into the seepage pit where it infiltrates through the walls into the surrounding earth materials and moves downward under the force of gravity and laterally by capillary forces.

Septic-tank effluent has a high pollution potential because many chemicals and most detergents and viruses are not decomposed or removed in the septic tank. After the effluent flows from the seepage pit into earth materials, the chemical and biological contaminants are depleted or changed through chemical and physical interactions with the subsurface environment. Reduction in concentration of contaminants in the effluent is principally caused by physical sorption and by chemical dilution. Under certain conditions, decontamination of the waste water may not be complete before the effluent reaches shallow aquifers or water wells (Schneider, 1970). 1 Greater Anchorage Area Borough Code of Ordinance 28-68, Article 6, Sewage
Disposal Practices; State of Alaska, Titte 18, Environmental Conservation, chap. 72, wastewater Disposal.
Additional treatment of effluent from septic tanks depends on the reactivity of subsurface materials at ambient temperatures and the rate of movement in these materials. The principal geohydrologic characteristics that determine the effect of infiltrating pollutants on ground water in the Hillside area are:

1. Depth to the water table.

2. Thickness of unconsolidated sediments overlying bedrock.

3. Distance to surface-water bodies.

4. Permeability and sorptive capacity of surficial earth materials.

Slope of the land surface in disposal area.

6. Frozen ground or depth of seasonal frost.

In figure 26 these characteristics are considered as independent variables that either aid or impede the cleansing and purifying of the effluent as it moves through the soil. The significance of each is briefly discussed in the following paragraphs.

The depth to the water table and the thickness of unsaturated sediments overlying bedrock or a relatively impermeable stratum are critical factors that largely determine how rapidly the percolating effluent will reach the ground-water body. Attenuation of contaminants increases with the time of travel through sedimentary materials. In the unsaturated zone biologic processes and adsorption tend to accelerate attenuation. In this zone riuch of the effluent will be absorbed by earth materials and widely dispersed by capillary forces to satisfy moisture deficiencies in the sediments. Whereas most of the effluent eventually reaches the water table in flat terrain, a significant quantity may move laterally to the surface downslope from seepage pits in foothill environments. Here, shallow clay and dense till lenses may cause the effluent to be perched above the water table. Ultimately, transpiration by plants and surface evaporation in the summer may be an effective mechanism for dissipating much of the effluent in these localities. 
In subsurface environments of glacial sedimentary origin, granular earth materials are capable of removing many potential pollutants, including bacteria, within 10 to $20 \mathrm{ft}(3$ to $6 \mathrm{~m})$ of travel. However, chloride, nitrate, and other chemicals have been found to move with water percolating through unconsolidated sediments to greater depths (Crosby and others, 1968; McGaughey and Krone, 1967). Fecal bacteria, viruses, and some chemicals may travel much farther in coarse sand and gravel strata under aerobic conditions than in fine-grained sediments which are more anaerobic. In coarse-grained materials, nutrients and bacteria have been found at depths of $40 \mathrm{ft}(12 \mathrm{~m})$ (Franks, 1972; Bouma and others, 1972).

State and Borough regulations require a minimum of only $4 \mathrm{ft}$ (1.2 $\mathrm{m}$ ) of material between the bottom of a seepage pit and the wate table, and $6 \mathrm{ft}(2 \mathrm{~m})$ between pit bottom and bedrock (see fig. 25). But, data from a number of studies suggest that the minimum safe distance needed to reduce coliform bacteria in waste water to acceptable concentrations is more likely two or three times these distances. If fecal coliform organisms and viruses reach the ground-water body, they may move with the normal ground-water flow for hundreds of feet and enter pumped wells.

Commonly, septic-tank systems with seepage pits in the Hillside area discharge waste water into the earth about $10 \mathrm{ft}(3 \mathrm{~m})$ below the land surface to avoid seasonally frozen ground. Where the
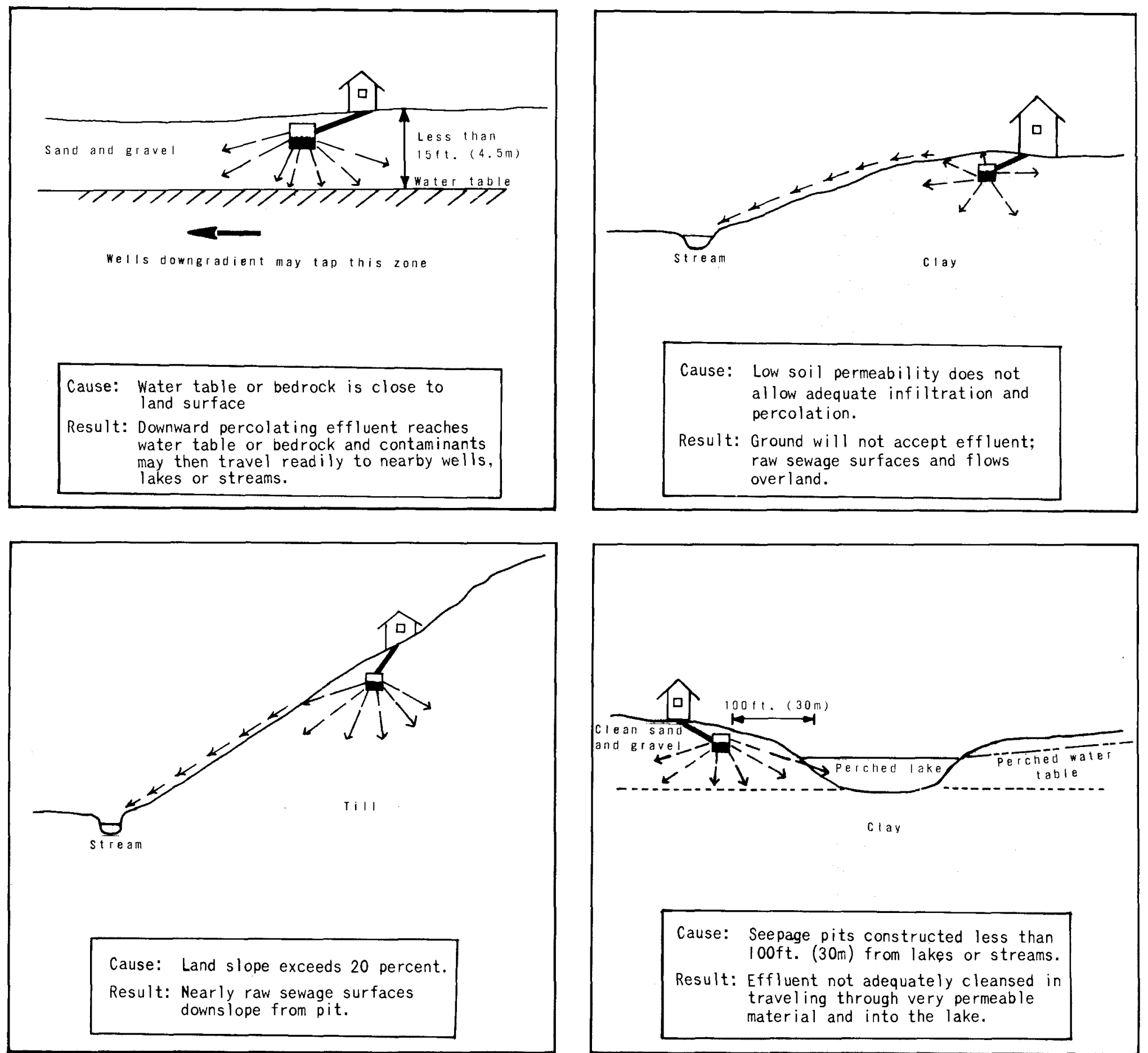

water table and bedrock are more than about $25 \mathrm{ft}(7.5 \mathrm{~m})$ below the surface, protection of ground water from serious pollution appears reasonably assured, except where highly permeable gravel is the only percolation medium. There is a high probability of ground-water contamination where either the water table or bedrock lies between 15 and $25 \mathrm{ft}(4.5$ and $7.5 \mathrm{~m})$ below the surface. If septic-tank systems are installed where either the water table or bedrock surface is less than $15 \mathrm{ft}(4.5 \mathrm{~m})$ below the surface, ground-water contamination is a strong possibility.

Where a seepage pit is constructed in saturated material, the effluent may overflow the pit and eventually rise to the surface (fig. 27). This occurs where the capacity of the material to transmit water is too small to allow the dispersion of septic-tank discharge. Contaminants in the effluent also mix with and pollute the shallow ground water surrounding the seepage pit.

Contaminated effluent probably will find its way into bedrock fractures if seepage pits are constructed in sediments that are only $15 \mathrm{ft}(4.5 \mathrm{~m})$ thick or less. Where fractures in the bedrock contain ground water, pollution may spread rapidly and wells tapping fractures more than 1 mile $(1.6 \mathrm{~km})$ away may pump contaminated water in a relatively short time after the effluent reaches bedrock. 


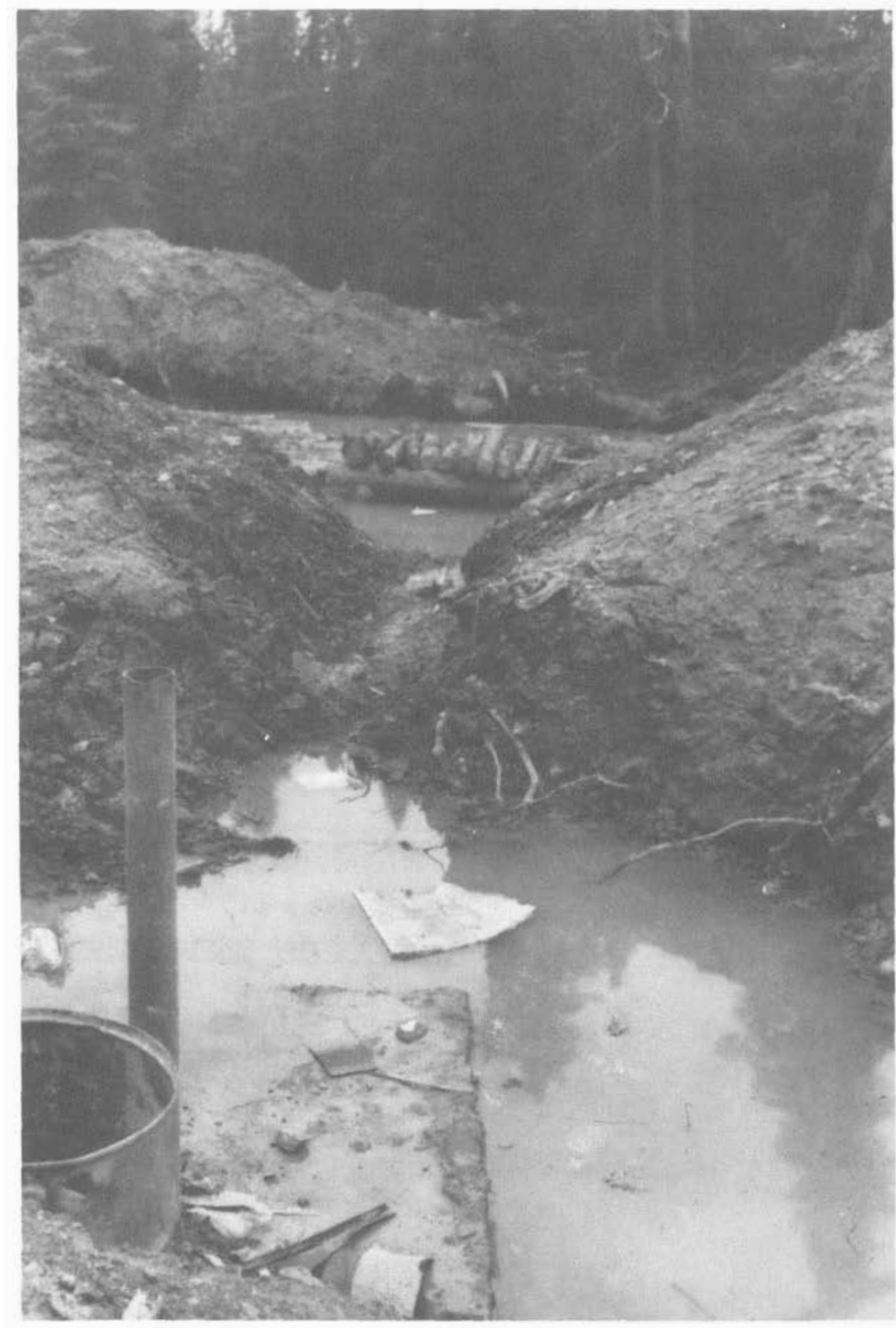

Figure 27.-- Cesspool cribbing floating in shallow ground water.

Pollution of ground water is imminent where household wastes are injected directly into saturated soils. In this type of installation, raw sewage would probably back up and overflow at the surface due to the inability of the effluent to disperse effectively. During winter months the water table may drop enough to allow freezing around a shallow disposal pit and result in a sewage back-up.

Photograph courtesy of Greater Anchorage Area Borough

Pollutants may reach and move into bedrock where waste water is discharged into sediments that range from 15 to $25 \mathrm{ft}$ ( 4.5 to 7.5 $\mathrm{m}$ ) thick. In these situations the probability of ground-water pollution is largely dependent upon the permeability and sorptive capacity of the sediments, and ranges from low to moderate.

The element of probability due to the depth to the water table in relation to the bedrock may be explained by comparing two sites where the thickness of unsaturated sediments is identical. Disposal of polluted waste water at the site where the water table lies above the bedrock surface poses less risk than at the site where the water table is below the bedrock surface. At the former site pollutants will be diluted and generally move slowly downgradient near the surface of the ground-water body while further attenuation occurs. In contrast, at the latter site pollutants may move rapidly downward in bedrock fractures to well intakes as less dilution and travel time results in less attenuation.
The distance to surface-water bodies is a factor because of the possibility of lateral migration of waste water either in local perched zones above the water table or in the saturated zone. Greater Anchorage Area Borough regulatory ordinances specify that the minimum distance between a water well, lake, or stream and a seepage pit will be $100 \mathrm{ft}(30 \mathrm{~m})$. However, the potential for pollution is high at greater distances where saturated well-sorted gravel occurs at shallow depth. Franks (1972) reported that biological pollutants traveled as far as $232 \mathrm{ft}(71 \mathrm{~m})$ in such strata.

Permeability and sorptive capacity, which are determined by the size and shape of sediment particles, are also critical characteristics of the shallow subsurface environment. Permeability and sorption generally are inversely related. Fine-grained materials have a much greater sorptive capacity than coarse-grained materials; however, the smaller the grain size the less the permeability of a material. Clays have the highest sorptive capacity because the vast surface area their particles provides for adsorption, but they also have extremely low permeability. Clean, well-sorted gravels have the highest permeability, but they lack the sorption and filtering capacities needed to adequately cleanse septic-tank effluent.

The optimum earth material in which to place a seepage pit is a moderately permeable material which permits percolation and drainage and also provides maximum sorption as well. Uncemented clayey or silty sand and gravel, typically found in glacially derived deposits, provides adequate treatment of septic-tank effluent if the sediments are unsaturated and aerobic conditions prevail. Thus, maximum attenuation of pollutants occurs as the effluent moves slowly away from the pit walls. Metamorphic bedrock, which is relatively impermeable and lacks sorptive capacity except where weathered, provides inadequate treatment of septic-tank effluent. If the metamorphic rocks are not fractured, very little drainage takes place; if fractured, effluent is transmitted rapidly to the zone of saturation.

Where the slope of the land surface exceeds 20 percent $(5: 1$ slope), the successful operation of septic-tank systems is unlikely. Effluent probably will flow to the surface downhill from seepage pits regardless of the permeability of the earth material and depth of the seepage pit bottom (Franks, 1972). As the slope of the land increases, the distance that the effluent travels through the earth materials before reaching the surface decreases. Thus, the volume of material that is effective in the adsorption and filtering processes also decreases, and seepage at the surface may contain a high concentration of contaminants.

In the design and location of road cuts on slopes, the possibility of intersecting strata containing dispersed effluent should be considered. Seepage pits located a short distance upslope from existing road cuts may constitute a serious pollution hazard because many Hillside road cuts intercept ground water or intermittent springs that flow during periods of rapid snowmelt or heavy rain.

Seasonally frozen ground, or the formation of seasonal frost, may strongly influence the movement of liquid waste. In the Hillside area frost commonly penetrates to depths of 8 to $10 \mathrm{ft}$ (2.5 to 3 $\mathrm{m})$, and effluent may freeze and retard normal dispersion. Upward moisture movement in the vapor phase toward surficially frozen soil due to vapor pressure differences has been reported by several investigators (Ferguson, Brown, and Dickey, 1964, and Harlan, 1972). Taylor and Cary (1965) indicate that the force acting to move liquid water in soil resulting from temperature gradients may be many times greater than that of gravity. Under these conditions effluent may become frozen in the soil near the surface during late winter and early spring months. When this upward displaced effluent is freed by spring thaw, there is an increased possibility of polluted water migrating laterally and joining any nearby surface seeps. 
Table 3.-- Numerical rating for determination of pollution susceptibility of water resources.

\begin{tabular}{|c|c|c|c|}
\hline $\begin{array}{l}\text { Geohydrologic } \\
\text { characteristic }\end{array}$ & \begin{tabular}{c|} 
Map \\
symbol
\end{tabular} & $\begin{array}{l}\text { Rating } \\
\text { points }\end{array}$ & Field condition \\
\hline Depth to ground water & W & 20 & $\begin{array}{l}\text { A11 land that is swampy or waterlogged, or where the water table is less than } \\
15 \mathrm{ft}(4.5 \mathrm{~m}) \text { in depth. }\end{array}$ \\
\hline \multirow{5}{*}{$\begin{array}{l}\text { Distance to surface- } \\
\text { water bodies }\end{array}$} & \multirow{5}{*}{ D } & 11 & A11 land where ground water occurs at depths of $15-25 \mathrm{ft}(4.5-7.5 \mathrm{~m})$. \\
\hline & & 20 & A11 land within $100 \mathrm{ft}(30 \mathrm{~m})$ of lakes, ponds, and streams. \\
\hline & & 7 & A11 land within $100-200 \mathrm{ft}(30-61 \mathrm{~m})$ of lakes, ponds, and streams. \\
\hline & & 1 & A11 land within 200-300 ft (61-91 m) of lakes, ponds, and streams. \\
\hline & & 0 & A11 land more than $300 \mathrm{ft}(91 \mathrm{~m})$ from lakes, ponds, and streams. \\
\hline $\begin{array}{l}\text { Permeability and } \\
\text { sorptive capacity } \\
\text { of surficial material }\end{array}$ & \multirow[t]{3}{*}{ P. } & $\begin{array}{l}20 \\
12\end{array}$ & $\begin{array}{l}\text { Bedrock, generally impermeable. Very low sorptive capacity. } \\
\text { Lake and pond deposits; mostly silts and clays of low permeability. High } \\
\text { sorptive capacity. }\end{array}$ \\
\hline \multirow[t]{2}{*}{ (See table $1, p .5$ ) } & & 4 & $\begin{array}{l}\text { Alluvium and slope deposits; normally highly permeable material such as } \\
\text { sand and gravel, and fragments of bedrock. Low to moderate sorptive capacity. }\end{array}$ \\
\hline & & 2 & $\begin{array}{l}\text { Glacially derived deposits; low to moderate permeability. Moderate to } \\
\text { high sorptive capacity. }\end{array}$ \\
\hline \multirow[t]{4}{*}{$\begin{array}{l}\text { Slope of land } \\
\text { surface }\end{array}$} & \multirow[t]{4}{*}{$S$} & 20 & Prevailing slope greater that 25 percent. \\
\hline & & 10 & Pervailing slope $15-25$ percent. \\
\hline & & 2 & Prevailing slope $5-15$ percent. \\
\hline & & 0 & Prevailing slope $0-5$ percent. \\
\hline \multirow{4}{*}{$\begin{array}{l}\text { Thickness of sedimen- } \\
\text { tary deposits over- } \\
\text { lying bedrock }\end{array}$} & \multirow[t]{4}{*}{ T } & 20 & Less than $15 \mathrm{ft}(4.5 \mathrm{~m})$. \\
\hline & & 15 & $15-25 \mathrm{ft}(4.5-7.5 \mathrm{~m})$ \\
\hline & & 1 & $25-50 \mathrm{ft}(7.5-15 \mathrm{~m})$ \\
\hline & & 0 & More than $50 \mathrm{ft}(15 \mathrm{~m})$. \\
\hline
\end{tabular}

TO OBTAIN POLLUTION SUSCEPTIBILITY RATING: For each applicable geohydrologic characteristic, determine the field condition which is most appropriate and record the rating points for each. Then total the rating points of all pertinent field conditions and select the map unit in figure 28 which represents this total.

\section{An Evaluation of the Hillside Area Environment}

A numerical rating system can be used to evaluate the relative susceptibility of the hydrologic environment to pollution, as has been demonstrated by LeGrand (1964). Once the principal geohydrologic characteristics that determine pollution susceptibility have been identified and mapped for a given area, a rating table can be devised that integrates these factors into a total response to liquid waste disposal. Thus, a pollution susceptibility map may be prepared which approximates the land's capacity to absorb septic-tank discharge without endangering the water resources.

A pollution-susceptibility map for the Hillside area, figure 28 , is based on a numerical rating table (table 3 ) and two basic-data maps which delineate the principal geohydrologic characteristics (figs. 29 and 30 ).

Table 3 numerically rates the importance of each field condition for its potential of increasing the possibility of water-resource pollution from septic tanks. A rating of 20 points indicates a geohydrologic condition with the greatest potential to cause pollution, and a point rating of 0 indicates a condition with the least potential to cause pollution. The interrelation of rating points between these extremes is not linear; that is, a rating of 4 does not mean a given condition has the potential to cause an area to be twice as susceptible to pollution as a rating of 2 .
Figure 29 shows lakes and streams, areas of waterlogged land, seepages, and areas where ground water is near the surface. These features were defined in the section on land drainage problems (see fig. 14). Relative permeability of surficial earth materials is also shown in figure 29 and was derived from the surficialgeologic map and accompanying table (fig. 5 ; table 1 ).

Figure 30 is a land-slope map (Schmoll and Dobrovolny, 1972) that also includes a generalized representation of the thickness of unconsolidated sediments overlying bedrock. Because local detail of land slope cannot be shown, specific sites may be locally different than shown on this map. Similarly, the thickness of sediments may be more irregular than shown in figure 30, and test borings to $25 \mathrm{ft}(7.5 \mathrm{~m})$ in depth may be necessary to determine the thickness of unconsolidated sediments in many localities east of Hillside Drive.

The pollution-susceptibility map was constructed by superimposing the two basic-data maps. Numerical ratings were then obtained (table 3 ) and added to arrive at a total value for each differing segment of Hillside land. Finally, each locality was classified as belonging to one of four susceptibility units (see explanation, fig. 28) depending upon the magnitude of the sum of the rating points. 


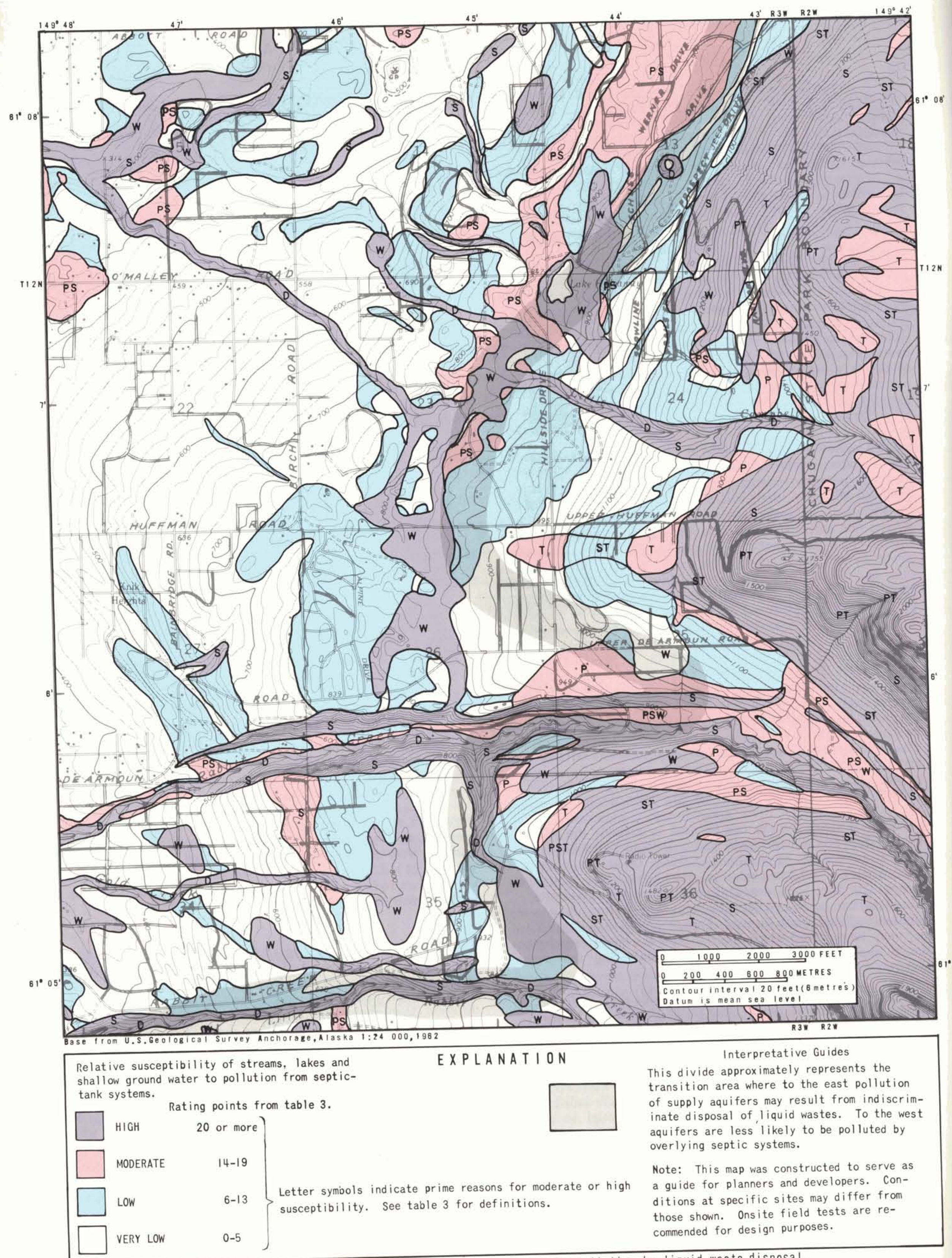

Figure 28 - Relative susceptibility of water resources to pollution by liquid waste disposal. 


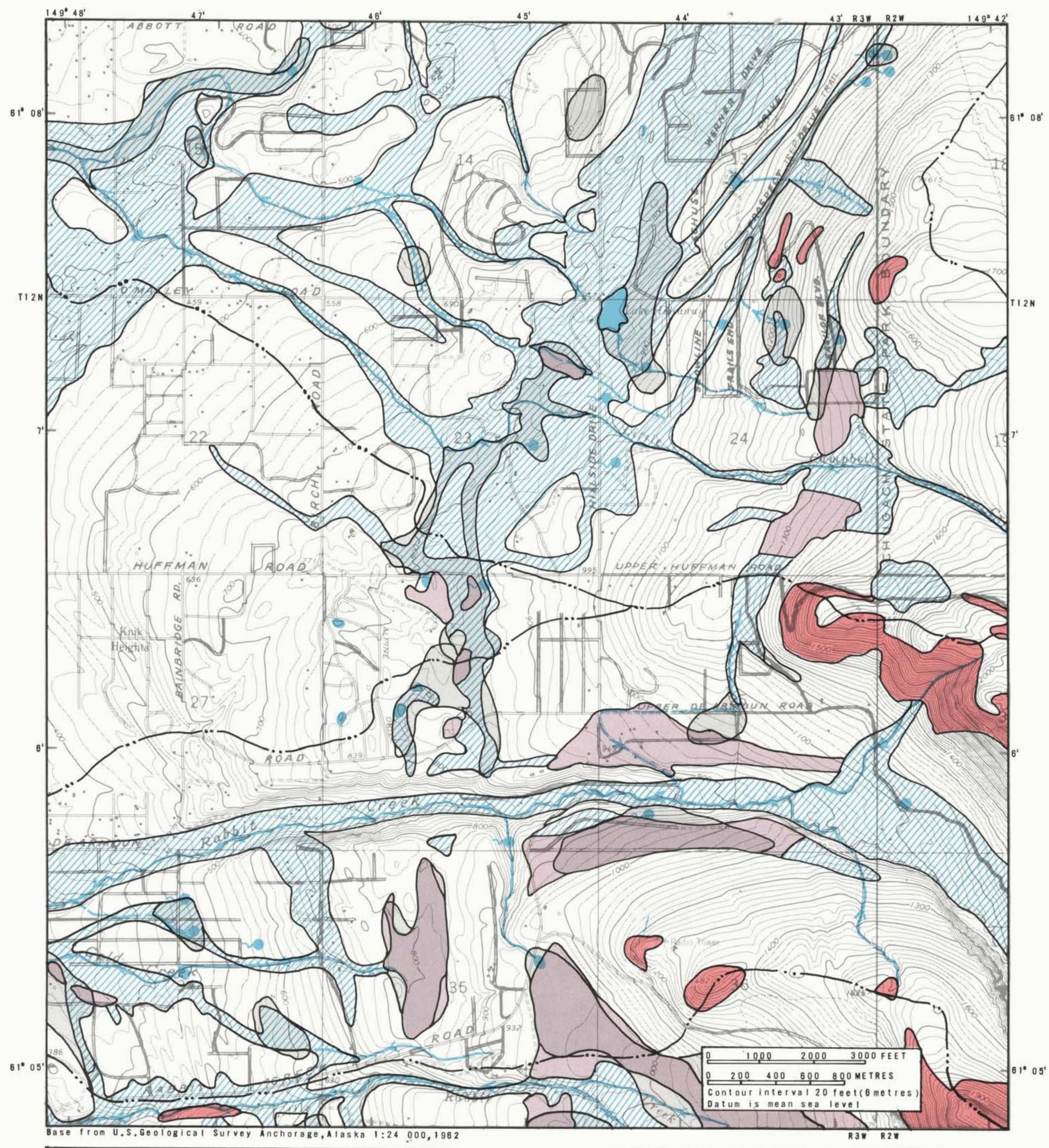

Surface-water features and near-surface ground water EXPLANATION Relative permeability of surficial soils (see table 1)
Lake or pond
Spring
Waterlogged land or
ground water within
$15 \mathrm{ft}$ ( $4.5 \mathrm{~m}$ ) of the
surface

Figure 29.-- Distribution of surface water, near-surface ground water, and relative permeability of surficial soils. 


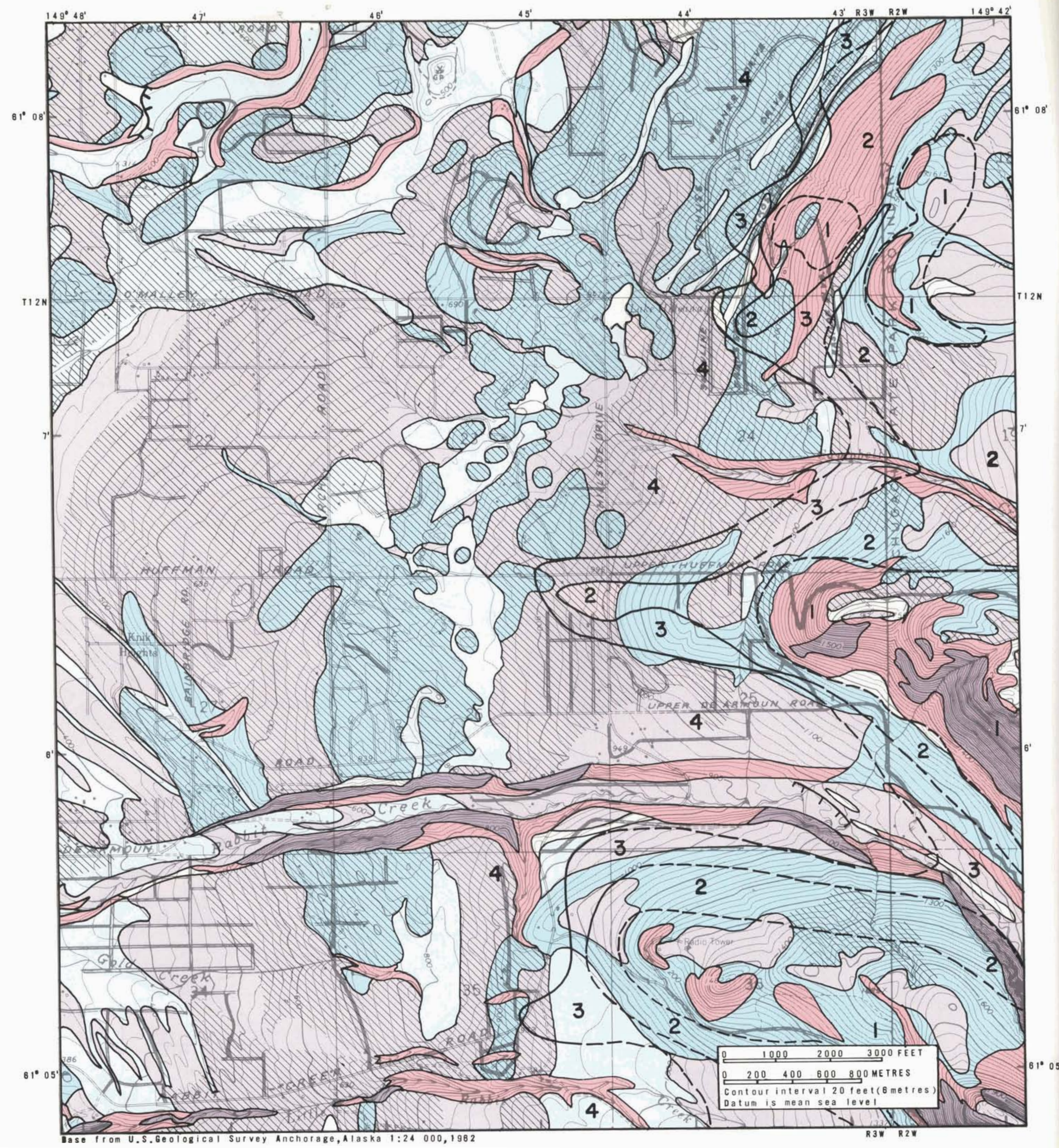

Figure 30.-- Generảlized landslope and sediment thickness near mountain front.

(Landslope map by Schmoll and Dobrovolny, 1972). 
EXPLANATION FOR FIGURE 30

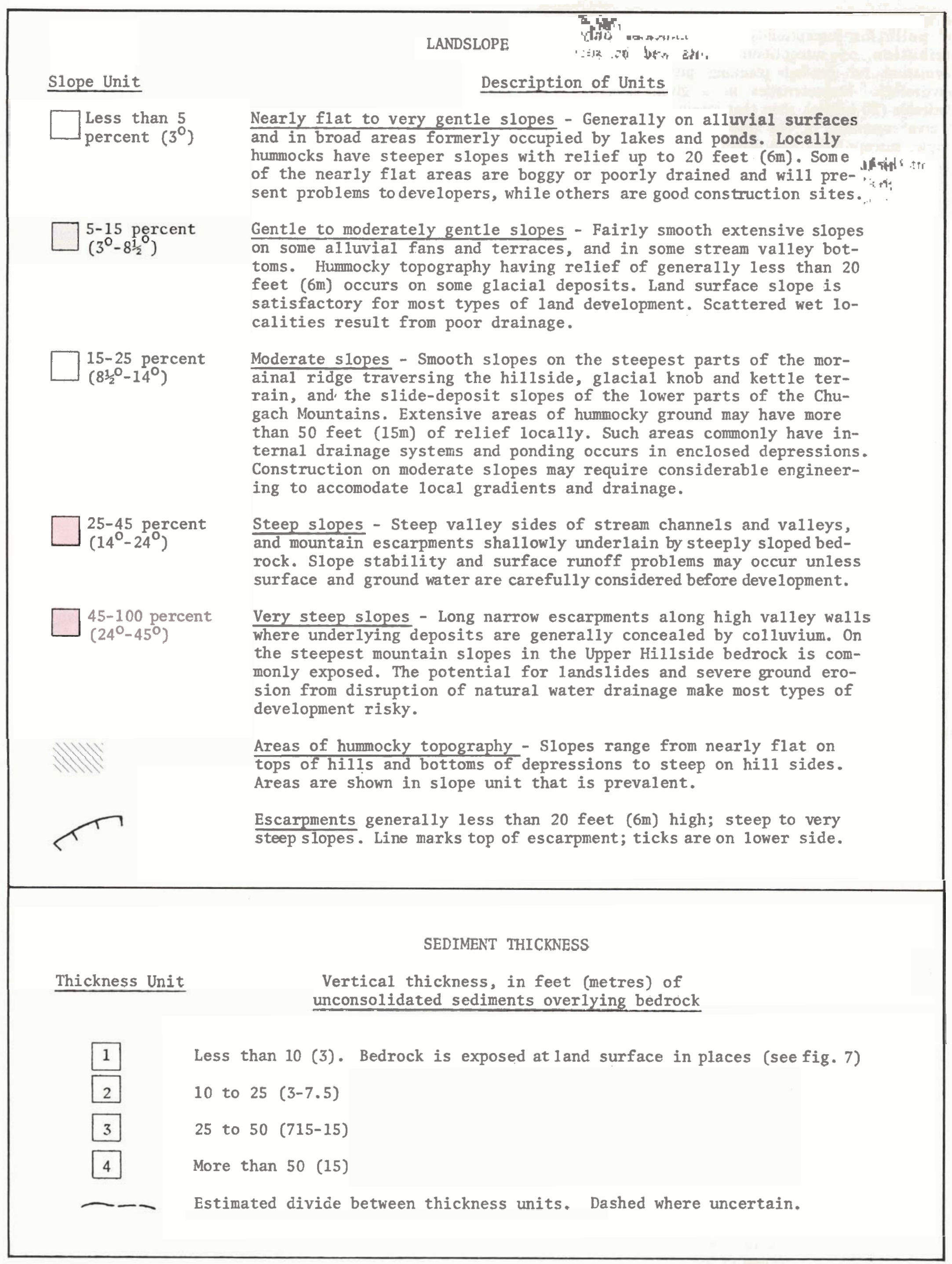


The pollution-susceptibility map indicates only the areal distribution of susceptibility units and as such provides information for general planning purposes. If one of the geohydrologic characteristics in a given locality was most undesirable ( 20 points), then that locality was classified as a high risk area regardless of the rating of other characteristics. For example, susceptibility was classified as high in localities where sediment thickness is less than $10 \mathrm{ft}(3 \mathrm{~m})$, even though depth to water is great, the land slope is slight, and the sediment permeability is moderate. Although figure 28 can be used to indicate the relative pollution susceptibility between differing localities, it may not represent local conditions at specific sites.

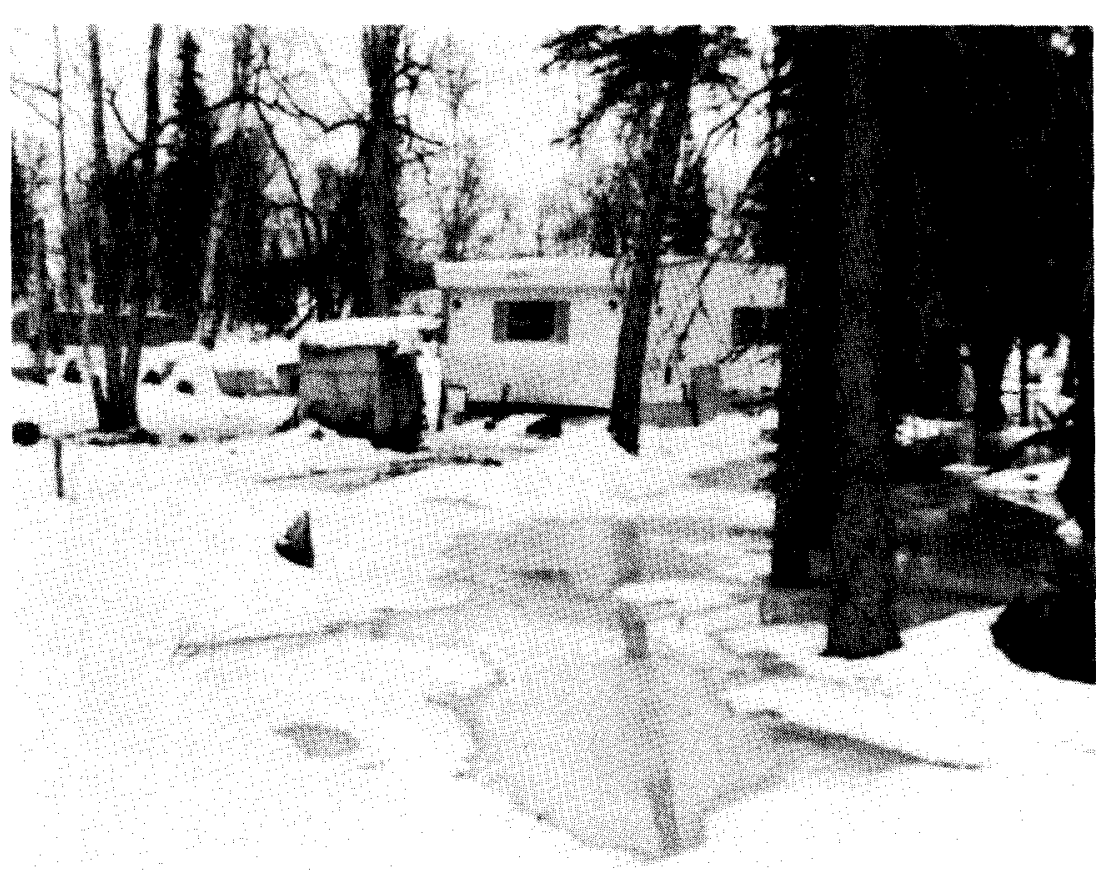

Figure 31.-- Ponded sewage from overflowing seepage pit.

overflows of septic effluent may contaminate nearby wells, lakes, and streams.

Photograph courtesy of The Greater Anchorage Area Borough

The most immediate pollution problem is the possibility of waste-water seepage directly into nearby wells. Seepage pits can become plugged and eventually overflow (fig. 31 ) because of low permeability of the surrounding earth materials or because of biologic failure. Soil stratification and steep slopes can cause seepage-pit effluent to move horizontally in the subsurface to wells or to rise to the surface and flow overland to well sites, lakes, and streams. In these instances, contaminants may enter a well if the casing is not watertight or if surface drainage easily moves down the outside of the casing to the aquifer. The mounding of earth and the emplacement of a concrete pad around the casing above the general ground level will cause drainage away from the well and help prevent surface-water leakage to the aquifer. In other areas where ground water occurs near the surface, overflowing effluent may flow overland from malfunctioning seepage pits and infiltrate to the water table and move downgradient to surround wells or to discharge into lakes and streams.

Ground water in the Hillside area probably has not been polluted by the current density of domestic sewage systems. However, the probability of future aquifer pollution because of a much greater density of onsite waste-disposal systems is relatively high in the upper Hillside area, or generally east of the dashed band in figure 28 . This band follows closely the map contact between units 2 and 3 in figure 9 , or where the depth to water below the land surface is less than $50 \mathrm{ft}(15 \mathrm{~m})$ to the east of this contact. West of this band the probability is generally much lower that aquifers will be polluted by septic-tank discharge.

\section{CONCLUSIONS}

Potable water supplies, surficial drainage, and onsite waste disposal may be limiting factors in single-family housing in some Hillside areas. Dense development may result in the local depletion of aquifers or increased surface drainage problems, or lead to groundand surface-water pollution unless community water and sewage facilities are substituted for individual systems in the susceptible areas. The major water-resource considerations facing planners and developers are briefly summarized below.

Ground-water sources generally are available, but yields to many wells are less than $5 \mathrm{gal} / \mathrm{min}(0.3 \mathrm{l} / \mathrm{s})$. Where wells produce from bedrock aquifers in the eastern Hillside area, yields commonly are less than $3 \mathrm{gal} / \mathrm{min}(0.2 \mathrm{l} / \mathrm{s})$ and rarely more than $10 \mathrm{gal} / \mathrm{min}(0.6$ $1 / \mathrm{s})$. Development of public-supply wells that yield more than 0.1 $\mathrm{Mgal} / \mathrm{d}(70 \mathrm{gal} / \mathrm{min}$ or $4.4 \mathrm{l} / \mathrm{s})$ is possible only in a few localities (fig. 10). A total sustained yield of at least $2 \mathrm{Mgal} / \mathrm{d}\left(0.08 \mathrm{~m}^{3} / \mathrm{s}\right)$, and possibly as much as $4 \mathrm{Mgal} / \mathrm{d}\left(0.17 \mathrm{~m}^{3} / \mathrm{s}\right)$ can be obtained from small-yield domestic wells tapping sedimentary aquifers underlying the study area. A small number of public-supply wells properly spaced in the best producing aquifers might provide a significant part of the total areal production. Surface-water reservoirs or diversions from the streams crossing the area do not appear to be practical sources of water.

Surface-water runoff and waste-water disposal is perhaps more of a problem than providing an adequate supply of potable water. In numerous locations, steep slopes, swamps and shallow ground water, and low permeability of surficial earth materials could make the use of septic-tank systems hazardous to public health, and also cause critical drainage conditions. Septic-tank effluent must percolate into and be cleansed by surficial sediments otherwise, streams, lakes, aquifers, and even the land surface can become contaminated. At this time, the total load of pollutants that the sediments can absorb is not determinable, but onsite waste disposal has the potential to cause pollution in much of the Hillside area (fig. 28). Particularly where the land is not conducive to cleansing liquid-waste discharge within critical distances, the density of development will determine the degree of change in water quality locally and downslope from development.

Preservation of natural stream channels and the use of runoff design criteria in the construction of roads, ditches, and small drainage channels during development will reduce problems associated with surface-water drainage and winter icings Fortunately, the two major streams, Rabbit and Little Rabbit Creeks, flow through incised valley channels and pose a flood threat to only those residents who live within the narrow flood plain. However, a number of closed depressions are subject to ponding of water during unusually heavy runoff periods.

Use of water-resources data by community planners, developers and property owners could assist them in assessing potential water supply, drainage, and pollution problems, particularly in areas such as the Hillside where public water and sewers are not now planned. 
Barnwell, W.W., George, R.S., Dearborn, L.L., Weeks, J.B., and Zenone, Chester, 1972 , Water for Anchorage--An atlas of the water resources of the Anchorage area, Alaska: U.S. Geol. Survey open-file report (pub. by city of Anchorage and Greater Anchorage Area Borough), 77 p.

Bender, W.H., 1961, Soils suitable for septic-tank filter fields--A soil map can help you: U.S. Dept. Agriculture, Soil Conservation Service, Agriculture Inf. Bull. 243, 12 p.

Bouma, J., Ziebell, W.A., Walker, W.G., Olcott, P.G., McCoy, E., and Hole, F.D., 1972, Soil absorption of septic tank effluent--A field study of some major soils in Wisconsin: Wisconsin Univ. Extension, Geol. and Nat. History Survey, Soil Survey Div., Inf. Circ. 20, 235 p.

Clark, S.H.B., 1973 The McHugh Complex of south-central Alaska: U.S. Geol. Survey Bull. 1372-D, p. D1-D10.

Clark, S.H.B., and Bartsch, S.B., 1971, Reconnaissance geologic map and geochemical analyses of stream-sediment and rock samples of the Anchorage B-7 quadrangle, Alaska: U.S. Geol. Survey open-file report, 70 p.

Cederstrom, D.J., Trainer, F.W., and Waller, R.M., 1964, Geology and ground-water resources of the Anchorage area, Alaska: U.S. Geol. Survey Water-Supply Paper $1773,108 \mathrm{p}$.

Crosby, J.W., III, Johnstone, D.L., Drake, C.H., and Fenton, R.L., 1968, Migration of pollutants in a glacial outwash environment: Water Resources Research, v. 4, no. 5 , p. 1095-1113.

Environmental Protection Agency, 1972, Water quality criteria 1972--A report of the Comm. on Water Quality Criteria, Environmental Studies Board, Natl. Acad. of Sci., Natl. Acad. of Eng.: Washington, U.S. Govt. Printing Office, 594 p. [1973]

Federal Water Pollution Control Administration, 1968, Water quality criteria--A report of the Natl. Tech. Advisory Comm: Washington, U.S. Govt. Printing Office, 234 p.

Ferguson, Hayden, Brown, P.L., and Dickey, D.D., 1964, Water movement and loss under frozen soil conditions: Soil Sci. Soc. America Proc., v. 28, p. 700-703.

Franks, A.L., 1972, Geology for individual sewage disposal systems: California Geology, v. 25 , no. 9 , p. $195-203$.

Greater Anchorage Area Borough, Comprehensive Planning and Technical Services Division, 1972, People in Anchorage: Greater Anchorage Area Borough, 109 p.

Greater Anchorage Area Borough, Planning Department, 1972, Population Projections . 1970-1980: Greater Anchorage Area Borough, 15 p.

Guy, H.P., 1970, Sediment problems in urban areas: U.S. Geol. Survey Circ. 601-E, p. E1-E8.

Harlan, R.L., 1972, Ground conditioning and the groundwater response to surface freezing, in Proc. of Banff Symposia on the Role of Snow and Ice Hydrology, Banff, Canada, 1972: Internat. Assoc. of Sci. Hydrology Pub. 107, v. 1, p. 326-341.

Hines, W.G., 1973, Evaluating pollution potential of land-based waste disposal, Santa Clara County, California: U.S. Geol. Survey Water-Resources Inv. 31-73, 17 p. (pamphlet to accompany map).

Karlstrom, T.N.V., 1964, Quaternary geology of the Kenai Lowland and glacial history of the Cook Inlet region, Alaska: U.S. Geol. Survey Prof. Paper 443, 69 p.

LeGrand, H.E 1964, System for evaluation of contamination potential of some waste disposal sites: Am. Water Works Assoc. Jour., v. 56, no. 8, p. 959-974. 
Leopold, L.B., Clarke, F.E., Hanshaw, B.B., and Balsley, J.R., 1971, A procedure for evaluating environmental impact: U.S. Geol. Survey Cir. 645, 13 p.

McGaughey, P.H., and Krone, R.B., 1967, Soil mantle as a wastewater treatment system: California Univ. Sanitary Eng. Research Lab., SERL Rept. 67-11, 201 p.

McHarg, I.L., 1969, Design with nature: Garden City, N.Y., Natural History Press (for Am. Mus. Nat. History), 198 p.

Peck, E.L., 1974, Effect of snow cover on upward movement of soil moisture: Am. Soc. Civil Eng. Proc., Jour. Irrigation and Drainage Div., v. 100, p. 405-412.

Rickert, D.A., Schneider, W.J., and Spieker, A.M., 1973, A procedure for assessing water resources for urban planning: Am. Water Resources Assoc., Water Resources Bull., v. 9 , no. 4,25 p.

Schmoll, H.R., and Dobrovolny, Ernest, 1972, Generalized geologic map of Anchorage and vicinity, Alaska: U.S. Geol. Survey Misc. Geol. Inv. Map I-787-A.

1972, Slope map of Anchorage and vicinity, Alaska: U.S. Geol. Survey Misc. Geol Inv. Map I-787-B.

Schneider, W.J., 1970, Hydrologic implications of solid-waste disposal: U.S. Geol. Survey Circ. 601-F, p. F1-F10 [1972, 1973 ].

Schneider, W.J., Rickert, D.A., and Spieker, A.M., 1973, Role of water in urban planning and management: U.S. Geol. Survey Circ. 601-H, p. H1-H10.

Sommers, D.A., and Marcher, M.V., 1965, Water resources appraisal of the Anchorage area Alaska - Water conservation through conjunctive use: U.S. Geol. Survey open-file report, $34 \mathrm{p}$.

Spieker, A.M., 1970, Water in urban planning, Salt Creek basin, Illinois--Water management as related to alternative land-use practices: U.S. Geol. Survey Water-Supply Paper $2002,147 \mathrm{p}$.

State of Alaska, 1963, Greater Anchorage water pollution survey, 1961 (July 17 through November 30), Alaska: Dept. of Health and Welfare, Hydrol. Data report 20,12 p.

Taylor, S.A., and Cary, J.W., 1965, Soil-water movement in vapour and liquid phases, in Eckardt, F.E., ed., Methodology of plant eco-physiology: Paris, France, Proc. of the Montpellier Symposium UNESCO, p. 159-165.

Trainer, F.W., and Waller, R.M., 1965, Subsurface stratigraphy of glacial drift at Anchorage, Alaska: U.S. Geol. Survey Prof. Paper 525-D, p. D167-D174.

U.S. Army Corps of Engineers, 1973, Flood-plain information, Rabbit Creek, Anchorage Alaska: U.S. Army Corps of Eng., Alaska Dist., 27 p., 29 pl.

U.S. Public Health Service, 1962, Public Health Service drinking water standards: U.S. Public Health Service Pub. 956, 61 p.

Water Well Journal, 1970, The authoritative primer; Ground water pollution: Water Well Jour., v. 24 , no. 7,93 p.

Zenone, Chester, 1973 , Geology of water resources of the Girdwood-Alyeska area, Alaska: U.S. Geol. Survey open-file report (pub. by Greater Anchorage Area Borough), 24 p.

Zenone, Chester, Schmoll, H.R., and Dobrovolny, Ernest, 1974, Geology and ground water for land-use planning in the Eagle River-Chugiak area Alaska: U.S. Geol. Survey open-file report 74-57 (pub. by Greater Anchorage Area Borough), 25 p. 
APPENDIXA-1 Drillers' logs of selected wells in the Hillside Area, Anchorage, Alaska

\begin{tabular}{|c|c|c|c|}
\hline $\begin{array}{l}\text { Well no: } \\
\text { Owner: } \\
\text { Driller: }\end{array}$ & $\begin{array}{l}\text { SB012 } 00313 \text { DDAD; map no. } 1 \\
\text { Carl Luchsinger } \\
\text { C. P. Foss }\end{array}$ & $\begin{array}{l}\text { Thickness } \\
\text { (feet) }\end{array}$ & $\begin{array}{l}\text { Depth } \\
\text { (feet) }\end{array}$ \\
\hline $\begin{array}{l}\text { Clay, san } \\
\text { Bedrock, } \\
\text { Bedrock, }\end{array}$ & $\begin{array}{l}\text { Id, and gravel, brown, medium hard } \\
\text { grey, soft } \ldots \ldots \\
\text { grey, hard } \ldots \ldots\end{array}$ & $\begin{array}{l}40 \\
10 \\
75\end{array}$ & $\begin{array}{r}40 \\
50 \\
125\end{array}$ \\
\hline
\end{tabular}

\section{Well no: SB 01200313 DDDC; map no.}

Owner:
Driller: Sllen Woodward
Swafford Drilling co.

\begin{tabular}{|c|c|c|}
\hline $\begin{array}{l}\text { No record } \\
\text { Clay and grave1, hard, greenish. } \\
\text { Sand and gravel, greenish. . . } \\
\text { Sand, silty, medium, brown } \\
\text { Sand and gravel, hard, brown :. } \\
\text { Sand and grave1, clean; water. }\end{array}$ & $\begin{array}{r}96 \\
9 \\
30 \\
57 \\
4 \\
2\end{array}$ & $\begin{array}{r}96 \\
105 \\
135 \\
192 \\
196 \\
198\end{array}$ \\
\hline
\end{tabular}

Open-end finish

Wel1 no: SB 01200313 BBBC; map no. 8

Owner:
Driller: Dames Tanaka
Dotten Drilling co.

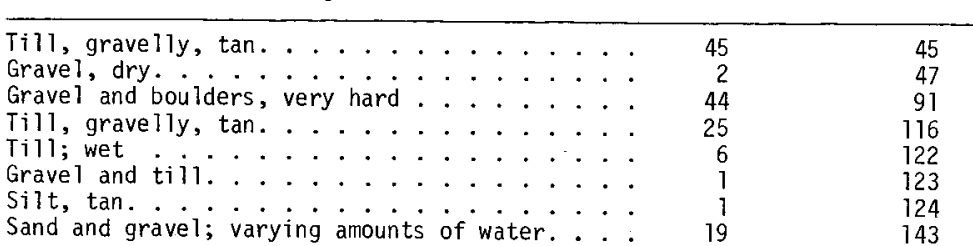

open-end finish

We11 no: SB 01200313 ABDD; map no. 20

Owner: Carl Luchsinger
Driller: Foss Drilling

\begin{tabular}{lll}
\hline Clay, sand, gravel, brown, hard. . . . . . & \\
Bedrock, grey, medi um hard $\ldots \ldots$ & 23 & 23 \\
Bedrock, li ght grey, hard $\ldots \ldots \ldots \ldots$ & 37 & 60 \\
Bedrock, red, medium hard $\ldots \ldots \ldots \ldots \ldots$ & 20 & 80 \\
\end{tabular}

open-end finish

Well no: SB 01200313 DCBB; map no. 2

Driller: Charles Houtchen

Sand and gravel, brown, medium hard

Sand and gravel, brown, hard. .

Bedrock, grey, medium hard.

Bedrock, green, medium hard; water.

Bedrock, brown streaks, medium hard

Bedrock, grey, medium hard

Bedrock, brown streaks, medium hard, water.

Bedrock, green, medium hard

open-end finish

Wel1 no: SB $01200314 \mathrm{DADB}$; map no. 5

Owner:
Driller: Clemenson Drilling co.

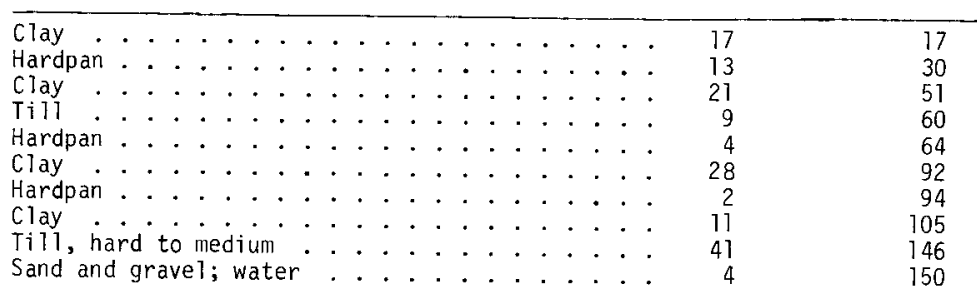

Open-end finish
Wel1 no: SB 01200314 JCBC; map no. 11

Oriller: Clemenson Drilling co.

Gravel. Glayey

Clay, brown, very $i_{i t t l e}$ gravei; water seepage

Clay, sandy, grave

Clay, gravelly; water seepa.

Silt, grey; water-bearing sand and gravei at jisi: Sand, silty, brown, very little gravel . . . Gravel and sand, a little silt at $128^{\prime}$, clayey
at bottom; water-bearing, screened $120^{\prime}-130^{\prime}$

and tested at $50 \mathrm{gmm}$, static level 601

Clay, grey, very 1 ittle grave 1; no water.

Clay, gravelly, grey; water seepage

Clay, gravelly, to clayey gravel; no water.

Gravel, sandy, and gravelly sand; water-bearing
Pumped 168 gpm, 25 hours with 1071 drawdown

Screen 174'-179', 200-s lot

Well no: SB 01200315 DDAA; map no. 1

Owner: LeRoy Allinger
Driller: Swafford Drilling Co.

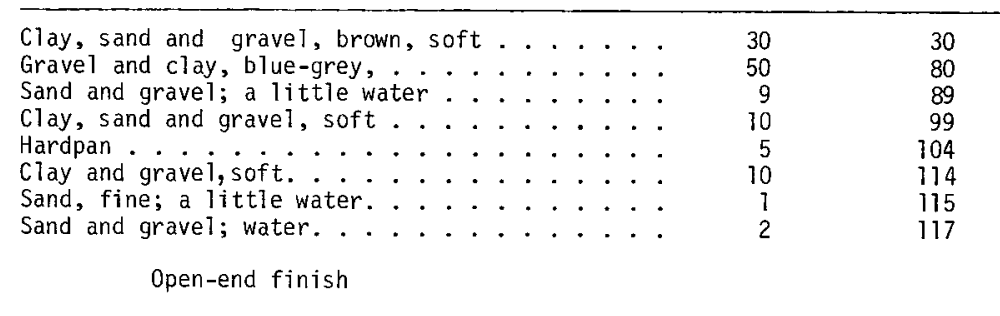

Wel1 no: SB 01200315 ADCD; map no. 5

Owner:
Driller: Sterling

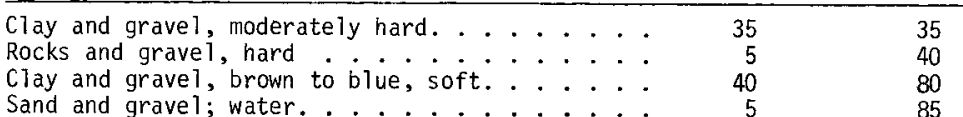

Open-end finish

Wel1 no: SB $01200315 \mathrm{BBCD}$; map no. 6

$\begin{array}{ll}\text { Owner: } & \text { C. S. Sullivan } \\ \text { Driller: } & \text { A \& L Drilling Co. }\end{array}$

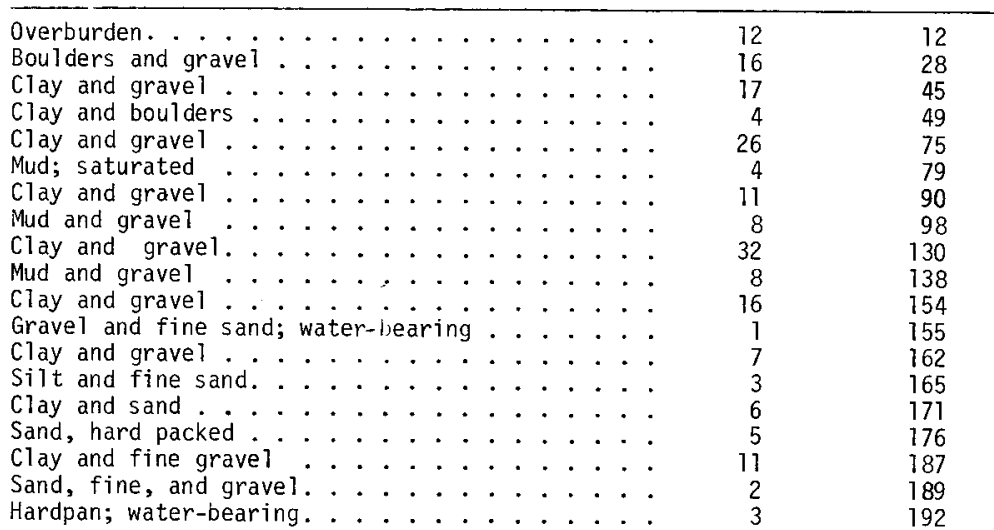

Open-end finish

We11 no: SB 01200315 CCAB; map no. 25

Owner: James M. Ryan

Clay, brown, and rock and sand. .

Clay, yellow, and sand

clay, yellow and

Grapan, sandy, gravelly, extremely har

Sand, gravel and clay in alternating layers.

Hardoan, sandy, graveliy; static water level

in January 1955 was $131 \mathrm{ft}, 5 \mathrm{gpm}$ with 15.
.

Clay, grey, and sand, si it and $1 / 4$ i gravel,
layered; s tatic water level in March 1955

Sand and gravei, grey, tili streaks; wet.

water-bearing at bottum of strata.

Open-end finish

\begin{tabular}{|c|c|}
\hline $\begin{array}{l}\text { Thicknesss } \\
\text { (feet) }\end{array}$ & $\begin{array}{c}\text { Depth } \\
\text { (feet) }\end{array}$ \\
\hline 20 & 20 \\
\hline 23 & $\begin{array}{l}43 \\
46\end{array}$ \\
\hline $\begin{array}{r}3 \\
38\end{array}$ & $\begin{array}{l}46 \\
84\end{array}$ \\
\hline $\begin{array}{l}38 \\
23\end{array}$ & $\begin{array}{l}64 \\
107\end{array}$ \\
\hline 7 & 174 \\
\hline 2 & 116 \\
\hline 6 & 122 \\
\hline 8.5 & 130.5 \\
\hline 12.5 & 143 \\
\hline 21.5 & 171.5 \\
\hline 3.5 & 174 \\
\hline 5 & 179 \\
\hline
\end{tabular}

tons

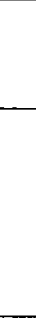

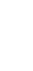




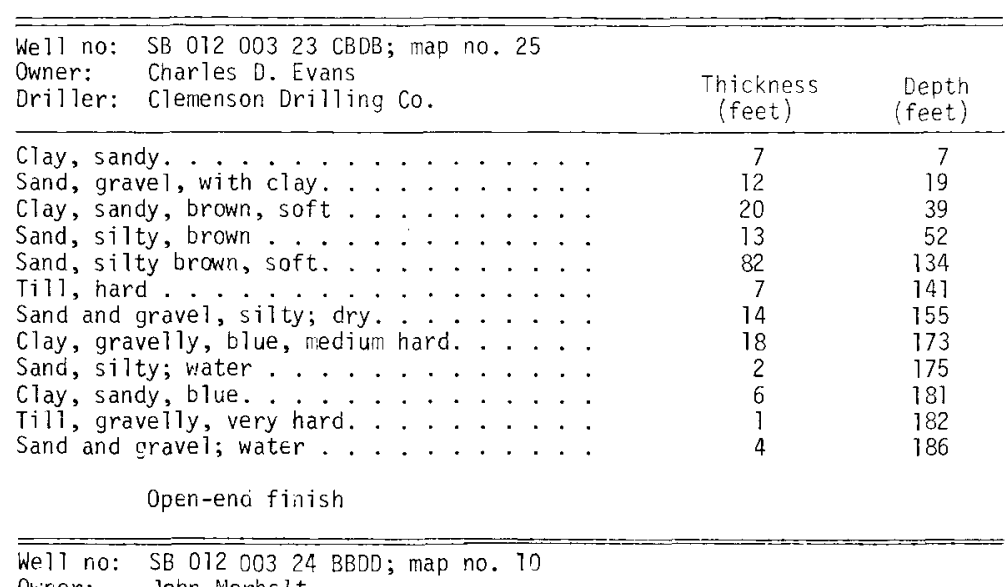

Owher: John Merholt
Driler: Cotten Dritling

Till, gravelly, tan; rock at 43 feet;

weak water towards bot

Sill, sandy, tan; dry.

Sand and gravei, medium to coarse tan

Open-end finish

Well no: SB 01200324 BBDD; map no. 12

Owner:
Oriller: Dotten Drilling Co.

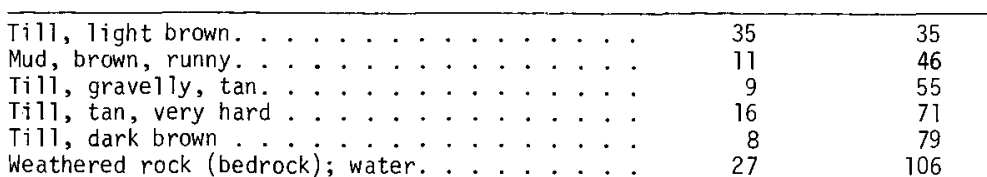

open-end finis

Wel1 no: SB 01200324 ACBA; map no. 16

Owner:
Driller: Fos

Clay, sand, and gravel, grey, medium hard.

clay, sand, and grave 1, grey, medium hard. :

Slat-type perforated finish

We71 no: SB 01200324 AABB; map no: 18

$\begin{array}{ll}\text { Owner: } & \text { Keith Giddings } \\ \text { Driller: Swafford Drilling Co. }\end{array}$

Clay, sand, and gravel, brown, medium hard.

Bedrock, fractured, brown, soft; some water.

Bedrock, green, medium hard; some water.

$$
\text { Open-end finish }
$$

We11 no: SB 01200324 CDBD; map no. 20

\begin{tabular}{l} 
Owner: \\
Driller: Sob Prescott \\
\hline
\end{tabular}

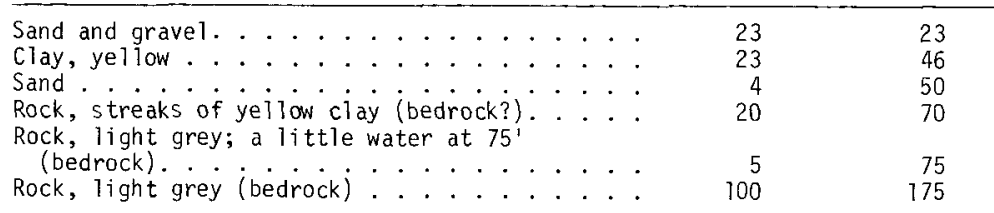

We11 no: SB 01200325 CBBD; map no. 2

$\begin{array}{ll}\text { Owner: } & \text { Eugene Januiewiz } \\ \text { Driller: } & \text { Swafford Drilling co. }\end{array}$

Clay and gravel, brown, medium hard and hard

Clay and gravel, brown, medium hard.

Clay and grave 1, blue, medi um hard; water

Sand and gravel; water $(3-1 / 2$ gpm)
Clay and grave 1, brown, some silty sand

Clay and graver,

medium hard.
Sand, fine; water.

Open-end finish
Wel1 no: SB 01200325 CCAA; map no. 5

Dritler: Swafford Dritling co.

Sand and gravel, brown

Sand and gravel, hard; water

open-end finish

Wel1 no: SB 01200325 ABDD; map no. 8

$\begin{array}{ll}\text { Owner: } & \text { H. Roy Fisk } \\ \text { Oriller: } & \text { A \& L Drilling Co. }\end{array}$

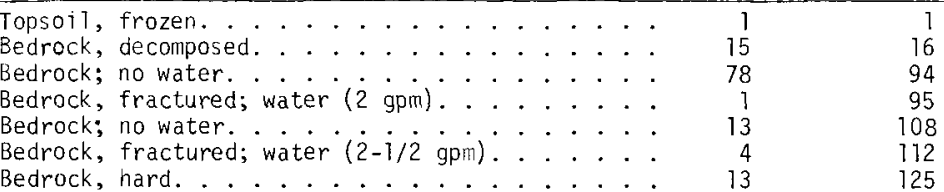

open-end finish below 42 feet

We11 no: SB 01200325 BDBD; map no. 23

Driller: Sonnmerville Well Drilling

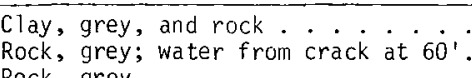

Rock, red; water from crack at $170^{\circ}$ Open-end finish

We11 no: SB 01200325 BBBD; map no. 24

Owner: James Fuerstenberg

$\begin{array}{lll}\text { Sand, gravel and boulders. . . . . . . . . . . } & 20 & 20 \\ \text { Bedrock. . . . } & 75 & 95\end{array}$

Open-end finish

Well no: SB 01200326 CBC8; map no.

$\begin{array}{ll}\text { Owner: } & \text { L. B. Martin } \\ \text { Driller: } & \text { Swafford Drilling Co. }\end{array}$

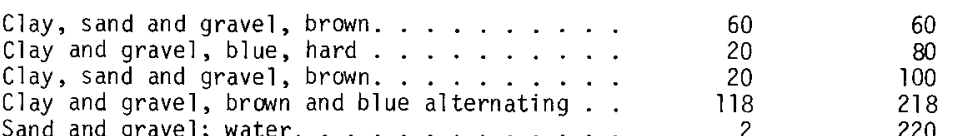

Open-end finish

Well no: SB 01200326 AAAA; map no. 5

$\begin{array}{ll}\text { Owner: } & \text { Stanford Spendlove } \\ \text { Driller: } & \text { Hyland Drilling Co. }\end{array}$

\begin{tabular}{llll}
\hline Ti11, yellow. & \\
Ti11, graveliy, yeilow; dry $\ldots \ldots \ldots$ & 10 & 10 \\
Cemented stone (bedrock?), grey; water. . . . . & 55 & 79
\end{tabular}

Open-end finish

We11 no: SB 01200326 DADA; map no. 7

Oiner: $\quad$ Frank Morgan

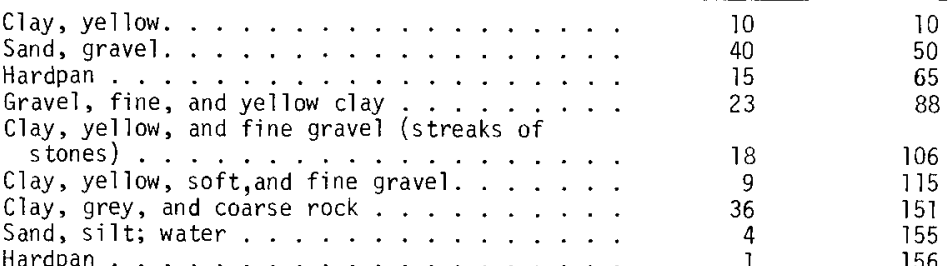

Open-end finish

Nel1 no: SB 01200326 DDDC; map no. 15

Owner: Don Grey, Jr.

Clay and gravel, brown, soft.
clay and gravel, grey, medium hard; water $\cdots$

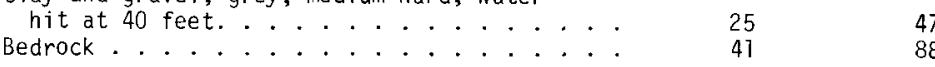

Open-end finish; perforated $39^{\prime}-40^{\prime}$

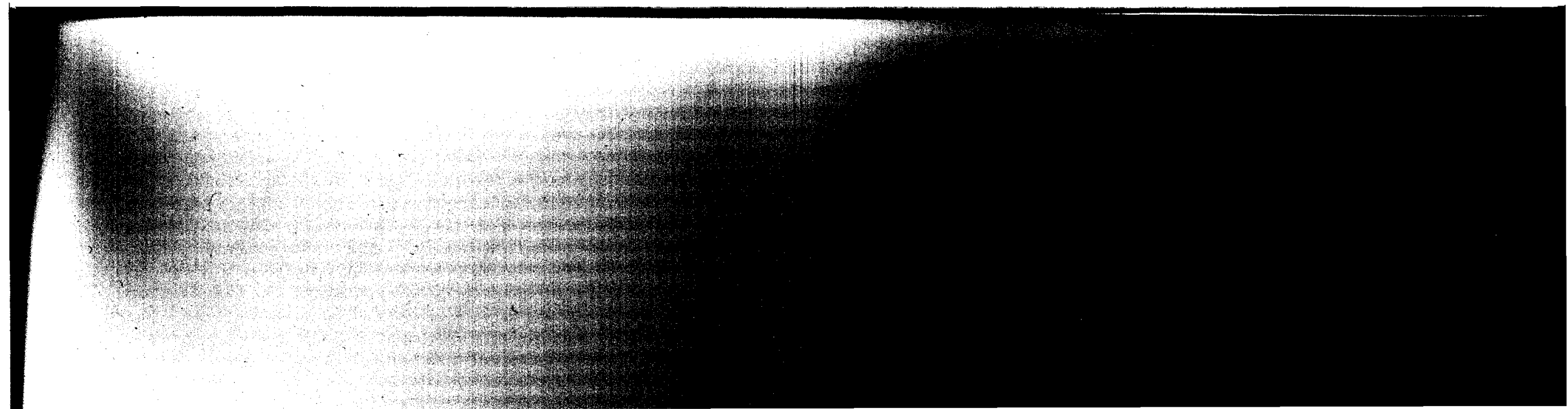




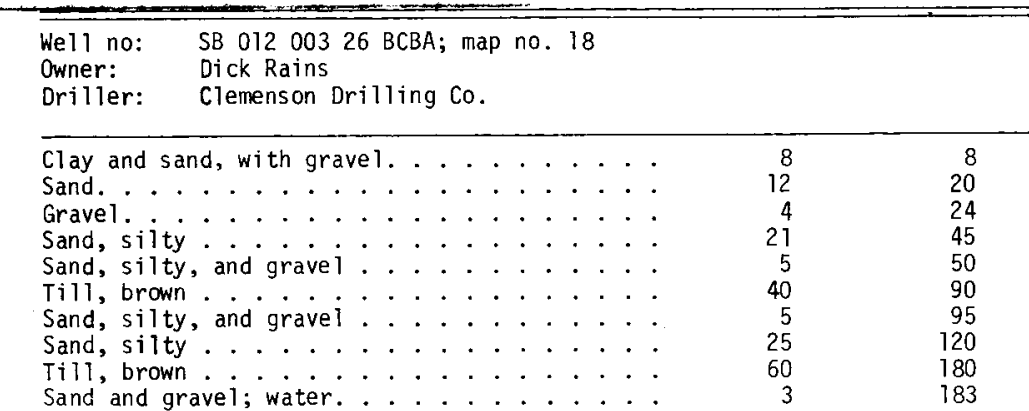

open-end finish

$\begin{array}{ll}\text { Well no: } & \text { SB } 01200327 \text { CADA; map no. } 3 \\ \text { Owner: } & \text { Marvin Miller }\end{array}$

$\begin{array}{ll}\text { Owner: } & \text { Marvin Miller } \\ \text { Driller: } & \text { Swafford Drilling co. }\end{array}$

\begin{tabular}{|c|c|c|}
\hline 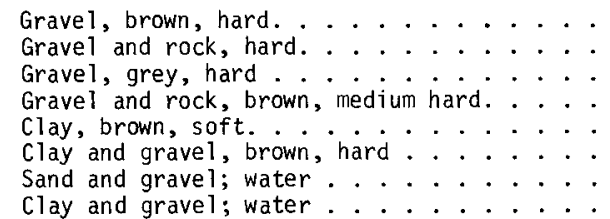 & $\begin{array}{r}70 \\
50 \\
9 \\
43 \\
17 \\
22 \\
2 \\
17\end{array}$ & $\begin{array}{r}70 \\
120 \\
129 \\
172 \\
189 \\
211 \\
213 \\
230\end{array}$ \\
\hline
\end{tabular}

Sand and grave1; water
clay and gravel; water

open-end finish

Well no: SB 01200327 CCDA; map no. 5

$\begin{array}{ll}\text { Owner: } & \text { G. Heaverly } \\ \text { Driller: } & \text { Clemenson Drilling co. }\end{array}$

\begin{tabular}{|c|c|c|}
\hline Till ............. & 11 & 11 \\
\hline $\begin{array}{l}\text { Gravel with boulders, silty, brown; } \\
\text { water seepage. . . . . . . }\end{array}$ & 43 & \\
\hline Till, blue, (hardpan) $\ldots \ldots$ & 9 & 63 \\
\hline Sand, silt, and gravel (tiil), soft & & \\
\hline $\begin{array}{l}\text { Till, sandy, silty, gravelly, wi th boulders, } \\
\text { brown. }\end{array}$ & 44 & \\
\hline Silt, sand and gravel; dry & 10 & 124 \\
\hline Sand and silt; water (dirty) & 4 & 128 \\
\hline $\mathrm{Ti} 11$, sandy, blue. . . . . & 14 & 142 \\
\hline Ti11, sandy, brown .... & 3 & 145 \\
\hline Grave 1, sandy, grey, hard. & 12 & 157 \\
\hline $\begin{array}{l}\text { Grave 1, sandy, blue, hard, with large } \\
\text { rocks. }\end{array}$ & & \\
\hline $\begin{array}{l}\text { Gravel, sandy, blue, hard, very dense. . } \\
\text { Sand, brown, and grave1; water.... }\end{array}$ & 6 & $\begin{array}{l}170 \\
170\end{array}$ \\
\hline & & \\
\hline
\end{tabular}

Well no: SB 01200327 ABCA; map no. 25

$\begin{array}{ll}\text { Owner: } & \text { Edward McCain } \\ \text { Driller: } & \text { Arctic Drilling }\end{array}$

\begin{tabular}{|c|c|c|}
\hline $\begin{array}{l}\text { Clay and gravel. } \\
\text { Gravel, sandy. } \\
\text { Till, brown; boulder from } 105 \text { to } 110 \text { ' } \\
\text { Hardpan, } \\
\text { Sand, silty; water } \\
\text { Gravel; water. }\end{array}$ & $\begin{array}{r}25 \\
10 \\
120 \\
60 \\
6 \\
1\end{array}$ & $\begin{array}{r}25 \\
35 \\
155 \\
215 \\
221 \\
222\end{array}$ \\
\hline
\end{tabular}

Sand, silty; water
Grave1; water.

Open-end finish

Well no: SB 01200327 BDCB; map no. 27

$\begin{array}{ll}\text { Owner: } & \text { Arthur Parker } \\ \text { Driller: } & \text { Clemenson Drilling Co. }\end{array}$

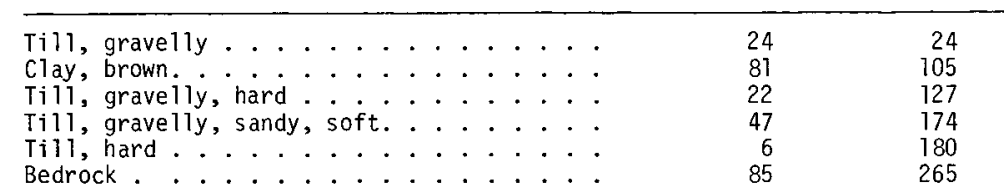

Open-end finish

Wel1 no: SB 01200334 CCDB; map no. 1

\begin{tabular}{ll} 
Owner: & Curtis Young \\
Driller: & Robert Cross \\
\hline
\end{tabular}

\begin{tabular}{|c|c|c|}
\hline $\begin{array}{l}\text { Record missing (dug wel1) } \\
\text { Sand, brown. } \\
\text { Hardpan } \\
\text { Gravel and sand, water } \\
\text { Clay and gravel } \\
\text { Hardpan. } \\
\text { Bedrock. }\end{array}$ & $\begin{array}{r}38 \\
2 \\
5 \\
5 \\
9 \\
47.5 \\
143.5\end{array}$ & $\begin{array}{c}38 \\
40 \\
45 \\
50 \\
59 \\
108.5 \\
275\end{array}$ \\
\hline
\end{tabular}

Bedrock.

Well no: SB 01200334 BBBB; map no. 2

$\begin{array}{ll}\text { Wwner: } & \text { Earl Morell } \\ \text { Driller: } & \text { Swafford Drilling co. }\end{array}$

Clay and gravel, brown and blue alternating;

a little water at 53 fe
Sand and gravel; water.

Open-end finish
We11 no: SB 01200334 BAAA; map no. 4

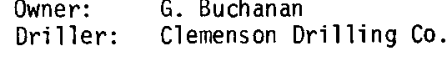

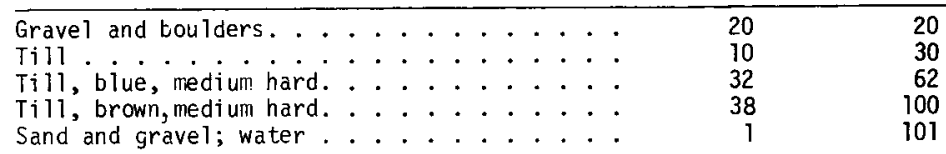

Open-end finish

Weli no: SB 07200334 AADC; map no. 27

$\begin{array}{ll}\text { Owner: } & \text { Robert Arwezon } \\ \text { Driller: } & \text { Hyland Drilling Co. }\end{array}$

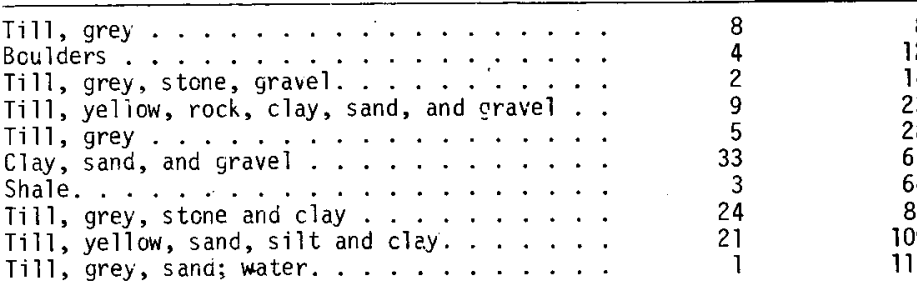

5 feet of 30 -slot screen finish

Wel1 no: SB 01200334 DDCA; riầ BC. 31

$\begin{array}{ll}\text { Owner: } & \text { Ralph L. Riggs } \\ \text { Driller: } & \text { Swafford Drilling co. }\end{array}$

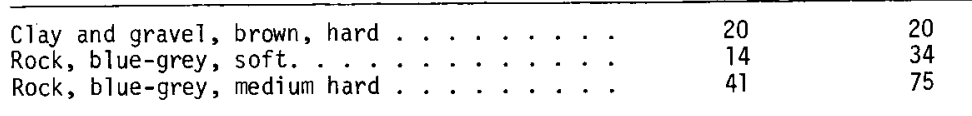

$\begin{array}{ll}\text { Wel1 no: } & \text { SB } 01200335 \text { CCDA; map no. } 1 \\ \text { Owner: } & \text { John Wi1ls } \\ \text { Driller: } & \text { Lloyd Wilson }\end{array}$

Rock and clay, compacted.

Rocks, large..

Hardpan.

clay and rock, reddishisticky

Gravel and sand, medium hard.

Open-end finish

We11 no: SB 01200335 BCCA; map no. 10

Driller: John Cox

Clay, yellow, and sand and stones

Rocks

Sand, fine gravei, and clay; a litite water at 40 feet.

Hardpan ... . . . . . . .

Clay, yel low, softer; a iittie water in sand

Hardpan ......

Sand, fine, very hard

Clay, yellow, soft.

Hardpan

Open-end finish

We11 no: SB 01200335 ACCA; map no. 15

Owner: Clark Degarmo

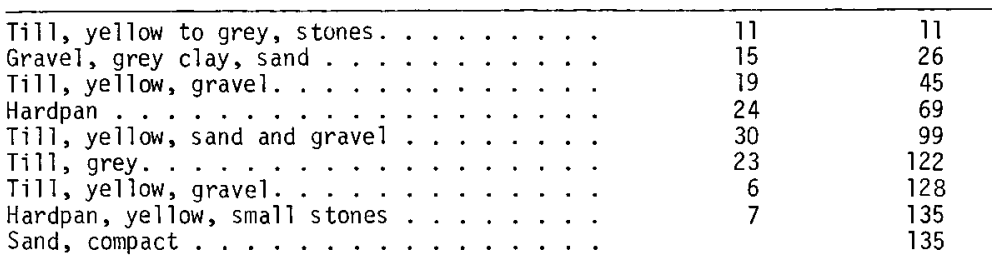

open-end finish

Well no: SB $01200335 \mathrm{AADD}$; map no. 18

$\begin{array}{ll}\text { Owner: } & \text { Ray Jones } \\ \text { Driller: } & \text { Swafford Drilling co. }\end{array}$

Till, grey, brow

Rock, grey.
Rock, lime.

Rock, grey.

conglomerate, gre

$\begin{array}{rr}15 & 15 \\ 30 & 45 \\ 15 & 60 \\ 15 & 75 \\ 19 & 94 \\ 6 & 100 \\ 19 & 119\end{array}$

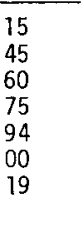

5
4
4
19

$\begin{array}{cc}13 & 13 \\ 13 & 26 \\ 10 & 36 \\ 25 & 61 \\ 18 & 79 \\ 7 & 86 \\ 7 & 88 \\ 5 & 93 \\ 12 & 105 \\ 0.5 & 105.5 \\ 0.5 & 106 \\ & \end{array}$

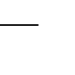

open-hole finish 
APPENDIX A-2 Locations of selected ground-water wells.

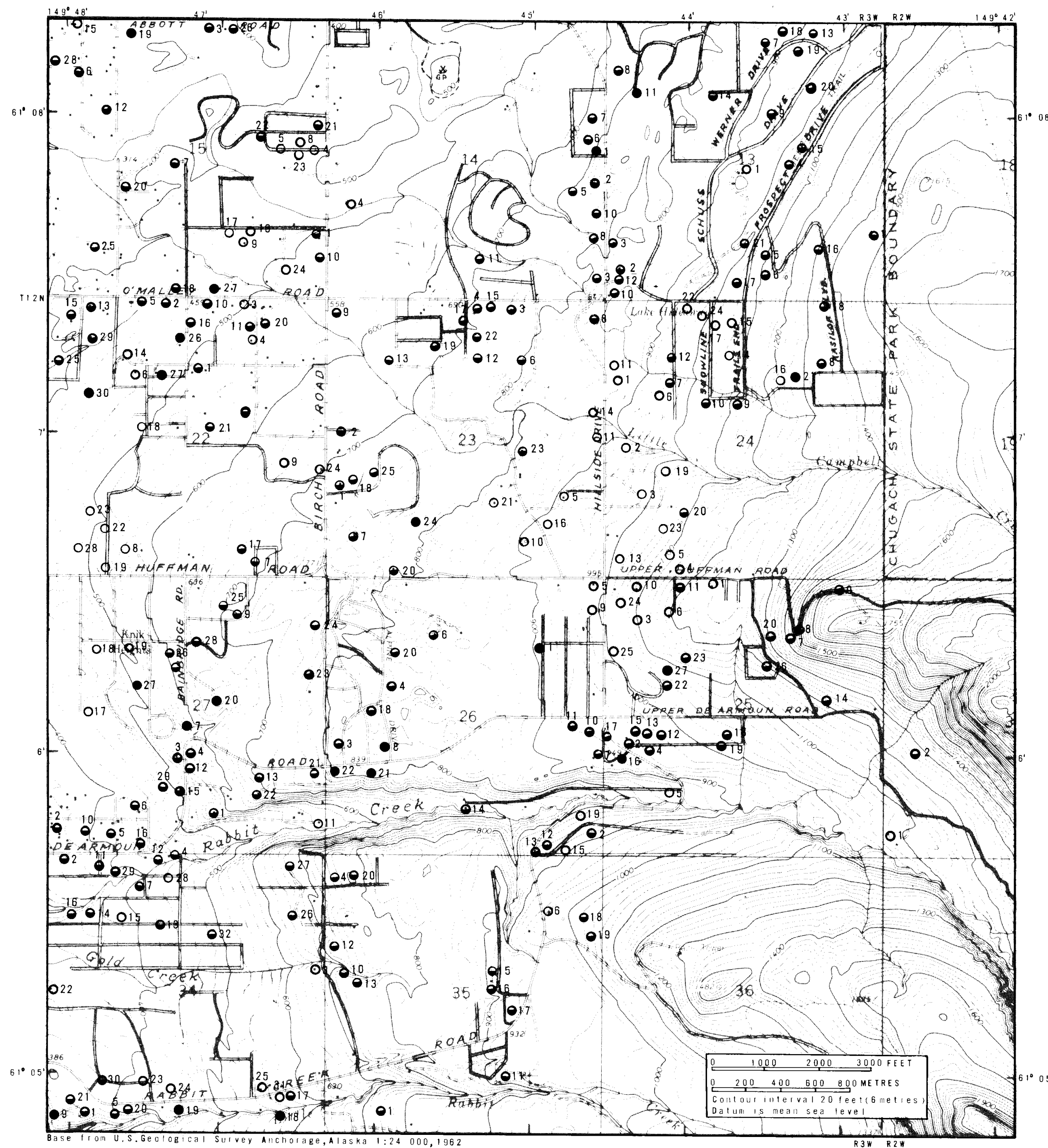

EXPLANATION

Well symbol

O less than 100 feet deep

- 100-250 feet deep

- greater than 250 feet deep
The number beside the well symbol

is a sequential number arbitrarily

assigned within a square mile sec-

system is given in appendix A-3. 
APPENDIX A-3 Reported data on water wells.

\section{Explanation}

Section and map number: Section refers to land line township-range square-mile grid. Map number refers to the sequential listing of wells within square-mile sections (see fig. A-2 for map locations).

Owner: Person responsible for the well at time of original inventory, usually the person who had the well dritled.

Well depth: Maximum depth drilled during construction of the well.

Altitude: Approximate height above sea level of the land surface at the well site.

Aquifer zone and material: Depth to top and bottom of water-bearing strata below land surface and the predominant geologic composition of the aquifer.

Static water level: Depth to water in well below land surface on a specified date after completion of the well.

Pumping data: Yield is gallons of water per minute produced during a test of the well and aquifer performance. B indicates that yield was dertermined by the bailing method. Drawdown is total distance of water level decline from static level at the end of the pumping test. Duration refers to length of pumping test.

Remarks: L indicates that a driller's log is available. LP indicates that the driller's log is given in table A-1. C denotes that chemical analyses of well water are given in table A-4. Chemical data given under remarks were determined in the field and are only approximations.

Note: Nearly a11 wells are completed with open-ended 6-inch casings. Casings of wells producing water from bedrock were usually driven several feet into bedrock with open-hole exposures at greater depth.

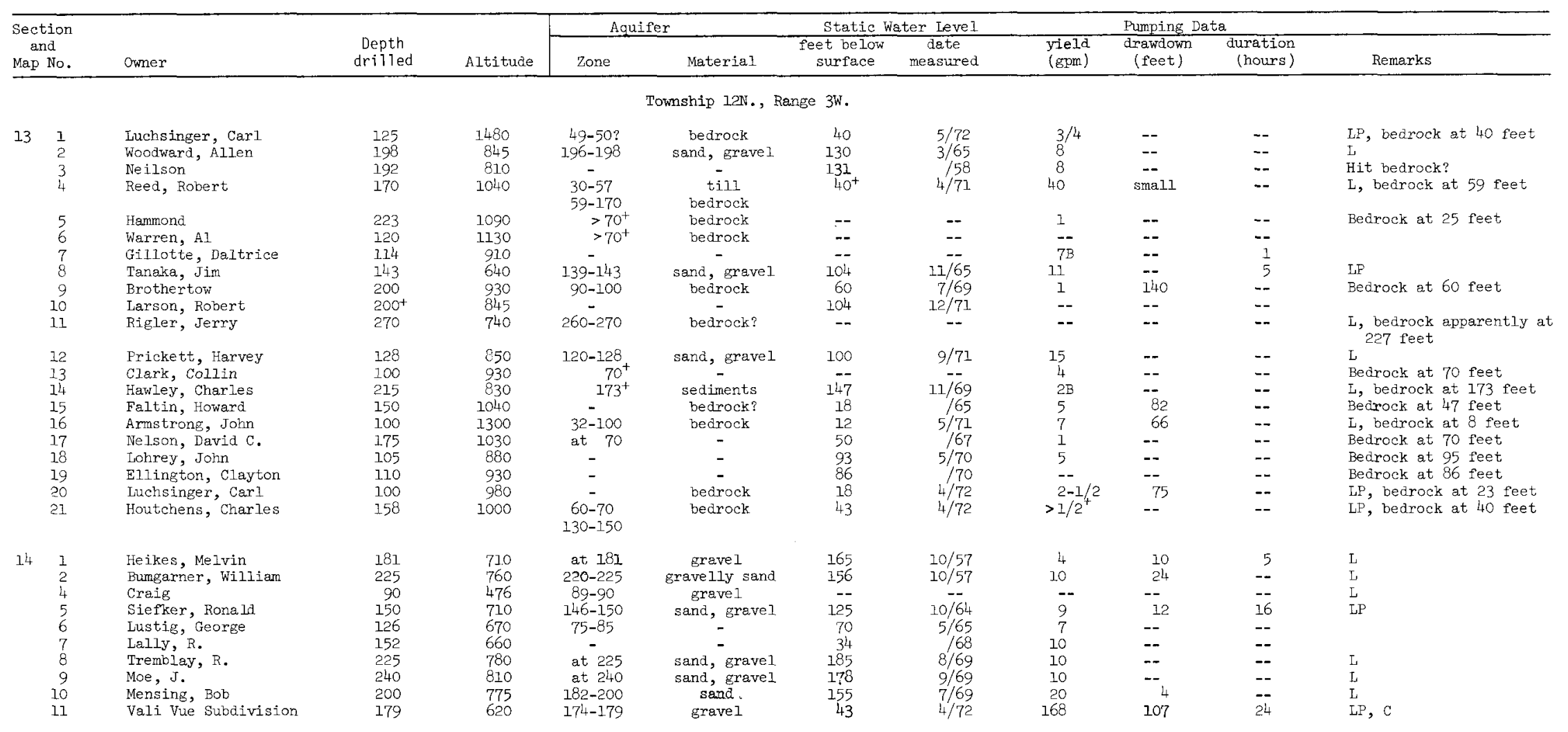




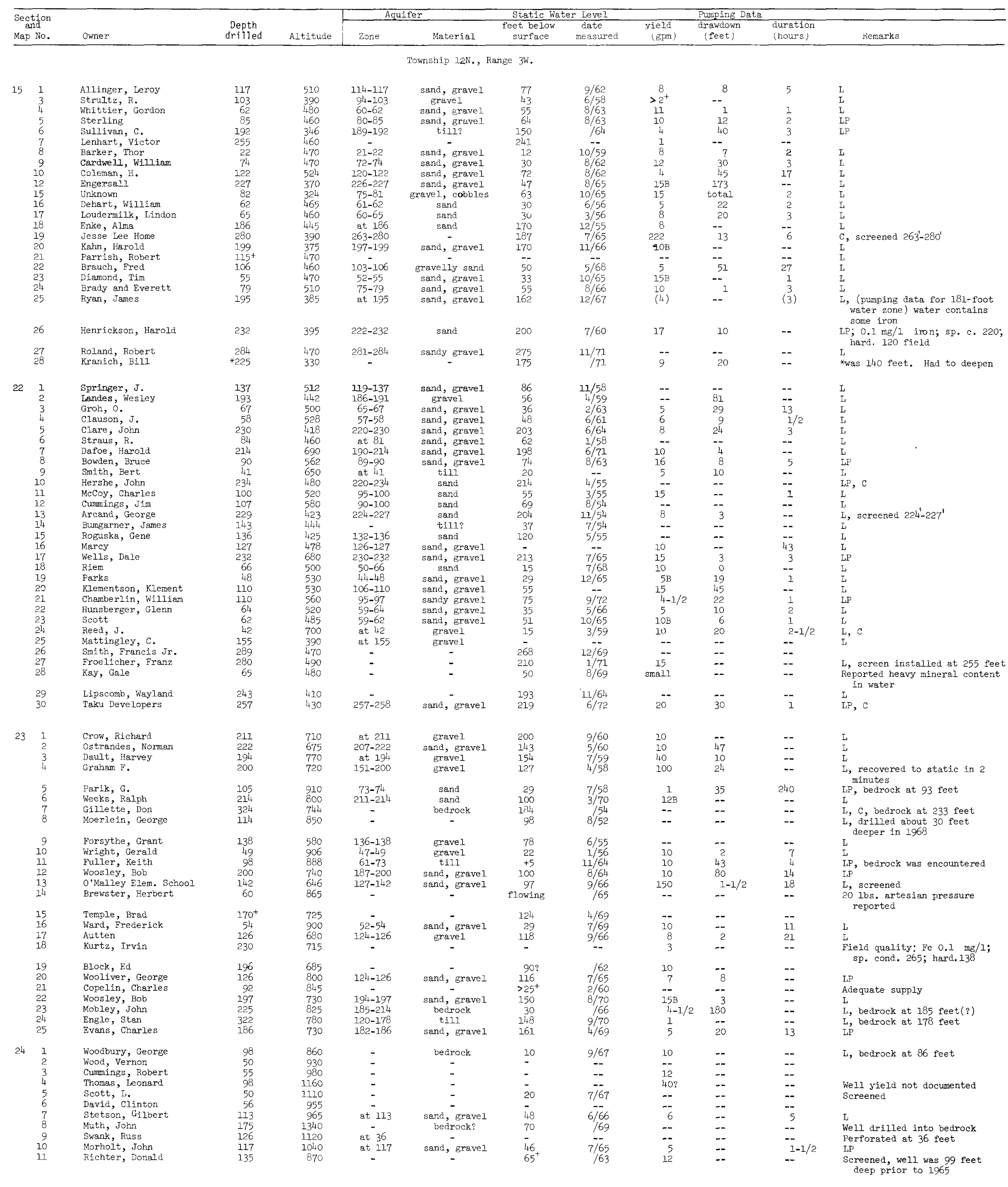

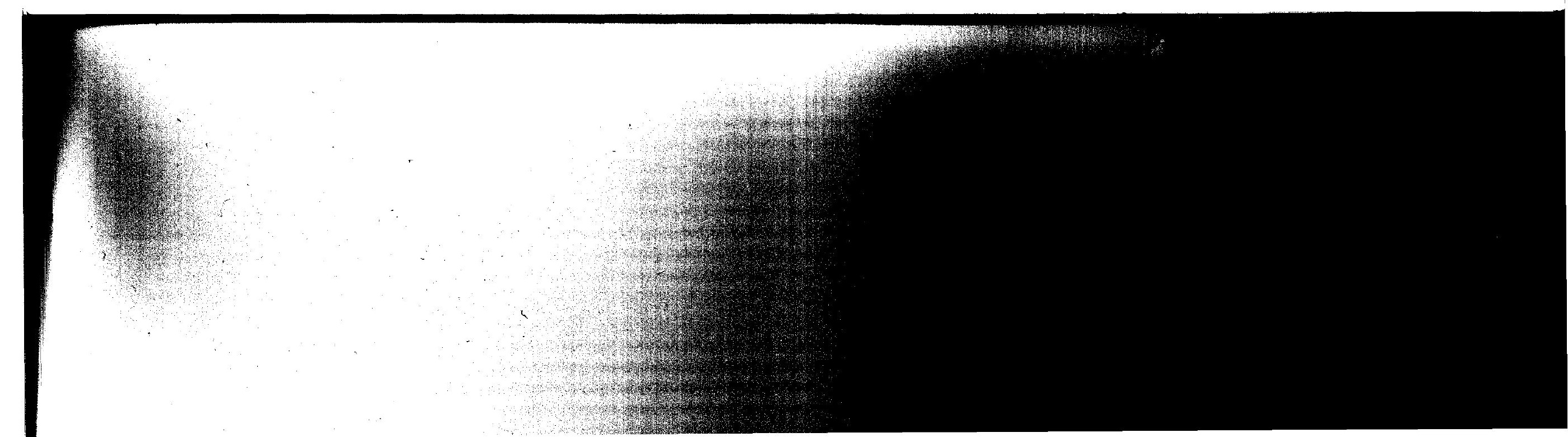


APPENDIX A-3--Continued

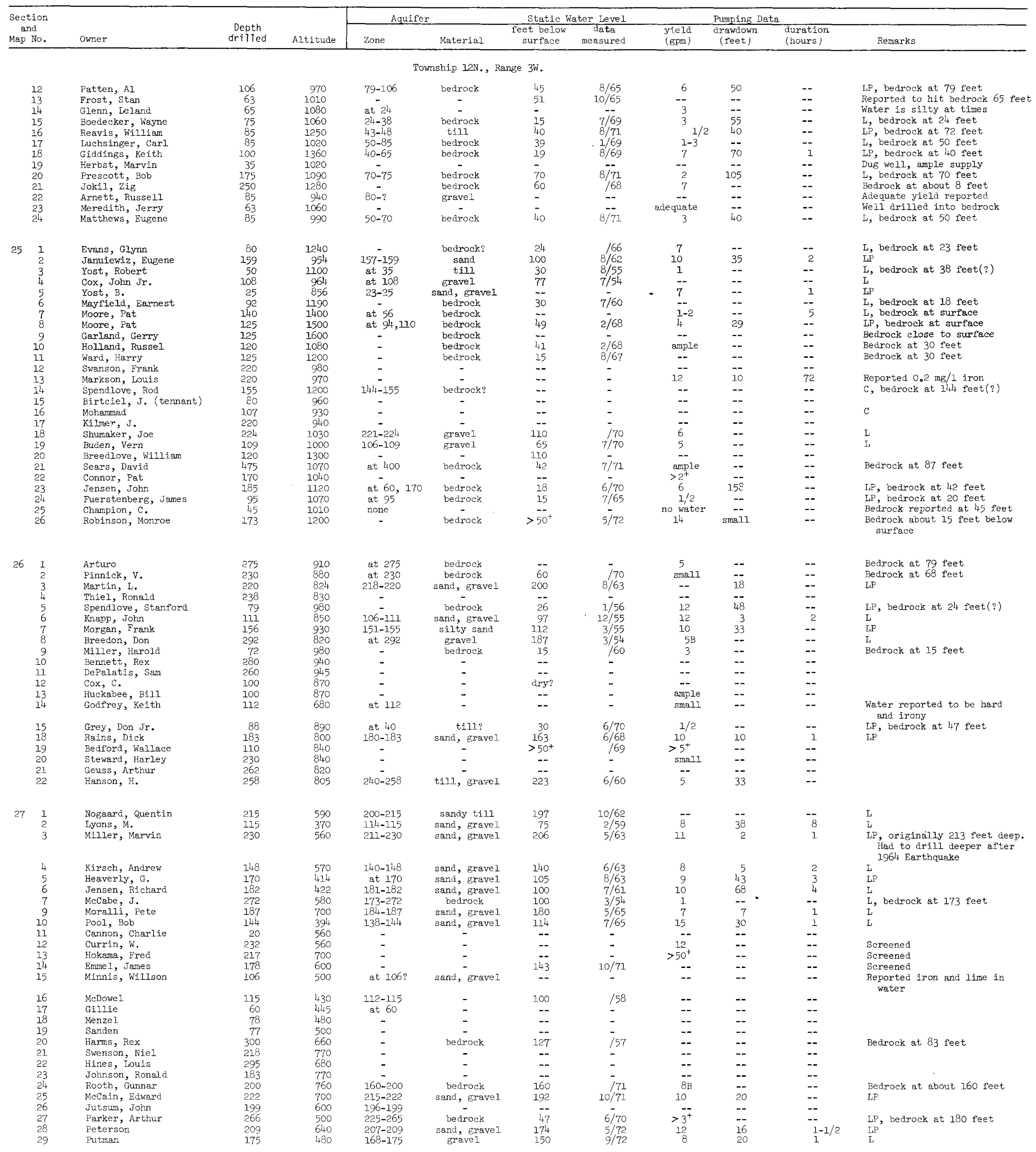


APPENDIX A-3--Continued

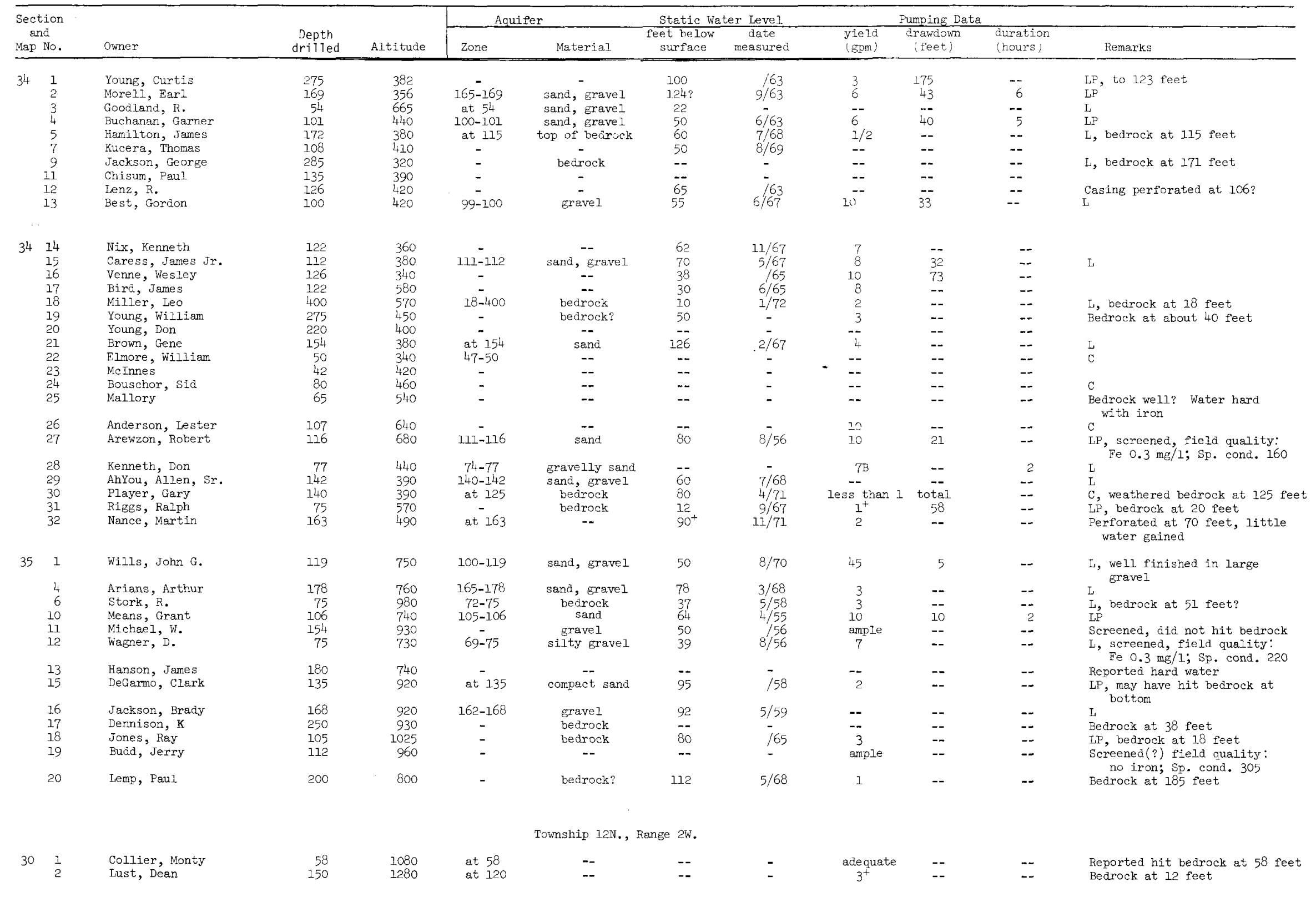

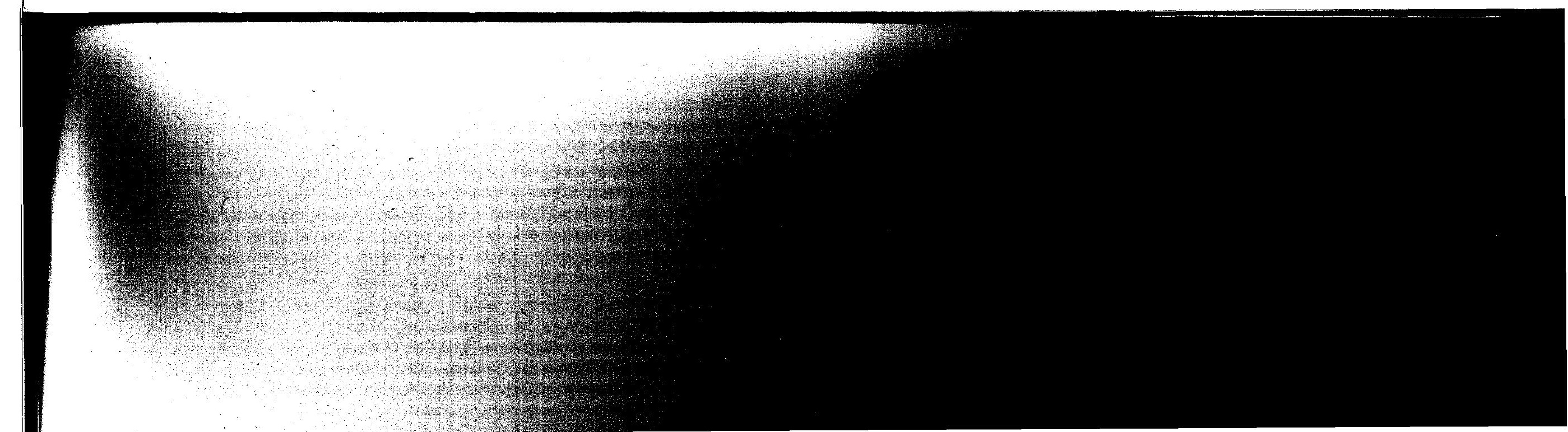


APPENDIX A-4 Chemical analyses of water from wells Location of wells shown in appendix A-2)

\begin{tabular}{|c|c|c|c|c|c|c|c|c|c|c|c|c|c|c|}
\hline \multirow{2}{*}{ Parameter } & \multicolumn{12}{|c|}{ Well designation: Section - number wi thin section } & \multirow{2}{*}{$\begin{array}{l}\text { Recomended } 1 \text { imits } \\
\text { EPA (1972) }\end{array}$} & \multirow{2}{*}{$\begin{array}{l}\text { Significance to domestic and public } \\
\text { water supply users }\end{array}$} \\
\hline & $14-11$ & $15-19$ & $22-10$ & $22-24$ & $22-30$ & $23-7$ & $25-14$ & $25-16$ & $34-22$ & $34-24$ & $34-26$ & $34-30$ & & \\
\hline _Sample date & $4 / 72$ & $8 / 66$ & $12 / 52$ & 150 & $6 / 72$ & $7 / 55$ & $2 / 68$ & $2 / 68$ & $2 / 68$ & $2 / 68$ & $2 / 68$ & $12 / 71$ & & \\
\hline Dept to aquifer ( $f t$ ) & 174 & 263 & 234 & 42 & 257 & $233^{*}$ & $150 *$ & 107 & 47 & 80 & 87. & $125^{*}$ & & $\star *$ Bedrock aquifer tapped \\
\hline Silica $(\mathrm{ma} / 1)$ & 12 & 12 & 20 & 17 & 8.2 & 16 & 9.8 & 11 & 16 & 21. & 12 & 11 & & Excessive amounts may inhibit deterioration of zeolite water softeners \\
\hline Iron $(m g / 1)$ & 0.22 & 0.48 & 1.5 & .08 & .15 & 3.1 & .10 & .06 & .05 & .35 & .14 & - & 0.3 maximum & Excessive amounts cause staininq, unpleasant taste, obiectionable odor \\
\hline Calcium (mg/1) & -35 & 36 & 26 & 9 & 33 & 41 & 42 & 37 & 46 & 28 & 28 & 22 & & \multirow{4}{*}{$\begin{array}{l}\text { In combination with chloride, cause salty taste. In most } \\
\text { waters the concentrations of these ions are too low to affect } \\
\text { use. }\end{array}$} \\
\hline Magnesium (mg/1) & 7.2 & 6.8 & 8.2 & 3.2 & 7.4 & 10 & 5.1 & 12 & 5.3 & 6.1 & 6.1 & 9.6 & & \\
\hline Sodium (mg/1) & 2.9 & 2.8 & 3.2 & $\ldots$ & 3.0 & 18 & 2.5 & 3.5 & 3.7 & 3.7 & 3.0 & 16 & & \\
\hline Potassium (mg/1) & 0.6 & 1.0 & 1.4 & $\ldots$ & 0.9 & 1.2 & 0.4 & 1.3 & 0.7 & 0.4 & 0.7 & 1.0 & & \\
\hline Bicarbonate $(m g / 7)$ & 138 & 150 & 113 & 56 & 129 & 149 & 135 & 180 & 137 & 113 & 112 & 146 & & $\begin{array}{l}\text { Primary component of alkalinity } \\
\text { Excessive amounts cause bitter tast }\end{array}$ \\
\hline Sulfate $(\mathrm{mg} / 1)$ & 9.8 & 0 & 6.0 & $\ldots$ & 8.2 & 40 & 12 & 3.8 & 28 & 14 & 7.5 & 6.5 & 250 maximum & $\begin{array}{l}\text { Excess sve amounts cause bitt } \\
\text { effects } \\
\text { Larae ouantites cause corros }\end{array}$ \\
\hline Chloride (mg/1) & 0.6 & 1.4 & 5.0 & 3.5 & 9.0 & 2.0 & 1.8 & 1.8 & 5.7 & 3.9 & 3.2 & 1.5 & 250 maximum & $\begin{array}{l}\text { Large quantites cause corrosion; with sodium may give } \\
\text { salty taste } \\
\text { Maxiat cecommended consumption varies with temperature }\end{array}$ \\
\hline Fluoride $(\mathrm{m} / \mathrm{ll})$ & 0.1 & 0.1 & $\ldots$ & $\ldots$ & 0 & 0 & 0 & 0 & 0 & 0 & 0 & 0.3 & $2.4 \operatorname{maximum~at~} 50^{\circ} \mathrm{F}$ & 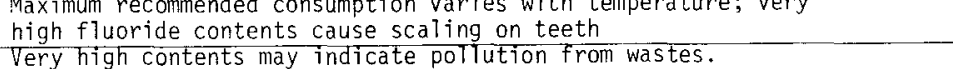 \\
\hline Nitrate $(\operatorname{mg} / 1)$ & 1.5 & $\underline{0}$ & 1.4 & - & 1.4 & 0 & 7.8 & 0.4 & 9.0 & 0.9 & 0.9 & 0.2 & $10 \max$ mimum & $\begin{array}{l}\text { Excessive amounts may cause nitrate poisoning } \\
\text { Excessive amountits may make water unsuitable for drinking }\end{array}$ \\
\hline Dissolved Solids (mg/l) & 138 & 135 & 127 & -- & 128 & 214 & 148 & 160 & 171 & 134 & 117 & 140 & & 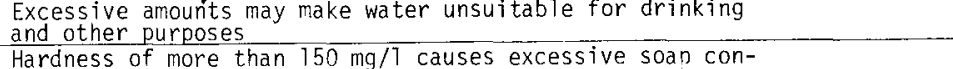 \\
\hline Total Hardness (mg/7) & 121 & 118 & 106 & 36 & 118 & 147 & 141 & 142 & 162 & 113 & 98 & 94 & no 1 imits specifed & 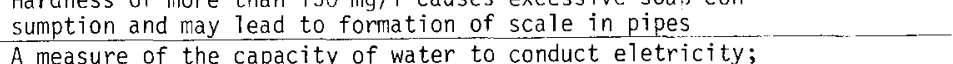 \\
\hline $\begin{array}{l}\text { Specific Conductance } \\
\text { (micrombes at } 25^{\circ} \text { c) }\end{array}$ & 236 & 242 & 192 & 112 & 217 & 337 & 254 & 279 & 280 & 210 & 191 & 241 & & 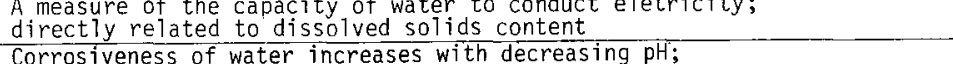 \\
\hline pH & 7.8 & 7.9 & 7.2 & 6.7 & 8.1 & 8.5 & 7.9 & 7.9 & 7.9 & 7.3 & 7.9 & 8.2 & $5.0-9.0$ & 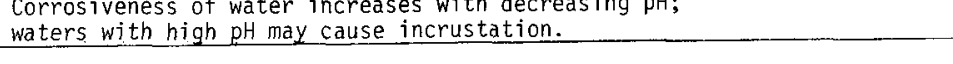 \\
\hline
\end{tabular}




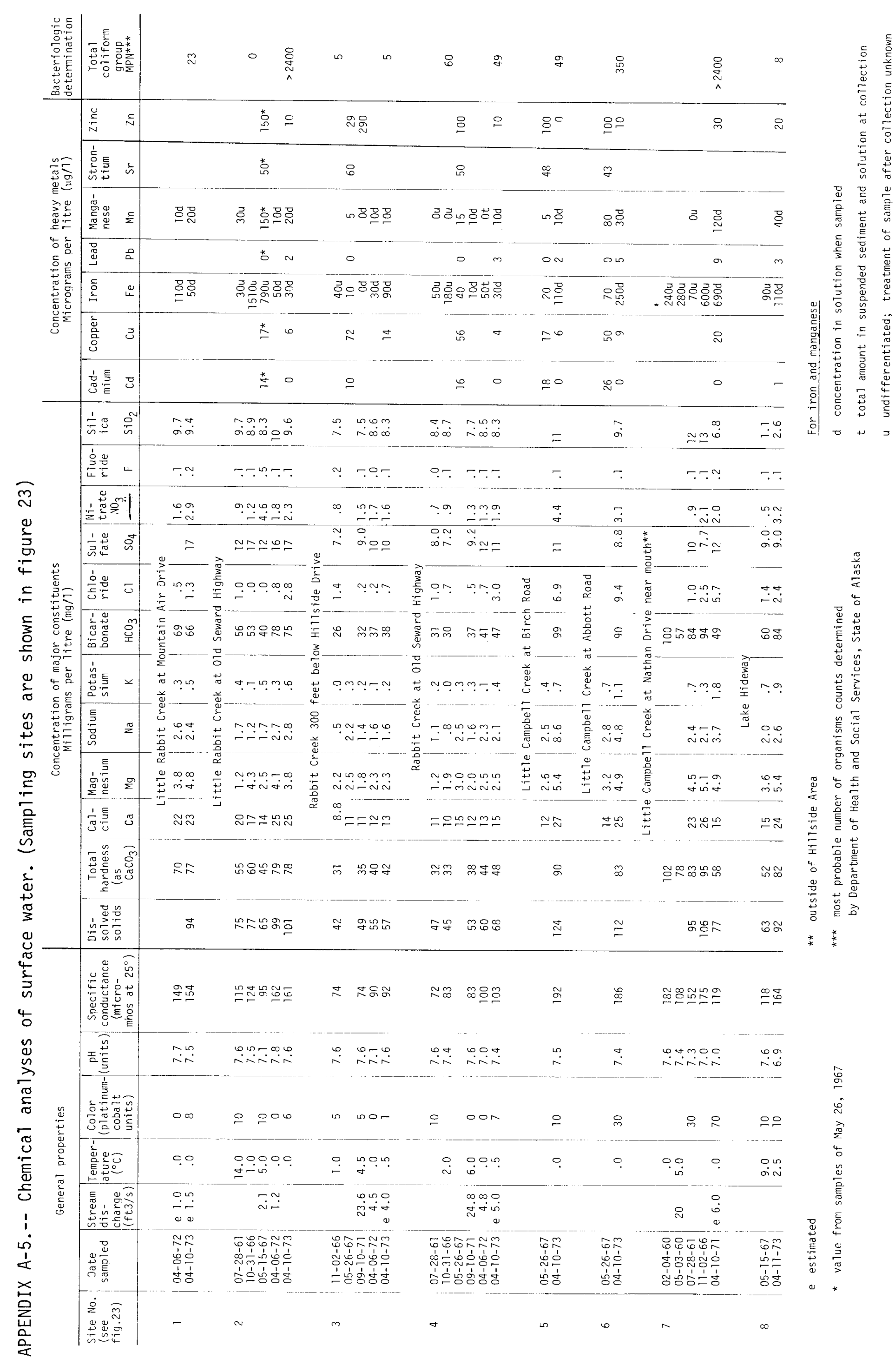




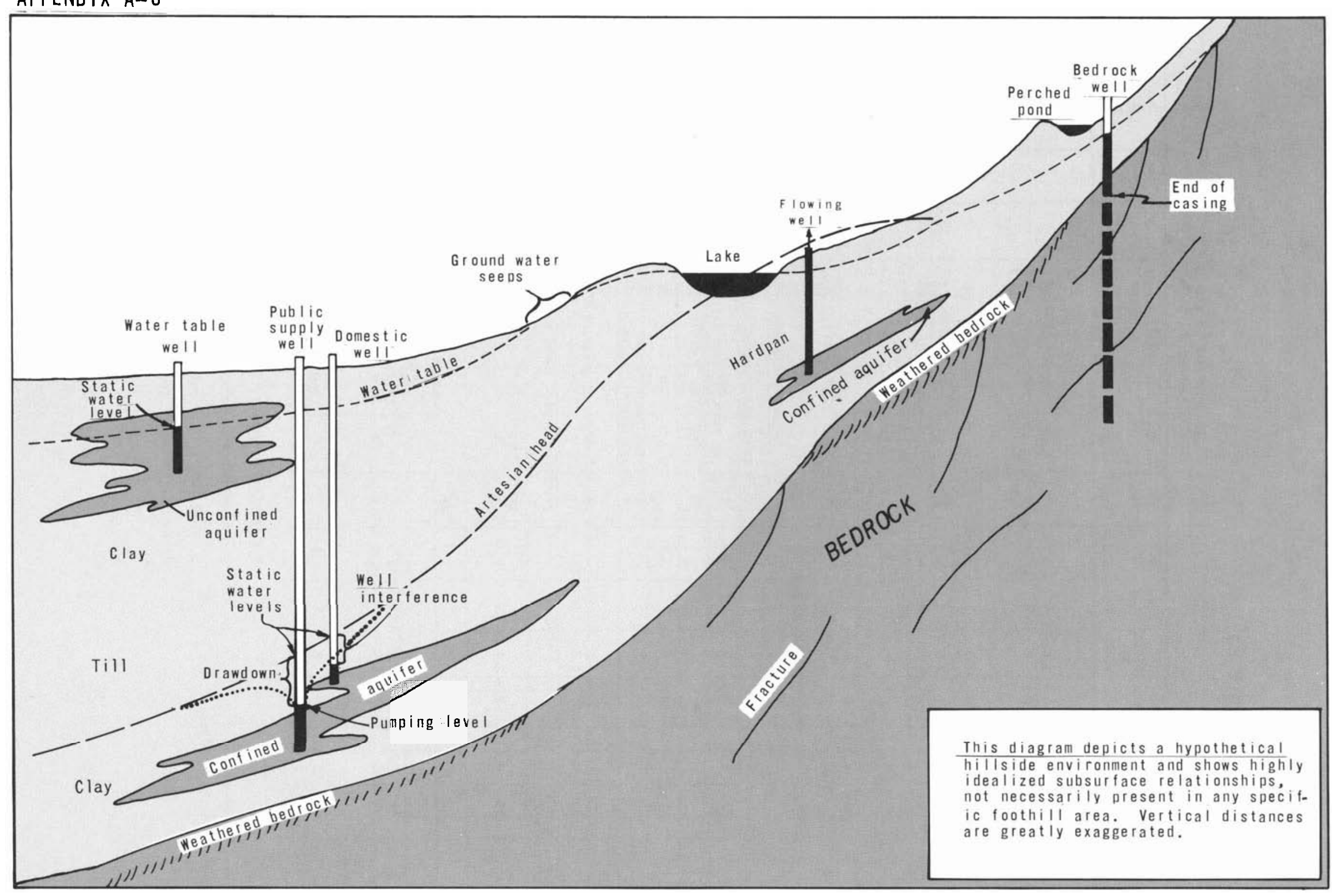

Definition of hydrologic terms as applied to a glaciated foothill environment.

Artesian head - The height above a standard datum (usually mean sea level)
that water will rise in a well tapping a confined ground-water body.

Attenuation - A steady reduction with time in the strength or concentration environment.

Coliform - A grouping of certain bacterial organisms which live in feces or other environments such as soll, water, and vegetation. Coliform bacteria have long been used as indycators of sanitary quatity

Confined aquifer - A water-yielding stratum that is under hydraulic pressure significantiy areater than atmosn sthic. Water in wells tapging confined

Drawdown - The amount of lowering of the natural (or static) water level in

Fecal coliform - A specific group of coliform bacteria that characteristically inhabits the intestines of warmblooded animals and, therefore, are considered indicators of recent fecal pollution if found in water

Flood Dlain - The low-1ying land bordering a stream channel which may be

Hardpan - Locally, a term used to denote unusually compact and very resistant of tough clay with rocks ranging in size from gravel to boulders.

Icing - A localized buildup of ice caused by the continual addition of water Infiltration - The process by which water leaves the land's surface and enters
the soil; thus, vertical penetration of the crust or organic mat is accomplished. Perched ground water - Unconfined ground water which is separated from an a relatively impermeable stratum.
Percolation - The downward (usually vertical) movement of water through Permeability - A measure of the relative ease with which a porous medium can transmity a liquid, ofven a botential aradient. Soils with a high Pumping level
referenced to la lavel of surface. Seep - A wet area on the land surface caused by a general dispersion of nd water which has surfaced.

Sorntive capacity - The ability of earth materials to attract and hold chemical constituents by either molecular adhesion or chemical ion exchange. aranular surface area ner unit volume increases.

Spring - A flow of water from the ground at a point or in a small area springs are differentiated from seeps by their much smaller discharge area. Static water level - The naturally occurrina level, commonty referenced to land surface, of water in a well open to an aquifer. Synonymous with the
nonpurping level in a well, but a static water level may be significantly lowered hy nearby or reqional pumping.

Till - Fragmental unconsolidated material deposited by or from glacial ice Unconfined aquifer $-A$ water-yielding stratum in which ground water is not
subjected to Dressures areater than atmosoheric. The water surface of an Lell interference
Dumbing (withdrawal of lowering of the water leve 7 in a we 11 caused by
onother nearly well. A pumping well produces a cone of drawdown surrounding itse ff; any well inside the horizonta Well log - A descriotive account of the earth materials and drilling
conditions observed during drilling a well. 